НОВАЯ НАУКА

Международный центр научного партнерства
NEW SCIENCE

International Center

for Scientific Partnership

\title{
СОСТОЯНИЕ, ПРОБЛЕМЫ, ПЕРСПЕКТИВЫ РАЗВИТИЯ СОВРЕМЕННОЙ НАУКИ И ОБРАЗОВАНИЯ
}

Монография

г. Петрозаводск

Российская Федерация

МЦНП «Новая наука»

2020 
УДК 001.12

ББК 70

C66

Рекомендовано к публикаџии редакционной коллегией МЦНП «Новая наука»

Под общей редакцией:

Козиловой Лидии Васильевны

кандидата педагогических наук

ФГБОУ ВО "Московский педагогический государственный университет"

Рецензенты:

Ершова Людмила Викторовна

доктор педагогических наук, профессор

ФГБОУ ВО «Ивановский государственный университет»

Чвякин Владимир Алексеевич

доктор философских наук, профессор

ФГБОУ ВО «Московский политехнический университет»

\section{Коллектив авторов:}

Барчо О.Ф., Береславская Н.В., Евграфова О.Г., Жигайлова Л.В., Ильичева В.А., Кузьминова Т.В., Лагунова Л.В., Лапп Е.А., Малоземов О.Ю., Огнева О.Г., Рамазнова Э.А., Рахмонов А.Б., Салимзанова Д.А., Сантуева Э.З., Сахапова Ф.Х., Тронев В.В., Феталиева Л.П.

C66

СОСТОЯНИЕ, ПРОБЛЕМЫ, ПЕРСПЕКТИВЫ РАЗВИТИЯ СОВРЕМЕННОЙ НАУКИ И ОБРАЗОВАНИЯ : [монография / Барчо О. Ф.. и др.] ; под общей ред. Л. В. Козиловой. Петрозаводск : МЦНП «Новая наука», 2020. - 175 с. : ил. - Коллектив авторов.

ISBN 978-5-00174-046-9

В монографии рассматривается круг актуальных вопросов, стоящих перед современными исследователями, обозначается комплекс научной проблематики охватываемых сфер, предлагается новое видение ряда концептов. Издание может быть полезно научным работникам, специалистам-практикам, преподавателям всех уровней образования, интересующимся проблемами развития современной науки и образования.

Авторы публикуемых материалов несут ответственность за содержание своих работ, точность цитат, легитимность использования иллюстраций, приведенных цифр, фактов, названий, персональных данных и иной информации, а также за соблюдение законодательства Российской Федерации и сам факт публикации.

Полные тексты статей в открытом доступе размещены в Научной электронной библиотеке Elibrary.ru в соответствии с Договором № 467-03/2018К от 19.03.2018 г.

УДК 001.12

ББК 70

ISBN 978-5-00174-046-9

(C) Коллектив авторов, текст, иллюстрации, 2020

(С МЦНП «Новая наука» (ИП Ивановская И.И.), оформление, 2020 


\section{ОГЛАВЛЕНИЕ}

ТРАДИЦИИ И НОВАЦИИ В СОВРЕМЕННОМ ОБРАЗОВАНИИ. .5

ПЕДАГОГИЧЕСКИЕ ИДЕИ ЧЕРЕЗ ПРИЗМУ РУССКОЙ ФИЛОСОФИИ С ДРЕВНИХ ВРЕМЕН ДО ЦИФРОВОГО ОБЩЕСТВА

Кузьминова Татьяна Владиславовна

К НЕОБХОДИМОСТИ ИСПОЛЬЗОВАНИЯ ПРИРОДНО-ЭКОЛОГИЧЕСКОГО ФАКТОРА В СОВРЕМЕННОМ ОБРАЗОВАНИИ . 26 Малозёмов Олег Юрьевич, Лагунова Любовь Владимировна

ТВОРЧЕСКИЕ ФОРМЫ РАБОТЫ НАД БИОГРАФИЯМИ КОМПОЗИТОРОВ В КУРСЕ МУЗЫКАЛЬНОЙ ЛИТЕРАТУРЫ КАК СРЕДСТВО ПОВЫШЕНИЯ УЧЕБНОЙ МОТИВАЦИИ СТУДЕНТОВ. ИЗ ОПЫТА РАБОТЫ В ПЕРИОД ДИСТАНЦИОННОГО ОБУЧЕНИЯ 46

Огнева Оксана Григорьевна

ИНКЛЮЗИВНОЕ ОБРАЗОВАНИЕ: ГЕНЕЗИС И ПРОБЛЕМЫ ВНЕДРЕНИЯ В

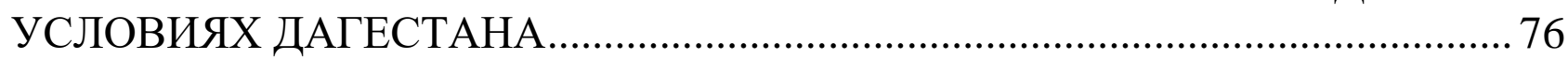

Феталиева Лаура Платовна, Рамазнова Эльмира Алиевна,

Сантуева Элен Зайдхановна

МЕТОДОЛОГИЧЕСКИЕ ОСОБЕННОСТИ СОВРЕМЕННОГО ОБРАЗОВАНИЯ .93

МЕТОДОЛОГИЯ ОЦЕНКИ КООРДИНАЦИОННЫХ СПОСОБНОСТЕЙ ЗАНИМАЮЩИХСЯ СПОРТИВНОЙ ГИМНАСТИКОЙ НА ЭТАПЕ НАЧАЛЬНОЙ ПОДГОТОВКИ .94

Береславская Наталья Вадимовна, Жигайлова Лариса Валентиновна, Барчо Ольга Федоровна, Тронев Вячеслав Вячеславович

МЕТОДИЧЕСКОЕ ОБЕСПЕЧЕНИЕ РЕАЛИЗАЦИИ МОДЕЛИ ПРОФИЛЬНОЙ ПОДГОТОВКИ ПЕДАГОГА-ДЕФЕКТОЛОГА К РАБОТЕ С ДЕТЬМИ С ЗАДЕРЖКОЙ ПСИХИЧЕСКОГО РАЗВИТИЯ 108

Лапп Елена Александровна

ДИФФЕРЕНЦИРОВАННЫЙ ПОДХОД К ОБУЧЕНИЮ БАЛАНСОВЫХ ЭЛЕМЕНТОВ СПОРТИВНЫХ АКРОБАТОК, СПЕЦИАЛИЗИРУЮЩИХСЯ В ЖЕНСКИХ ГРУППОВЫХ УПРАЖНЕНИЯХ 132

Ильичева Виктория Андреевна, Жигайлова Лариса Валентиновна, Береславская Наталья Вадимовна, Тронев Вячеслав Вячеславович 


\section{МЕТОДЫ И ВОЗМОЖНОСТИ}

\section{ДИСТАНЦИОННОГО ОБРАЗОВАНИЯ}

О НЕКОТОРЫХ АСПЕКТАХ ПРИМЕНЕНИЯ ДИСТАНЦИОННЫХ ТЕХНОЛОГИЙ В ПРАКТИКЕ ОБУЧЕНИЯ АНГЛИЙСКОМУ ЯЗЫКУ СТУДЕНТОВ НЕЛИНГВИСТИЧЕСКИХ НАПРАВЛЕНИЙ ПОДГОТОВКИ 146

Ольга Геннадьевна Евграфова, Диляра Айратовна Салимзанова, Фарида Ханифовна Сахапова ОРГАНИЗАЦИОННО-ПЕДАГОГИЧЕСКИЕ УСЛОВИЯ РАЗВИТИЯ ДИСТАНЦИОННОГО ОБРАЗОВАНИЯ. 158 Рахмонов Азизхон Боситхонович 


\section{ТРАДИЦИИ И НОВАЦИИ В СОВРЕМЕННОМ ОБРАЗОВАНИИ}


УДК 37(091)

\title{
ПЕДАГОГИЧЕСКИЕ ИДЕИ ЧЕРЕЗ ПРИЗМУ РУССКОЙ ФИЛОСОФИИ С ДРЕВНИХ ВРЕМЕН ДО ЦИФРОВОГО ОБЩЕСТВА
}

\author{
Кузьминова Татьяна Владиславовна \\ д.э.н., профессор \\ главный научный сотрудник
}

АНОВО «Московский международный университет»

Аннотация: проведен анализ пересечения основных мировых педагогических идей с положениями русской философии. Выявлен тренд развития от сложного к простому: от высшего образования к начальному, от иероглифических языков к алфавитным и т.п. Показано, что русская философия осталась на уровне интуитивного восприятия, более сложного, чем рациональное. Высказано предположение, что соединение современной системы образования с русской философией на основе цифровых технологий позволит решить часть проблем цифрового общества.

Ключевые слова: педагогическая идея, система образования, русская философия, цифровое общество, мировоззрение

\section{PEDAGOGICAL IDEAS THROUGH THE PRISM OF RUSSIAN PHILOSOPHY FROM ANCIENT TIMES TO DIGITAL SOCIETY}

\section{Kuzminova Tatiana Vladislavovna}

\begin{abstract}
: the analysis of the intersection of the main world pedagogical ideas with the provisions of Russian philosophy. The trend of development from complex to simple is revealed: from higher education to primary, from hieroglyphic languages to alphabetic, etc. It is shown that Russian philosophy has remained at the level of intuitive perception, more complex than rational. It is suggested that the combination of the modern education system with Russian philosophy based on digital technologies will solve some of the problems of a digital society.

Key words: pedagogical idea, education system, Russian philosophy, digital society, worldview
\end{abstract}


Система образования является основополагающей сферой деятельности людей по передачи накопленного опыта, знаний и, главное, человеческих ценностей предков потомкам. Проведенный на рубеже XVI-XVII вв. жестокий эксперимент падишаха Акбара, который отобрал у матерей разных национальных новорожденных детей, разместил их в отдельных комнатах без окон и заставил ухаживать за ними глухонемого слугу, показал, что без общения с другими людьми рожденный человеческими родителями малыш сам стать человеком не может.

«Познание зависит от ступеней социальной общинности людей. Общеобязательность познания имеет не только логический, но и социологический характер. Это определяется тем, что познает не трансцендентальный субъект, не универсальный разум, как учил германский идеализм, а конкретный человек с известной душевной структурой, в зависимости от социальных отношений людей» [1, С. 468-469].

Сложность преломления педагогических идей к русской философии заключается в самой нерациональной сути русской философии, лежащей за пределами логики. Талантливый педагог, знающий и разделяющий русскую идею, так или иначе, за счет личного взаимодействия с учеником, позволит ему прикоснуться к русским ценностям, но массовое образование не позволяет найти и подготовить такое количества педагогов, чтобы можно было обеспечить ими все учебные заведения в первую очередь всеобщей начальной и основной школы, а базовые основы мировоззрения проще всего и чаще всего формируются именно там. Следовательно, нужно искать способ проявления нерационального в рациональном, искать возможность создания педагогических технологий, которые, с одной стороны, могут быть тиражированы в работе учителя, а с другой стороны, обеспечат школьникам возможность прикоснуться к русской идее.

«Никакое a priori само по себе ничего не гарантирует, потому что находится во внечеловеческой, трансцендентальной сфере. Необходимо определить отношение человека к этому a priori» [1, С. 469]. Одним из проявлений трансцендентального в социальном являются символы. Н.А. Бердяев писал, что «символическое сознание выше наивнореалистического сознания, и именно оно открывает путь к подлинным реальностям» [1, С. 549]. В контексте этого для российского образования важно, что символизм находится в поле зрения современной отечественной 
педагогической науки [2-4]. Это позволяет пока рассмотреть педагогически идеи в контексте русской идеи только по сути.

Для анализа педагогических идей до XIX века включительно использованы результаты исследований приват-доцента Московского университета М.М. Рубинштейна 1916 г. [5].

Военно-общественное воспитание в Древней Греции рассматривало индивида как материал для общества; общество не признавало его частных интересов и всецело поглощало его в себя. Единственное, на что здесь необходимо обратить внимание в рамках поставленной задачи - это тот факт, что общество исторически было раньше отдельного индивида и всеобее спасение как составная часть русской идеи по факту является возвратом к истокам, но в обновленном виде. Принципиальное отличие - никого не теряем, «последние станут первыми», Древней Греции это было не понятно. Это остается непонятным и для современных рациональных стран, но имманентно включено в русскую душу. В природе есть естественный символ необходимости спасения всех без исключения. Наиболее умные и талантливые во всех отношениях люди рождаются от генетически далеких друг от друга родителей.

В условиях, когда огромное количество людей проявляет свои далеко не лучшие качества и добавляют зло в этот мир, такое положение принимается с трудом. Иеромонах Корнилий (Морозов) в интервью православному каналу «Союз» сказал по этому поводу, что «человек может жить очень неправедно, но образ, пусть затемненный, пусть закопченный (подобно тому, как иногда тускнеет икона) в нем все равно остается. И приходится прикладывать немало усилий, чтобы очистить, убрать налет, накипь с человека, чтобы в нем заново воссияло подобие Божие. Но образ в нем, безусловно, никогда не исчезает» [6]. Очень глубоко эта же тема раскрыта в художественных произведениях Ф.М. Достоевского, которые признаются его философским наследием.

Путь к обновленному состоянию человечества лежит через развитие индивида, начался с софистов и Сократа и не закончился до сих пор. Это глобальный тренд, на который накладывается множество локальных, где приоритет развитию личности периодически уступает место приоритету развития общества. Обновление общества как единого целого связано с достижением каждым индивидом некоторого минимального уровня, необходимого для перехода всего человечества на новый уровень развития. 
С появлением внимания к личности появляется и идея образования, тогда как ранее достаточно было лишь воспитания. Сначала противоречащие между воспитанием и образованием незаметно, но потом приобретает глобальные масштабы. На уровне философии - это противоречивое единство материализма и времени (образование) и идеализма и вечности (воспитание).

С устремленностью русского народа к Граду Грядущему перекликаются педагогические идеи древнегреческого философа Платона. «Платон является педагогическим пророком - прозорливцем, предвосхитившим большую часть основных педагогических идей. В его лице история как будто формулировала те идейные задачи, которые должно было выполнить человечество в своем историческом развитии в области педагогики» [5, С. 28]. Взаимосвязь педагогики с философией древние греки прекрасно понимали. Чтобы учить необходимо сначала определиться с тем, чему учить, а потом уже - как учить. Сначала необходимо определиться с мировоззрением.

В истории греческой философской мысли, посвященной вопросу о сущности и строении мира, выявились два противоположных взгляда на вселенную.

1. Полное недоверие к тому знанию, которое дают человеку его чувственные восприятия.

2. Смена и движение лишены всякой действительности, это обман, порождаемый нашими чувствами.

Эти противоположные учения претворяются у Платона в оригинально примиренное единство. Платон учит, что обе идеи истинны, но они говорят о разных мирах и на самом деле не только не противоречат друг другу, но взаимно пополняют друг друга [5, С. 30]. Здесь мы сталкиваемся с историческим приоритетом диалектической логики над формальной аристотелевской.

Учитывая, что противоречие между образованием и воспитанием в Древней Греции не могло еще себя проявить, Платон считал, что доброе и прекрасное неотделимы друг от друга, как оба они неотделимы от истины. «Эта вера дала Платону возможность и право, которого к нашему горю у нас нет (мнение М.М. Рубинштейна - прим. авт.), право требовать всестороннего гармоничного развития человека, возможности согласованности путей истинного эстетического, этического, интеллектуального и религиозного воспитания. Чтобы понять всю силу этой идеи и для педагогики, достаточно вспомнить, в какую бездну тяжких противоречий и колебаний повергнет нас 
сомнение в возможности совмещения этих путей, необходимых для воспитания цельной личности» [5, С.32].

Категоричность, с которой Платон устремил общество к идеалу, сравнима с фанатичностью, с которой русские коммунисты начали строить новое общество в отдельно взятой стране. «Платона не смущало, что его мир идей существует как бы в отрыве от видимой жизни, он считал, что конфликт между обществом и личностью исчезнет, когда будет найдена абсолютная цель жизни, обладающая одинаково непреложным значением для всех в отдельности и в общем. Чтобы отрезать всякую возможность отложения индивида от интересов общества, Платон на вопрос о том, кто должен воспитывать, ответил радикальным уничтожением семьи и собственности и передал все функции Органа воспитания обществу» [5, С.35-36].

В рамках современного взгляда на триаду «истина - красота - добро» истине (точнее - рациональной справедливости) соответствует рациональность (Запад), красоте - эмоциональность (Россия), добру - интуиция (Восток). «Красота спасет мир» - это про Россию. Единение человечества в конце истории будет соответствовать идеалу Платона. Это не означает, что в западных странах нужно учить только праву, в России только прекрасному, а на Востоке непротивлению злу, но это - тренды, на которые должен быть сделан акцент, остальное рассматривается в преломлении в главному. Символично это можно представить так. Запад формирует гармоничного человека по принципу Скд, Восток - скД, в Россия - сКд, где прописная буква - ведущий тренд, строчные - дополнение к нему (в аббревиатурах: C - рациональная справедливость, К - красота, Д - добро). При таком подходе работает правило системы, в соответствии с которым свойства элементов определяются не автономно, а взаимосвязями с другими элементами, только при таком подходе можно говорить о гармонии, такой подход позволяет увидеть общее народов всего человечества. По большому счету главным результатом деятельности Петра I было привнесение рационального в эмоциональную жизнь России, что позволило этой эмоциональности получить новое развитие. Пусть через конфликт, но внешний мир узнал Россию, а Россия внешний мир. Всемирное единение народов обеспечит мировую гармонию. Гармония - это и есть Град Грядущий, к которому устремлен русский народ.

Далее педагогические идеи ушли в сторону реализма Аристотеля и практицизма древнего Рима, и в целом можно констатировать, что вся последующая педагогическая мысль имела рациональный тренд, что повлекло 
ускоренное развитие материального мира (религиозные школы пока не трогаем, к сожалению, они далеко не всегда преследовали чисто духовные цели). Развитие шло по предопределенному пути. В записях, оставленных племенем Майя, есть указание на то, что материальное всего лишь инструмент развития Великого Духа и оно связано с прохождением Земли через луч, исходящий из центра Хунаб Ку.

Философия Аристотеля представляет особый интерес как материальное развитие Платоновского идеализма, Аристотель не отрицал положений своего учителя, но преломил их к реальной жизни (по Н.А. Бердяеву - к примитивному реализму).

«Аристотель как бы спустил платоновский мир на землю, в мир явлений; он лишает мир идей самостоятельного существования и смотрит на них как общие сущности, которыми обладают все вещи и бытие которых неотделимо от бытия отдельных вещей. Мир в понимании Аристотеля становится единым, и познать вещи - это значит вывести их частное существование из той общей сущности, которая неотделима от самих вещей, вывести частное из общего. Ключом к платоновской загадке у Аристотеля служит принцип развития» [5, С. 45]. Но что-то неземное в философии Аристотеля все равно остается и притягивает как напоминание о высшей ценности.

«Счастье в жизни, будет ли оно для людей выражаться в удовольствиях, или в добродетели, или и в том и другом, сопутствует тем людям, которые в избытке украшены добрыми нравами и разумом и которые проявляют умеренность в приобретении внешних благ, в гораздо большей степени, нежели тем, которые приобретают больше внешних благ, чем это нужно, но бедны благами внутренними» [7, С. 455].

Внешние блага, как своего рода орудие - а всякое орудие пригодно для какой-нибудь определенной цели, - имеют предел; избыток их неизбежно приносит обладателям их вред или, во всяком случае, не приносит никакой пользы; всякое же из духовных благ чем более имеется в избытке, тем более оказывается полезным, если вообще можно допустить, что и они представляют собой не только прекрасное, но и полезное [7, С. 456] .

Переход от мировоззрения Платона к мировоззрению Аристотеля классическая иллюстрация возникновения науки из философии. Н.А. Бердяев писал, что «недаром властителем дум был Аристотель, самый наукообразный философ древности» [8, С. 263]. Наука, по мнению Николая Александровича, «не творчество, а послушание, ее стихия - не свобода, а необходимость. Но она 
была ценной ориентировкой в необходимости и священным познавательным послушанием последствиям содеянного человеком греха. Наука по существу своему и по цели своей всегда познает мир в аспекте необходимости, и категория необходимости - основная категория научного мышления как ориентирующего приспособления к данному состоянию бытия» [8, С. 268]. Но при этом русский философ, безусловно, признал в науке Аристотеля философские элементы.

При этом один из наиболее признаваемых представитель русской философии на Западе Н.А. Бердяев допускал, что наука может возвысится до философии. «Нельзя отрицать, что в науке есть философские элементы, что в научных гипотезах бывает философский полет и что ученые нередко бывают и философами» [8, С. 270].

Мировоззрение Аристотеля позволило его венценосному ученику Александру Македонскому завоевать весь мир, правда, после ранней смерти завоевателя этот мир быстро распался, напоминая о том, что все ценности бытия преходящи. Кроме того, остался открытым вопрос: «Стал бы Александр разбивать Гордеев узел, если бы знал, что это приведен его к смерти в молодом возрасте?».

В эллинистически-римский период философские школы удаляются от характера частных замкнутых обществ и приобретают характер, довольно близкий к современным университетам. Это еще одно подтверждение, что образование развивалось от высшей школы к низшей. Такой была Платоновская Академия, школа перипатетиков, учеников Аристотеля, школы стоиков, эпикурейцев, скептиков и т.д. [5, С.67]. Здесь важно заметить, что развал современной российской системы образования также начался с высшего образования, а потом спустился на средний и начальный школьный уровень. Следовательно, возрождение также должно начинаться с высшей школы.

«С появлением христианства земные интересы и тело человека превратились в нечто радикально злое и греховное. Радостному мироутверждению грека христианство противопоставило непоколебимое убеждение в суетности и ничтожности всего земного» $[5$, С. 75,76$]$. Дело в том, что греческая культура, будучи принятой завоевавшим Грецию Римом, в своем дальнейшем развитии по материальному пути в рамках рационального права превратилась в вакханалию распущенности. Материальное развитие, в отличие от духовного, ограничено, и дойдя до своего предела, превращает человека в животное, если человек не найдет в себе силы остановиться в потреблении 
материальных благ и обратиться к духовным ценностям, но последнее всегда более многогранно и, главное, сложнее, чем простое накопление материального богатства. В середине первого тысячелетия до нашей эры на Востоке, в экономически развитой Индии с имманентно присущим ей интуитивным мировоззрением, возник буддизм как сознательное оставление богатства и переход к созерцанию всего сущего, что привело к экономическому упадку, но вакханалии распущенности не было. В середине первого тысячелетия нашей эры рациональное мышление в Западной Римской империи привело к ее падению. Эмоциональное мировоззрение России в это время находилось в латентном состоянии и еще много столетий не будет показывать себя миру.

«Необъятное педагогическое значение первоначального христианства заключается в том, что оно противопоставило общественному разложению кристальную чистоту своих стремлений, свою непоколебимую веру в правду, в духовную жизнь, в искру Божью в человеке, в сиу нравственно-религиозной чистоты» [5, С. 77]. При этом монастыри стали научными центрами, где массового переписывались книги, которые там же и хранились. Первоначально это привело к сокрытию знания, что не могло не отразиться на педагогике, в дальнейшее отразилось на воспитании, в том числе физическом. Если в Древней Греции был культ красивого, сильно, натренированного человеческого тела, то в средние века начали воспевать страдающее, больное тело.

Уход от одного крайнего полюса (всеобщее падение нравственности) часто приводит к другой крайности (монашество). «Золотая середина», столь ценимая на Востоке - крайне неустойчивое состояние. Неслучайно самой большой тайной, хранимой в библиотеке средневекового монастыря, описанного в романе Умберто Эко «Имя розы» была книга из Придела Африки с записями о том, что Христос смеялся. Смех Бога, воплотившегося в человеке, как источник сомнений, долгие века предавался забвению, что отразилось в воспитательных программах школ, создаваемых при монастырях. Недостаток творчества заменялся спорами о мелочах, названными схоластикой. В общем тренде истории индивидуалистического развития человечества средние века имели локальный тренд приоритета общества над человеком.

«Эпоха Возрождения породила педагогический индивидуализм. Могучий рост индивидуального самосознания выразился не только в критическом отношении к теоретическим основам средневековья, но и в попытках поставить на его место новое независимое миросозерцание» [5, С. 91-92]. Открытие 
Коперником гелиоцентрической системы приводит к пантеизму и смерти на костре Джордано Бруно. Миру возвращается антично-языческая красота.

«Новая педагогика рекомендует воспитывать добродетель целомудрия не из средневековых мотивов очищения души от греховных помыслов, а мотивирует свое требование интересами духовного и физического здоровья и расцвета» $[5$, С. 96].

Реформация начала XVI в., основанная на идеях М. Лютера и его более сурового последователя Ж. Кальвина, вызвала ответную реакцию, был создан иезуитский Орден св. Игнатия, который существует до сих пор. С точки зрения педагогики наиболее интересны иезуитские школы, дававшие широкое образование при жестких ограничениях в рамках католических норм. Ярчайшим представителем иезуитской школы явился Рене Декарт. Консерваторы, боровшиеся против нового церковного течения протестантизма, дали инновационную педагогическую идею о необходимости подготовки учителей.

Сам протестантизм с легкой руки немецкого ученого М. Вебера часто связывают с началом развития капитализма и обозначают как один из важнейших факторов его появления. Протестантизм предложил трудовую этику, в соответствии с которой близость человека к Богу определяется количеством накоплений, сделанных им за счет трудовой деятельности в течение жизни. М.Вебер предположил, что именно это привело к появлению капитализма. Тезис Вебера практически сразу же нашел как своих поклонников, так и критиков. Исследования, проведенные на кафедре философии религии и религиоведения философского факультета МГУ им. М.В. Ломоносова, показали, что исторические факты противоречат тезису немецкого ученого [9].

При общем признании факта влияния религии на развитии экономики однозначным и линейным это влияние не является. Например, после поражения Швеции в войне с России в 1721 г. она превратилась в изолированную протестантскую страну, но не смогла встать на путь экономического развития до тех пор, пока не вошла в Британский глобальный проект. Только после этого протестантизм проявил себя, и то не в плане трудовой этики, а плане высокого уровня грамотности населения, которое позволило ему быстро адаптироваться к новым экономическим условиям. Протестанты заботились о том, чтобы прихожане могли читать Библию, а потому способствовали обучению населения грамоте. Как пример влияния религиозного мировоззрения на 
экономического положение верующих еще более интересна индийская религия джайнизм. Она запрещает убийство любого живого существа, включая комара или червяка, что не позволяло людям, исповедовавшим джайнизм, заниматься земледелием, и они занялись торговлей. В результате в настоящее время джайны составляют $0,1 \%$ населения Индии и контролируют $20 \%$ капитала страны.

Развитие капитализма поставило вопрос о всеобщем практическом образовании. Появляются работы Рабле и Монтеня, Т. Мора и Бэкона, либеральные ценности являются основой педагогики Дж. Локка и Фенелона [5, С. 121-136, 163-170].

До сих пор в поле зрения педагогики остаются идеи Я.А. Коменского. Имея трудную биографию, поставив в основу своей жизни безусловный приоритет служения обществу над личной жизнью, «он всю жизнь верил в человека, который должен жить и действовать достойным своего Творца образом. Этим он ясно определили место педагогики как первостепенного фактора в жизни человечества: она служит выявлению человека. И хотя последняя цель лежит за пределами этой жизни, это - вечной покой во Христе, - но этим не исключается жизнь в земном мире, она становится прямо необходимой» [5, С. 140].

Русской идее отвечает только устремленность к покою во Христе, который у нас называется Градом Грядущим. Обустройство жизни в земном мире является чисто рациональным отношением к бытию и не свойственно русской идее в ее окончательном варианте. Н.А. Бердяев писал, что «Московский период был самым плохим периодом в русской истории, самым душным, наиболее азиатско-татарским по своему типу, и по недоразумению его идеализировали свободолюбивые славянофилы» [1, С. 161]. Характерно, что при чтении книг советского исторического романиста Дмитрия Балашова из цикла «Государи московские» явно ощущается любовь автора к Ивану Калите и его детям, он трогательно описывает их глубоки внутренние переживания и фактически оправдывает жестокость с целью создания сильного государства, но благородный тверской князь Святой Михаил и его свободолюбивые потомки все равно вызывают большее восхищение, поклонение и бесконечную печаль.

Вернемся к великому педагогу Я.А. Коменскому. Его наиболее важным трудом является «Великая дидактика». Главной идеей труда является экспериментальный метод, до сих пор применяемый педагогической психологией. «В этом обещании Коменского слышится утопическая мечта 
сделать педагогическое дело свободным от случайной зависимости от дарований отдельных педагогов. Коменский забыл о значении личности учителя» [5, С. 141-142]. Но при развитии массовой школы это важно, поэтому идеи Коменского до сих находят отклик в педагогике.

В современной российской начальной и основной школе делается акцент на одном из положений Коменского, что все должно проходить без принуждения и без лишних наказаний, что, например, в системе московского образования приняло гротескные формы. Однако при этом забывают, что сам великий педагог писал, что «употребительная в Богемии пословица: «школа без дисциплины - мельница без воды», совершенно верна. Ибо если от мельницы отвести воду, то мельница остановиться» [10, С. 231].

«Хорошо, если образователь юношества узнает: а) цель (зачем?), б) материал (когда?) и в) форму (как?) школьной дисциплины. Цель. Школьную дисциплину следует применять к ученикам, которые вышли из общей колеи школьной жизни. Не ради, впрочем, сделанного проступка (ибо совершившегося нельзя сделать не совершившимся), но ради того, чтобы в подобных же случаях впоследствии предупредить проступок. Материал. Более строгие дисциплинарные меры следует применять не ради занятий и науки, но в видах нравов. Форма. Наилучшую форму дисциплины представляет нам солнце небесное, которое дает развивающимся существам: 1) постоянно свет и тепло, 2) часто дождь и ветер и 3) редко молнию и гром, хотя и это последнее также с целью пользы» [10, С. 231-234].

С точки зрения педагогики большое значение имеет период Руссо с идеей самораскрытия человека, Песталоцци с идеей народно - трудовой педагогики, и Канта с идеей самодеятельно личности [5, С. 170-186; 193-214]. Период совпадает с эпохой французской революции (конец XVIII - начало XIX вв.) рубеж между новой и новейшей педагогикой. Индивидуализм в педагогике принимает свои высшие формы, не обращая внимания на проблему теоретического обоснования демократии в виде парадокса Кондорсе.

Наибольше сопротивление в европейском обществе XVIII в. вызвали религиозные взгляды и педагогические идеи Ж.Ж. Руссо. Он категорически выступил против существующей организации жизни, что сближает его с русским максимализмом, вызванным устремлением русского народа к концу истории. Но, в отличие русского мировоззрения, ему была чужда глубокая эмоциональность. Всю жизнь Руссо скитался и мечтал об уютном семейном тепле, но сам был не в состоянии создать свой дом. Своих детей он отдал в 
сиротские дома, полностью утеряв с ними какую-либо связь. Педагогика Руссо основана на его собственном неудачном опыте домашнего учителя, в качестве цели жизни он определил счастье, гармонично уживающееся в силу простоты и естества с добродетелью. Широкая противоречивость Руссо, опять же напоминающая русскую душу, не оставила его в покое даже после смерти.

«В 1778 г. Руссо, к концу заболевший манией преследования, умер. Были даже предположения, что он окончил свою жизнь самоубийством. В 1791 г. останки его, как идейного вдохновителя французской революции, были перенесены в Пантеон, а в 1814 г. они были вместе с гробом Вольтера выкинуты толпой на улицу» [5, С. 173].

Часто считали, что идеи Ж.Ж. Руссо близки к идеям Л.Н. Толстого. Но, Н.А. Бердяев отмечал, что «Толстой любил Руссо, но не следует преувеличивать влияние на него Руссо. Толстой глубже и радикальнее. У него было русское сознание своей вины, которой у Руссо не было. Толстой менее всего считал свою природу доброй. У него была натура, полная страстей и любви к жизни, вместе с тем была склонность к аскетизму и всегда оставалось что-то от православия. Руссо не знал такого напряженного искания смысла жизни. Руссо требовал возврата от парижских салонов XVIII в. к природе, но у него не было толстовской и очень русской любви к простоте, требования очищения. Огромная разница еще в том, что, в то время как Руссо не остается в правде природной жизни и требует социального контракта, после которого создается очень деспотичное государство, отрицающее свободу совести, Толстой не хочет никакого социального контракта и хочет остаться в правде божественной природы, что и есть исполнение закона Божьего» [1, С. 271].

Если связующим звеном между русской идеей и рациональным мировоззрением являются И. Кант и Г. Гегель, то с интуитивным Востоком это связь идет через мировоззрение Л.Н. Толстого. Нужно отметить, что классификация мировоззрений на рациональное, эмоциональное и интуитивное является отличной от общепринятого в науке деления философии на материализм и идеализм. В линейном делении философии на материализм и идеализм русской идеи нет. Диалектика у Г. Гегеля идеальна, у К. Маркса она материальна, но это одна и та же диалектика, и только в тоталитарности русского коммунизма есть отголосок русской идеи.

Дальнейшее развитие педагогических идей Европы ничего нового с точки зрения их преломления к русской идее не приносит. Но несколько нужно 
задержаться на идее педагогического позитивизма Г. Спенсера, имеющей крайне положительное значение для развития рационального мировоззрения.

Г. Спенсер взглянул на мир как на явление и развитие скрытой непознаваемой для нас бесконечной силы или абсолютного начала. Люди, по его учению, «могут попытаться объяснить только то, что выявилось и развертывается в этом мире. Мир живет в непрерывном процессе расчленения и объединения, этому же закону подчиняются люди и общество. Жизнь заключается в приспособлении внутренних условий внешним без надежды достигнуть когда-либо полного равновесия. В этом приспособлении и заключается жизнь. Спенсер рассматривает различные виды деятельности по степени их жизненной важности. На первом месте стоит самосохранение человека, на втором - добывание необходимых средств для поддержания жизни, пищи, крова, одежды и т.д., далее идет деятельность по воспитанию потомства, к ней примыкают виды деятельности, связанные с поддержанием соответствующих политических и социальных отношений, и наконец, на последней ступени по степени важности стоят виды деятельности, наполняющие досуг жизни, посвященные удовлетворению вкусов и чувств, как служение разным видам искусств» [5, С. 254, 256]. Последовательность важна, обучение происходит только по тем видам деятельности, на которые хватает времени. В современном рыночном мире педагогическая теория Г. Спенсера учит быть конкурентоспособным.

Подобное отношение к воспитанию и обучения четко отвечает имманентной природе рациональных западных народов, ими же используется, а потому способно влиять на другие народы, то есть эффективно взаимодействовать в триаде «рациональность - эмоциональность - интуиция», все глобальные проблемы - результат того, что «интуиция» не имеет той же эффективности, что «рациональность» а Россия, которой предназначено внести во всемирное мировоззрение эмоциональную ноту, тотально «ударилась» в рациональность и забыла о своей идентичности. А, следовательно, и у рационально мировоззрения нет возможности в полной мере соприкоснуться с другими элементами триады и осознать, что все ее элементы являются друг для друга необходимым дополнением.

Современный Открытый Университет Великобритании на весь мир распространил свои управленческие программы, позволяющие эффективно приспособиться к рынку, обучение происходит строго ограниченному количеству инструментов, пусть даже увеличивающемуся от ступени к 
ступени, но все-таки ограниченному, главное - приспособиться к внешнему миру, а потому инструменты ограничены, так как должны быть проверены временем. И обучают там тьюторы, находящиеся также в рамках строго ограниченных методик преподавания, чтобы результат был гарантирован, а ожидаемый результат - определенный уровень материального достатка. Классические критерии рынка - в краткосрочном периоде прибыль, в долгосрочном увеличение стоимости организации, а еще желательно захватить побольше долю рынка, и главный показатель статуса - уровень потребления. Выпускники эффективно взаимодействуют друг с другом, так как работают по одним и тем же правилам, однако мир продолжает катиться в пропасть без равноправных интуитивного и эмоционального мировоззрения. Рациональность предназначена для перевода Духа на новую ступень развития, но без дополняющего интуитивного и эмоционального мировоззрения, она приводит к катастрофе. И ответственность здесь не в меньше степени лежит на народах Востока и России, попавших в информационные сети рациональных ценностей.

«Россия чрезвычайно сильна только у себя дома, когда она отражает нападение, когда сама защищает свою землю от нашествия, но четверть того слабее при нападении» [11, С. 62]. Перефразируя великого мыслителя можно сказать, что России чрезвычайно сильна, отстаивая свою идентичность, но четверть того слабее при замене своих ценностей на чужие.

Мы никогда не будем сильнее западных стран экономически, мы должны стать сильными по-другому, и по-другому, не экономическими методами решить глобальные мировые проблемы. Это не отрицает необходимости иметь жизнеспособную экономику, но она должна стать инструментом отстаивания своей идентичности, а не самоцелью.

Гуманизм, на который опирается английская система образования, ориентирован на срединное равновесие, но это не «золотая середина» Востока, которую можно назвать серединой между бытием и небытием, это - среднее арифметическое близко расположенных друг другу рациональных качеств (неярко выраженного альтруизма и «здорового» эгоизма). В целом весь западный гуманизм срединный, отрицающий стремление человеческой природы к крайним проявлениям. Однако одного стремления к гармонии недостаточно, непоправимой ошибкой является игнорирование естественности крайних проявлений человеческой природы.

Г. Спенсер считал, что жизнь сохраняет строгое соответствие между поступком и наказывающим следствием. Нужно признать, что это наивная 
ложь свойственна всем позитивистам. Если бы это было так, не появилась бы проблема теодицеи, к разрешению которой обращались практически все мыслители. Это очень хорошо понимали русские философы.

Н.А. Бердяев много критиковал гуманизм в той форме, в какой он сложился в века новой истории. «Гуманизм переживает кризис и крах, поскольку он приходит к сознанию самодостаточности человека. Достоевский и Ницше с наибольшей силой обозначают этот кризис гуманизма, этот переход его в антигуманизм, в отрицание человечности. Но мне, писал великий русский философ, самому глубоко присущ религиозный гуманизм, вера в человечность Бога. Это человек бесчеловечен. Бог же человечен. Человечность есть основной атрибут Бога. Человек вкоренен в Боге, как Бог вкоренен в человека» [1, С. 516].

Педагогические идеи в рамках русской философии не успели родиться в силу быстрого окончания периода русского ренессанса начала XX в. Советская педагогика по определению не могла отражать идеи русской нематериалистической и нерациональной философии, так как была под жестким давлением диалектического материализма. Однако, учитывая, что рациональность и материализм являются инструментами развития Духа, в советской педагогике было много полезного, к сожалению, сейчас утерянного.

Жесткая необходимость иметь сильный военно-промышленный комплекс привела к системе образования, из которой выходили сильные физики и математики, владеющие строгой логикой системного анализа. Они же были способны на проявление имманентной эмоциональности, вплоть до парадоксов: создатель водородной бомбы А.Д. Сахаров стал ярым противником войны и борцом за мир. При этом нельзя не отметить, что система воспитания в СССР была пропитана коммунистической идеологией, тотальность которой сродни русской идее, но в своей противоположности повлекшая жесткий запрет на свободомыслие со всеми вытекающими отсюда негативными последствиями. Тем не менее, теория поэтапного формирования умственных действий П.Я. Гальперина, культурно-историческая теория и работы по когнитивному развитию ребенка Л.С. Выготского, теория решения изобретательских задач (ТРИЗ) Г.С. Альтшуллера до настоящего времени востребованы во всем мире. Интересно, что ТРИЗ настолько рационален и не соответствует русской идее, что был рассредоточен по всему миру. В Международную ассоциацию ТРИЗ (МАТРИЗ) в настоящее время входит несколько десятков Общественных Организаций ТРИЗ из России, Беларуси, Латвии, Эстонии, Украины, США, 
Перу, Франции, Израиля, Кореи, а также Европейская Ассоциация ТРИЗ [12], большинство из них возглавляются русскими изобретателями, уехавшими из России. Наибольший интерес для современного образования представляет развитие ТРИЗ для детей [13]. До сих пор существует Московский методологический кружок, созданный Г.П. Щедровицким [14] практически одновременно с созданием ТРИЗ, продолжают развивать концептуальное направление ученики С.П. Никанорова [15]. Большой потенциал с точки зрения использования в процессе образования в условиях быстрого развития цифровых технологий, приводящих в появления огромных массивов новой информации, имеют методики обучения В.Ф. Шаталова [16].

Развал СССР и последующие реформы имели множество негативных последствий для населявших его народов, но с точки зрения нашего анализа имеет важное значение один плюс. Открылась возможность вести исследования в философии без советских ограничений, выпуска свободно формируемых газет, журналов, книг, возник широкий интерес к проблеме формирования и выбора мировоззрения [17, С. 145].

Это способствовало появлению еще одного тренда развития образования в условиях глобализации мира, во всяком случае на уровне теоретического обоснования. К рациональному тренду унификации образования на основе либеральных ценностей добавился тренд необходимости учета национальных ценностей в процессе образования и воспитания молодого поколения.

«Тенденция глобализации образования находит проявление в стремлении к формированию единого образовательного пространства с общностью основных подходов и критериев. Однако неолиберальные подходы, будучи теоретической и идеологической базой глобализации, требуют рассматривать национальные системы образования, прежде всего, как элемент рынка и объект рыночной регуляции. Внедрение в образовательное пространство России представлений о потребительском обществе как наиболее человечном типе социальной организации подрывает вековые традиции национальной духовности, которые заключались как раз в противоположном: в стремлении воспитать в обучающихся способность к бескорыстному служению общему благу. Вторжение инокультурных воспитательный моделей представляет серьезную опасность с точки зрения эффективности социокультурного воспроизводства» [18].

«Понимание развития как достижения определенных социальноэкономических результатов, не может служить объективным критерием. В 
данном случае мы скорее имеем дело с навязыванием определенных стандартов, которые далеко не всегда соответствуют ценностям того или иного общества. Это касается и образования» [19, С. 77].

На фоне публикации работ представителей русской философии и активной деятельности по поиску национального пути развития, можно предположить, что история предоставила возможность внедрения русской идеи в образовательное пространство России как неотъемлемой части мирового образовательного пространства.

Практика показывается, что вопреки логике современного образовательного процесса (от простого к сложному), реальность сначала формировалась от сложного к простому: сначала развивается общество, на определенной ступеньке этого развития формируется индивидуальность; высшее образование (Академия Платона) повлекло за собой развитие начального; диалектическая логика (названная так значительно позже) появилась раньше формальной аристотелевской; сложные языки, основанные на иероглифах, появились раньше алфавитных; маленький человек в детстве очень интуитивен, поэтому может воспринимать глубокую мудрость своих предков, изложенную в народных сказках, вырастая в современном мире становиться рациональным логиком, список можно продолжать...

С этой точки зрения русская философия и построенная на ее основе педагогика - наше будущее, потому что построена даже не на интуиции, а на любви, что является вершиной интуитивного познания. Той любви, которая предполагает создание любимому человеку условий, необходимых для его развития.

В списке педагогических идей вплоть до конца XIX нет русских. Возможно, это связано с тем, что русская идея была «заморожена», не отпущена по пути развития от сложного к простому, чтобы максимально быть сохраненной до исторического этапа «цифровизации» человечества, когда развитие созданных человеком технологий максимально проявило возможность исчезновения человечества с планеты Земля как вида [20].

Никакое образование, а оно играет ключевую роль в формировании мировоззрения, в современном мире невозможно без использования цифровых технологий [21]. Но, безусловно, к технологиям нужно добавить и то лучшее, чтобы развито в отечественной педагогике за годы советской власти, включая подходы П.Я. Гальперина и Л.С. Выготского. 
Начинать, с нашей точки зрения, нужно с честного признания того, что мы в начале 90-х годов прошлого века по неразумению, попытались скачком, вопреки диалектики развития, мгновенно оказаться из «социализма» в «капитализме», минуя все промежуточные формы, что попало в наши учебники по обществознанию. А ведь через них формируется мировоззрение нашего молодого поколения.

Так, параграф «Религия и религиозные организации» учебника за 10 класс по обществознанию предваряется цитатой А. Маслоу, где подчеркивается несостоятельность религиозного мировоззрения: «Информация без человеческого понимания подобна ответу без вопроса - она лишена смысла» [22, С. 142]. При этом школьников никто не учит, что вопрос может быть сформулирован по ответу, а сама постановка вопроса может быть знанием или преддверием нового знания. И нет ссылок на нашу историю, когда православие веками успешно поддерживало в народе дух освободителя от нападающих со всех сторон врагов.

Более того, в конце параграфа у школьников формируется неверное представление о мировоззрении одного из крупнейших русских философов Н.А. Бердяева. Из его работы «Духовное состояние современного мира» вырывается фрагмент, по которому можно сделать вывод (и это подчеркивается задаваемыми к фрагменту вопросами), что Николай Александрович выступал против Бога, против христианской Церкви. Да, он действительно писал: «Основная проблема наших дней не есть проблема о Боге, как думают многие, как думают христиане, призывающие к религиозному возрождению, - основная проблема наших дней есть, прежде всего, проблема человека» (эти слова есть во фрагменте, приводимом в учебнике [22, С. 151]). Но замалчивается, что в той же работе известный русский философ, обозначил: «Кризис человека нужно понять внутренне христиански. Только изнутри христианства можно понять происходящее... христианское учение о человеке не было достаточно раскрыто, не было раскрыто в жизни».

Да, безусловное, философия Н.А. Бердяева сложна для понимания десятиклассника, но использование обрезанных по смыслу кусков его текста для формирования неверного представления о его взглядах, как минимум некорректно.

Отличительно чертой цифровизации общества является лавинообразное увеличение объем информации, но у нас есть опыт ее быстрой обработки и успешного освоения в системе среднего образования [23], опыт серьезный, 
основанный не на простом использовании кем-то разработанных программ, а на формировании быстрого мышления на основе проверенных временем педагогических находок. Это позволяет соединить русскую философию и современную систему образования в условиях цифровизацию общества.

\section{Список литературы}

1. Бердяев Н.А. Малое собрание сочинений. - СПб.: Азбука, АзбукаАттикус, 2018. - 672 с.

2. Манасова Г.Н. Педагогический потенциал символов в истории и современной отечественной практике образовательного процесса: Автореф. дисс. ... канд. пед. наук.: 13.00.01. - Ярославль, 2007. - 21 с.

3. Салмина Н.Г. Знак и символ в обучении. - М.: изд-во Московского университета, 1988. - 288 с.

4. Павлов С.В. Символизм развития и содержания сознания. //Грамота. 2012. - № 10. - Ч.1. - С. 132-135.

5. Рубинштейн М.М. История педагогических идей в ее основных чертах. - М., 1916. - 267 с.

6. Беседы с батюшкой. Душа, Дух и тело. 27 июля 2018 г. URL: https://tvsoyuz.ru/peredachi/besedy-s-batyushkoy-dusha-duh-i-telo Дата посещения: 7.11.2020.

7. Аристотель. Политика /пер. с др.-греч. С.М. Роговина. //Законы правителя: в 3-х т. Т.1.- М.: РИПОЛ классик, 2010.

8. Бердяев Н.А. Смысл творчества. Опыт оправдания человека. // Н.А. Бердяев Философия творчества. Смыл творчества. /Приложение к журналу «Вопросы философии». - М.: изд-во «Правда», 1989.

9. Апполонов А.В. Влияние религиозной этики на экономическую деятельность: традиции и современность. /Выступление на Летней школе философского факультета МГУ им. М.В. Ломоносова для учителей истории и обществознания 28 августа 2019 г.

10. Коменский Я.А. Великая дидактика. - СПб,: издание редакции журнала «Семья и школа», типография А.М. Котомина у Обуховского моста, д. № 93., 1875-1877.

11. Достоевский Ф.М. Дневник писателя за 1876 год, май-октябрь //Полное собрание сочинений, т. 23, - Л.: Наука, 1981. 
12. МАТРИЗ URL: https://matriz.org/\%D0\%BE-\%D0\%BC\%D0\%B0\%D1\% 82\%D1\%80\%D0\%B8\%D0\%B7/ Дата посещения: 7.11.2020.

13. По следам ТРИЗ-эксперимента: начальная школа. URL: https://www.trizland.ru/methods/63/ Дата посещения: 7.11.2020.

14. Московский методологический кружок.

URL: https://www.fondgp.ru/mmk/ Дата посещения: 7.11.2020.

15. Никаноров Спартак Петрович. URL: http://spnikanorov.ru/ Дата посещения: 7.11.2020.

16. Виноградов С. Система Шаталова. Годовой курс за 10 часов. //Наука и жизнь, № 2. - 2008. URL: https://www.nkj.ru/archive/articles/12969/ Дата посещения: 7.11.2020.

17. Никаноров С.П. Уроки СССР. Исторически нерешенные проблемы как факторы возникновения, развития и угасания CCCP. - M., 2011. URL: http://spnikanorov.ru/uploads/books/uroki.pdf Дата посещения 7.11.2020.

18. Руденко В.А. Глобализация образования и проблем сохранения ценностей русской культуры //Теория и практика общественного развития. 2012. - № 6. - С. 57-60.

19. Мегатренды мировой политики и их развитие в XXI веке: учебное пособие для студентов вузов /Под ред. М.М. Лебедевой. - М.: изд-во «Аспект Пресс. 2019. - 400 с.

20. Этика и «цифра»: Этические проблемы цифровых технологий. - М.: РАНХиГС, 2020. - 207 с.

21. Кузьминова Т.В. Русская философия в системе образования современного цифрового общества. //The Best Research Practices: сборник статей Международного научно-исследовательского конкурса (8 ноября 2020 г.) - Петрозаводск, МЦНП «Новая наука», 2020. - С. 94-103. DOI 10.46916/12112020-1-978-5-00174-034-6

22. Обществознание. 10 класс: учебн. для общеобразовательных организации: базовый уровень /под ред. Л.Н. Боголюбова. - 3-е изд. - М.: Просвещение, 2016. - 350 с.

23. Школа - студия Шаталова. Официальный сайт. URL: http://shatalovschools.ru/ Дата посещения: 10.11.2020

(C) Т.В. Кузьминова, 2020 
УДК 37.033:037

\title{
К НЕОБХОДИМОСТИ ИСПОЛЬЗОВАНИЯ ПРИРОДНО-ЭКОЛОГИЧЕСКОГО ФАКТОРА В СОВРЕМЕННОМ ОБРАЗОВАНИИ
}

\author{
Малозёмов Олег Юрьевич \\ канд. пед. наук, доцент \\ Лагунова Любовь Владимировна \\ канд. пед. наук, доцент
}

\begin{abstract}
Аннотация. Рассматриваются вопросы, связанные с формированием экологического сознания средствами образования. Показаны связи экологического сознания со здоровьесберегающей деятельностью. На примере таких областей в образовании как естествознание и физическая культура продемонстрированы возможности педагогики по оздоровлению и формированию экологической культуры воспитанников и обучающихся. Одновременно, выявлено противоречие, заключающееся в том, что возможности природно-оздоровительных факторов используются в образовании слабо. В физкультурно-оздоровительной образовательной практике предлагается и обосновывается акцентирование внимания на таковых.

Ключевые слова: здоровьесбережение, экологизация сознания, природно-оздоровительные факторы, физическая культура.
\end{abstract}

\section{THE NEED TO USE THE NATURAL-ECOLOGICAL FACTOR IN MODERN EDUCATION}

\section{Malozemov Oleg Yurievich Lagunova Lubov Vladimirovna}

\begin{abstract}
The issues related to the formation of ecological consciousness by means of education are considered. The links between ecological consciousness and health-preserving activity are shown. On the example of such areas in education as natural science and physical culture, the possibilities of pedagogy for the improvement and formation of the ecological culture of pupils and students are demonstrated. At the same time, a contradiction was revealed, which consists in the
\end{abstract}


fact that the possibilities of natural health-improving factors are poorly used in education. In physical culture and health-improving educational practice, it is proposed and substantiated to focus on such subjects.

Key words: health preservation, ecologization of consciousness, natural and health-improving factors, physical culture.

Обращение к природно-экологическому фактору обусловлено тем, что экологические проблемы служат наглядным эмпирическим материалом, указывающим на необходимость изменений, которые человечество должно произвести в себе, в том числе и в сфере формирования экологического сознания. Многое в сфере физкультурно-оздоровительной деятельности сводится к разработке программ, методик, совершенствованию материальной базы в основном для целей развития двигательной сферы обучающихся. Однако, охрана здоровья как педагогическая проблема предусматривает не только это, но и формирование экологической культуры обучающихся, являющейся фактором их физического и нравственного здоровья, способствующей формированию нравственных правил общения с природой, потребности в её охране и защите [7]. В нашем понимании, экологизация сознания начинается с валеоустановок ресурсного (самодостаточного) типа [1], поскольку они предполагают устойчивую ориентацию на самосохранение за счёт и внутренних природных сил, и внешних благоприятных природных условий.

Реальность свидетельствует о том, что в настоящее время практически во всех сторонах экономической и культурной деятельности человека в его сознании до сих пор имеется представление о «человеческой исключительности» и освобождённости его от подчинения экологическим закономерностям. Широко распространенный тип экологического сознания, базирующийся на таких представлениях, получил название антропоцентризм. В противовес ему экоцентризм характеризуется следующими основными особенностями [2]:

- Высшую ценность представляет гармоническое развитие человека и природы. Человек - не собственник природы, а один из членов природного общества.

- Отказ от иерархической картины мира.

- Целью взаимодействия с природой является максимальное удовлетворение потребностей и человека, и всего природного сообщества. 
- Характер взаимодействия с природой определяется своего рода «экологическим императивом»: правильно и разрешено только то, что не нарушает существующее в природе экологическое равновесие.

- $\quad$ Этические нормы и правила равным образом распространяются как на взаимодействие между людьми, так и на взаимодействие с миром природы.

- Развитие природы и человека мыслится как процесс коэволюции, взаимовыгодного единства.

Данный принцип должен быть заложен в идеологию образования и, в частности, в идеологию естествознания и физкультурно-оздоровительных занятий, иначе существенно удлиняется и усложняется траектория движения учащегося к способу жизнедеятельности, называемому здоровым образом жизни.

До 80-х годов прошлого столетия экологическое образование сводилось лишь к информированию учащихся в области охраны природы. Тогда под экологическим образованием и воспитанием принято было понимать психолого-педагогический процесс, направленный на формирование знаний научных основ природопользования, необходимых убеждений и практических навыков, определённой ориентации и активной жизненной позиции в области охраны природы. Позже произошли изменения в отношении сущности экологического образования. Осознание трагических последствий несоблюдения экологических закономерностей, зависимости жизни и здоровья каждого человека от состояния природного окружения определило две центральные взаимосвязанные экологические проблемы - защиту здоровья человека и сохранение генетического богатства биосферы.

Реальная жизнь показывает, что здоровьесбережение населения, особенно детей и учащейся молодёжи, в урбанизированных регионах нашей страны является одной из самых актуальных проблем. Поэтому в современных условиях государству и обществу необходимо объединить усилия в решении проблемы повышения саногенного личностного и общественного потенциала. Здесь важен комплексный подход, реализуемый как через укрепление физической компоненты здоровья, сохранение и восстановление природноэкологических комплексов, так и путём экологизации сознания, формирования духовного богатства и нравственной культуры каждого человека. Только духовно развитая личность способна бережно относиться к природе. Более того, по словам А.А. Реан [10], поскольку конечной целью любой образовательной системы является не только обучение и воспитание, но и 
развитие личности, то мерой достижения этой цели является результат, находящийся в самой личности выпускника, a не в безличных новообразованиях. Экологические знания беспомощны, если не произошла экологизация сознания, если в образовательном процессе не затронута эмоциональная сфера.

Урбанизация приводит не только к «выталкиванию» детей из природы с последующими проблемами личностного развития, но и наносит подчас непоправимый вред самой природе. Однако в пределах холистического подхода можно говорить о том, что под влиянием экологических проблем происходит переориентация целей общего образования на формирование широкого взгляда на окружающую среду и универсальность человеческого характера вместо традиционного потребительского. Экологические дисциплины становятся частью общего воспитания [11]. Разрабатываются теоретические и методические аспекты естественнонаучного и эколого-валеологического образования [5]. Дисциплины гуманитарного и естественно-технического цикла всё теснее соединяются с экологическим образованием, что обеспечивает образовательному процессу необходимую системность. При этом ориентация на реализацию модели устойчивого развития приближает современную систему образования к объективным запросам времени.

Формирование культуры понимания природы и природолюбия носит комплексный и системный характер. Развитие этого процесса предполагает как разработку и выпуск учебно-методической литературы в рамках образовательного процесса, так и осуществление разноплановых тематических программ и проектов, проведение целенаправленных акций и мероприятий, разработку игровой и другой продукции. Деятельность по формированию культуры природолюбия, по мнению Т.В. Зотовой [3], должна стать основополагающей в работе дошкольных учреждений и школ, так как этот процесс способствует развитию в современном обществе гармоничной личности и, следовательно, формированию нового отношения к природе. Это, в свою очередь, определяет степень экологической культуры детей, подростков и всего населения.

По аналогии с комплексным характером физического воспитания, немыслимым без основного средства - физических упражнений, формирование культуры природолюбия также комплексно, но экологическое образование, рекреация, культура здоровья немыслимы без общения с природой. Ещё в XVIII веке Ж.Ж. Руссо высказал мысль о том, что экскурсии в природу 
развивают творческую наблюдательность, пытливость и самостоятельность в исследовании окружающего мира. Экологическая экскурсия (от лат. excursio поездка) - это форма экологического образования, представляющая собой групповое посещение природных комплексов или учреждений культуры в образовательных и развивающих целях.

Известный педагог-методист К.П. Ягодовский ещё в начале XX века сформулировал основные принципы проведения экскурсий, которые остаются полностью актуальными и сегодня [4]. Во-первых, главная цель всякой естественно-исторической экскурсии должна заключаться не в показе участникам и запоминании ими видов и названий нескольких десятков живых существ, и не в том, чтобы научить отыскивать и описывать морфологические и биологические особенности отдельного животного или растительного организма, а в том, чтобы показать им и научить их видеть жизнь природы, понимать биологические прочессы. Во-вторых, обращать внимание экскурсантов нужно не на отдельный организм, а на явления общего характера, причём отдельные организмы являются только примерами, иллюстрирующими целостное явление. Только при этом непременном условии можно достигнуть того, что экскурсанты будут представлять себе жизнь окружающей природы в виде ряда тесно связанных явлений, а не в виде отдельных существ, отличающихся теми или иными удивительными особенностями.

На экскурсии используется основной метод ознакомления с природой наблюдение, являющийся, по мнению психологов, сложной деятельностью, основу которой составляет сознательное, целенаправленное восприятие. Наблюдение формируется на протяжении всей жизни человека и включает в себя полноту восприятия частей, свойств; тонкость анализа, планомерность интерпретацию, осмысление воспринятого в свете прежнего опыта.

На экскурсиях руководитель должен проводить работу по уточнению и расширению природоведческих понятий, формированию материалистического мировоззрения, развитию логического мышления, воспитанию эстетических чувств, приобретение умения наблюдать в природе. Участники знакомятся с природой во всём богатстве её красок звуков, запахов, форм. На экскурсиях более чётко прослеживается связь явлений между собой.

На экскурсиях можно рассматривать и проблемно-поисковые ситуации. Проблемные ситуации составляют органическую часть процесса познания и находятся в неразрывном взаимодействии с наблюдением, практической деятельностью и объяснением. 
Интересными являются наблюдения за животными и растениями. Растения незаменимый природный барометр, они ошибаются редко. Наблюдения за животными также могут дать много любопытной и полезной информации о состоянии погоды, об ориентировании, о самых различных связях в природе: растения-насекомые; растения-птицы и т.п., об отношениях человека к ним. Из-за отсутствия наблюдательности многие не могут предсказать последствий своего поведения, своего вмешательства в жизни растений и животных и этим наносят значительный вред природным объектам.

Исследовательский подход к изучению природы позволяет на экскурсиях обучать участников ориентироваться на местности, наблюдать мир природы, делать сопоставления, устанавливать связи между наблюдаемыми предметами и явлениями природы, способствуя формированию навыков самостоятельного изучения окружающей действительности. Здесь формируется система представлений о природных комплексах (биоценозах). Экскурсия позволяет в полной мере раскрыть эстетический и познавательный потенциал мира природы, формировать ценностное отношение к нему, осваивать ряд природоохранных технологий и, главное, стратегию индивидуального поведения в природной среде.

Экскурсия начинается с определения природного ландшафта, его краткой характеристики, особенностей в данный сезон года. Обращается внимание на своеобразие и красоту природного пейзажа, отдельных природных объектов. Используются произведения писателей и поэтов.

Успех проведения экскурсий во многом определяется экскурсоводом (инструктором по туризму, краеведом, педагогом и пр.), его мастерством, любовью к природе, чутким отношением к экскурсантам. Обязательна доверительная обстановка во время проведения бесед, только тогда у участников появляется возможность высказать свои мысли, суждения, чувства, что помогает выработке личностного отношения к окружающей природной среде.

Необходимо, чтобы увиденное отразилось и на эстетическом воспитании участников, вызвало у них целостный образ природы (экологическую картину мира), обострило их глаз, обогатило мысль, язык поэтическими образами. Однако многим участникам надо помочь находить эти поэтические краски. С этой целью можно использовать чтение отрывков из художественных произведений, в которых имеются поэтические описания природы, 
философские изречения. Всё это в совокупности повышает экологопознавательный потенциал, формирующий здоровье личности.

Таким образом, экскурсии в природу имеют большое познавательное и воспитательное значение. Они расширяют и углубляют знания, особенно детей и учащейся молодёжи. Участники видят объекты природы в естественной среде, наблюдают взаимосвязь растений с почвой, животных с растениями. Это позволяет сформировать представление о «живой» и «неживой» природе как о едином целом, в котором все части теснейшим образом взаимосвязаны. Только в этом случае знаниевая наполненность личности переходит в эколого-валеологические убеждения, в элементы здорового образа и стиля жизни, а качество жизни неразрывно связывается с природно-оздоровительными факторами, а не с урбанизацией.

Перед учителями школ и воспитателями, методистами ДОУ стоят важные и ответственные задачи: развивать у детей интерес к изучению окружающего мира, разъяснять им основы экологических знаний, а также широко пропагандировать природоохранные мероприятия. Всё это должно реализовываться во время занятий по природоведению, физкультурнооздоровительных, при проведении экскурсий в природу, содержании животных в уголках живой природы и др. Однако, в ходе этой работы нередко обнаруживаются недостатки, заключающиеся в том, что детей и учащихся знакомят чаще всего с высшими животными, описываемыми в книгах и методических руководствах: волк, лиса, медведь, заяц и т.П. Более того, очень часто многочисленные примеры приводятся с животными, не обитающими в нашем регионе: львы, крокодилы, антилопы, бегемоты и др. Данных животных дети практически никогда не видят в природе, они знают о них только по сказкам и многочисленным богато иллюстрированным энциклопедиям, а также при визуальном знакомстве в зоопарке. Таким образом, для детей и учащихся знаниевая составляющая не находит подкрепления в природной среде своего региона. В результате нарушается целостность экопедагогического процесса, что недопустимо в работе с детьми.

С другой стороны, органический мир в современную эпоху в нашем регионе населяют в основном низшие беспозвоночные животные, которые являются фундаментом всей растительной и животной жизни на нашей планете. Беспозвоночные, особенно членистоногие, очень разнообразны, их биомасса намного превышает биомассу позвоночных животных. Исключительное многообразие беспозвоночных животных, разнообразие типов 
их питания и размножения способствует круговороту веществ. Беспозвоночные имеют большое значение как источники пищи для других животных, а также как опылители растений. Многие из них являются паразитами и переносчиками возбудителей болезней человека и животных, некоторые повреждают растения. Однако на занятиях по теме «Животные родного края» детей знакомят, как правило, с позвоночными животными. Гораздо реже приводятся сведения о насекомых, совсем не демонстрируют такие важные группы как моллюски, черви и др.

Все рекомендации природоохранной значимости тоже касаются только птиц и млекопитающих. Например, «нельзя разорять гнезда птиц», но реально дети почти никогда не видят, не находят гнезда в природе, это трудно даже специалисту. Следовательно, нет прямой связи теории с практикой, нет интериоризации знаний, то есть когнитивная компонента личности не закрепляется на поведенческом уровне. В то же время практически нет объяснений, что для сохранения леса (где приятно находиться и отдыхать) очень важны всем известные и часто встречающиеся муравьи. Вряд ли найдётся человек, который ни разу в жизни не останавливался возле муравейника, завороженный удивительным и необъяснимым миром этих насекомых. Сложное и даже, казалось бы, осмысленное поведение муравьев вызывает изумление и восхищение человека уже тысячи лет. Но муравьи приносят ещё и огромную пользу: спасают наши леса от нашествия насекомых-вредителей, разносят семена растений, улучшают качество почвы, насыщая её питательными веществами, служат важнейшей пищей для многих птиц и зверей. Изучение муравьев - полезное и необычайно интересное занятие. Между тем, любой может подойти к муравьиной куче и просто так из любопытства, или по незнанию палкой, ногой расковырять её, нарушив природную гармонию.

Ещё в 1971 году Всероссийское общество охраны природы объявило операцию «Муравей», нацеленную на расселение и охрану муравейников. Это необходимо объяснять учащимся и по возможности привлекать их к выполнению этой важной работы.

В качестве примера можно также рассмотреть всем хорошо известных дождевых червей. Создавая структуру почвы, улучшая её воздушный и водный режим, они обогащают почву питательными веществами. В своё время крупнейший натуралист Ч. Дарвин написал: «Плуг принадлежит к числу древнейших изобретений человека, но ещё задолго до его изобретения почва 
правильно обрабатывалась червями и всегда будет обрабатываться ими. Весьма сомнительно, чтобы нашлись другие животные, которые в истории земной коры заняли бы столь видное место». Это мнение великого натуралиста о масштабах деятельности дождевых червей не было преувеличенным. Позднейшие исследования показали, что влияние деятельности дождевых червей на почву весьма велико и многообразно.

В связи с этим во время экскурсий с детьми полезно собрать некоторое количество дождевых червей для содержания их в уголке живой природы с целью проведения опытов и наблюдений. Детям можно было бы давать самостоятельные задания на дом. Подготовить ответы на следующие вопросы: могут ли дождевые черви жить в сухих и переувлажненных почвах?, какие приспособления выработались у червей в связи с жизнью в почве?, при каких условиях происходит массовое выползание червей на поверхность земли и почему?, почему дождевые черви подлежат охране? и др.

Одними из любимых мест отдыха являются также и наши природные водоёмы. Во время экскурсии на водоём надо знакомить учащихся с многообразием состава моллюсков и водных насекомых, с их биологическими и экологическими особенностями в связи с приспособлением к жизни в воде. Можно и нужно собрать материал для содержания этих животных в аквариуме. Такие экскурсии и содержание животных в дошкольном образовательном учреждении (ДОУ), школе и дома имеют огромное развивающее и воспитательное значение, способствуют пониманию проблемы изучения и сохранения животных родного края.

Важнейшим составным компонентом любого пресного водоёма являются также и одноклеточные животные (простейшие). Они служат главной пищей для червей, ракообразных, рыб, амфибий и других животных. Наблюдение за простейшими под микроскопом - увлекательнейшее занятие для любого человека, тем более для детей. В школах и даже в некоторых ДОУ имеются микроскопы, которые зачастую не используются для изучения простейших, наблюдениями за их образом жизни (движением, питанием, размножением, раздражимостью и т.д.).

Природа является одновременно и одним из основных средств эстетического воспитания детей. Красота природы не оставляет безучастным даже самых маленьких детей. Поэтому именно на природных объектах необходимо учить их чувствовать прекрасное. Так, в наших краях ещё сохранилось немало красивейших бабочек (махаон, аполлон, траурница, 
павлиний глаз, лимонница и др.), но многие из них, к сожалению, стали очень редкими и внесены в «Красную книгу». Необходимо нацеливать детей наблюдать за бабочками, но не отлавливать для коллекций (как это зачастую делалось ранее).

В процессе формирования у детей знаний о взаимосвязи социальных и природных явлений, также громадное значение имеет желание и умение самого воспитателя находить красивое и наслаждаться им, наличие у него собственной экологической культуры. Только в этом случае, владея необходимыми знаниями и умениями, а также необходимыми методами работы, воспитатель или учитель, любящий и понимающий природу, сумеет сделать сё мощным фактором всестороннего развития ребёнка. Нам представляется, что в этом имеются большие упущения в современном образовании в направлении естествознания дошкольников и младших школьников. Педагог может донести учащимся только то, что сам усвоил и освоил практически.

На уровне методологических и практических изысканий подобное уже разрабатывалось в Уральском регионе [11]. Так, в рамках проекта РГНФ № 0406-83607 за 2004/05 годы «Учёт экологических факторов в построении региональных систем образования» впервые проводились исследования на уровне интеграции медицины, экологии и педагогики по выявлению экологических факторов, оказывающих существенное влияние на организацию образовательного процесса и формирование здоровьесберегающей среды жизнедеятельности образовательного учреждения. Выявлены внутренние и внешние экологические факторы, которые не заменяют санитарные нормативы, а значительно расширяют требования к педагогическому процессу и организации среды образовательного учреждения.

Ещё одной из важнейших сторон оздоровления посредством экологизации сознания является вопрос о взаимосвязи экологической культуры и физкультурно-оздоровительной деятельности в рамках реализации образовательного процесса. Как культурный феномен здоровье можно определять через уровень культуры отношения к себе и окружающему миру во всех его проявлениях. Следовательно, культурологический подход к здоровью можно рассматривать также и одним из способов экологизации сознания учащихся. Воспитание культуры природолюбия - это, по сути, формирование качественно новой личности, способной жить в условиях глобализации в гармонии с техносферой и природной средой. Данный подход позволяет для сбережения здоровья использовать педагогические средства, формируя у 
учащихся представление о здоровье как личностно значимой экологовалеологической ценности, поскольку вне контактов с природной средой человек пока не научился (да и вряд ли сможет) жить полноценно. Следовательно, формирование культуры природолюбия (а значит и здоровьесбережения!) должно стать основополагающим в работе дошкольных учреждений и школ, поскольку этот процесс способствует развитию в современном обществе гармоничной личности и, следовательно, формированию нового отношения к природе, а также отношению к себе как части природы. Только духовно здоровая гармоничная личность способна бережно относиться к природе, выделяя себя из неё.

В связи с этим можно высказать предположение о том, что природнооздоровительные силы, являясь в теории и методике физического воспитания вспомогательным средством, могут, тем не менее, внести существенный вклад в экологизацию сознания учащихся. Для этого надо не так уж и много - чаще прибегать к физкультурно-оздоровительным занятиям на природном ландшафте, возможно даже в ущерб некоторым формальным программным требованиям по дисциплине «Физическая культура» (тем более, что многие из таковых по тем или иным причинам в реальной педагогической практике всё равно зачастую не выполняются, или существенно редуцированы). Это особенно актуально в условиях нынешней пандемии COVID-19 (и прочими подобного рода вызовами человечеству в будущем), затягивающейся, повидимому, надолго. Дистанционное же физкультурное образование, в нашем видении, явление весьма сомнительное и непродуктивное, рассчитанное в основном на людей уже имеющих опыт, осознание и внутреннюю мотивацию к самоорганизованной двигательной деятельности.

Относительно важности и возможностей экологизации физкультурнооздоровительных занятий, можно сказать следующее.

Во-первых, необходимо как можно больше таких занятий проводить на открытом воздухе, когда природный ландшафт, открытое пространство, инсоляция, температурно-влажностный режим, естественное движение воздуха, его ионизация и другие факторы сами по себе способствуют оздоровлению. Многими исследованиями доказано, что оздоровительный эффект активного отдыха на природе в двигательном режиме на 30\% выше, чем от пассивного отдыха. Ещё более высокие результаты даёт тренирующий режим отдыха.

Во-вторых, спектр физических упражнений, спортивных и подвижных игр на природе не сокращается, а возможно даже и расширяется за счёт 
проявления большей самостоятельности и фантазии самих воспитанников и обучающихся. Физкультурно-оздоровительные занятия, проводимые вне помещения, всегда ассоциируются с большей свободой, эмоциональным подъёмом, формируя постепенно у учащихся упрощённую интрапсихическую связку: «физическая культура - это свободное проявление двигательной активности на лоне живой природы - на поляне, в лесу, парке, у реки и др.». Такое ассоциативное упрощение вполне допустимо, в том случае, если речь идёт о дошкольниках и младших школьниках.

Во-третьих, больше ориентироваться на этнокультурные традиции региона. Подвижные игры и упражнения должны развивать у детей не только двигательные способности, но и осознание принадлежности к окружающей природной среде, своему народу, этносу, своей малой родине, формировать внутреннюю эколого-валеологическую культуру здоровья. Такое возможно при использовании на занятиях в качестве подручных вспомогательных средств различные природные элементы: деревья, пни, брёвна, ветки, камни, песок, глину, воду, естественные преграды и многое другое. Здесь следует учитывать, что игры-упражнения с природным материалом эффективно помогают снять у детей напряжённость, невротические состояния, психологические комплексы (неуверенность, застенчивость, тревожность, различные фобии). Это своего рода «природотерапия».

Наконец, при выполнении общеразвивающих и гимнастических упражнений значительно активизируется процесс восприятия самого упражнения, если ребёнку поясняют, как и по какой причине это же самое делает животное, растение. Например: кошка, собака потягиваются, выгибают спину; змея сворачивается, извивается или наоборот выпрямляется, поднимая голову; заяц, кузнечик прыгают в длину, выпрыгивают в высоту; цапля, богомол застывают неподвижно; белка перемещается по веткам, обезьяна - по лианам, раскачивается на руках; выдра, бобр при нырянии задерживают дыхание; круглая колючка катится по ветру (вариант кувырка); лиана растёт и забирается вверх по дереву, палке, канату; муравьи тянут, волокут тяжёлую ношу; жуки, падая на спину, переворачиваются со спины на брюшко и многое другое. Необходимо доводить до понимания детей, что всё многообразие движений реально существует в природе, а сами движения необходимь и прекрасны по своей сути. Неспроста многие упражнения, например в йоге, обозначены названиями животных, растений. При этом необходим вербальный контакт с детьми с объяснением целесообразности этих движений не только 
для животных, но и для человека, как высшей формы развития живого на Земле. Более того, можно продемонстрировать на примере многих упражнений превосходство человека в его двигательных возможностях перед многими животными (например, в мелкой моторике, мимике, жестах, дыхательной и речеобразующей функции и пр.). Так осуществляются необходимые детям элементы экологизации сознания, формируются их двигательное творчество и валеоустановки самодостаточного типа.

Ещё одним аспектом взаимосвязи физической культуры и экологической культуры является такое мероприятие, как поход выходного дня. Данный вид внеурочной физкультурно-оздоровительной деятельности прописан во всех учебниках и пособиях по теории и методике преподавания физической культуры. Однако, в современных условиях подобный вид рекреационнооздоровительной деятельности не часто используется.

Туристические походы оказывают ни с чем несравнимый оздоровительный эффект, получаемый в результате воздействия на организм природных факторов: солнца, воздуха, воды и многообразной двигательной деятельности. Доказано, что продолжительное выполнение умеренной нагрузки в виде циклических упражнений (ходьбы, бега, передвижений на велосипеде, на лыжах и т.п.) способствует совершенствованию жизненно важного качества - общая выносливость, качества, развитие которого существенно отстаёт у современных школьников. Кроме того, туристические походы способствуют личностному развитию, самопознанию, экологизации сознания, укреплению семьи, снимают психологические «зажимы», формируют важнейшие нравственные качества, развивают любознательность, приобщают к миру природы, воспитывая бережное отношение к ней.

Походы расширяют кругозор (особенно молодых людей), формируют представления об истории родного края, традициях и культуре народа. Именно в совместных походах возникает тот духовный контакт между поколениями, о котором многие родители только мечтают. У участников формируются навыки выживания в природной среде (умение разжечь и потушить костер, оборудовать стоянку, лагерь, приготовить пищу и пр.), воспитывается самостоятельность и коллективизм, ответственность и организованность, развивается воля и чувство юмора. Двигательная деятельность, осуществляемая на лоне природы, является благодатной почвой для формирования культуры общения, а человек не может существовать вне культуры. Более того, «индивид, не освоивший в той или иной степени культурные модели поведения, - 
феномен исключительный ... У него просто нет психологических проблем; в цивилизованном обществе он сам становится проблемой для окружающих» $[9$, c.203].

В зависимости от степени двигательной подготовленности группы туристические походы могут быть различной степени сложности и включать в себя следующие составляющие: ходьба по грунтовой дороге, по лесу, подъёмы и спуски с гор, преодоление разнообразными способами естественных препятствий различной сложности, тренировка глазомера, различных видов равновесия, движения (перешагивания, перелезания, переползания, прыжки в длину, в глубину, перепрыгивания и пр.). Таким естественным образом у человека формируется осмысленное отношение к собственному телу, его состоянию, возможностям. Но это и есть формирование валеоустановок, приобщение к физической культуре, здоровому образу жизни, т.к. двигательная активность является мощным стимулом развития жизненных функций, особенно у растущего организма.

Существенной стороной влияния походов на личность является также и повышенный эмоциональный тонус. Во время туристических походов у участников улучшается настроение, появляется чувство радости, удовольствия, повышается психологическая устойчивость, снимается психическое напряжение, связанное со сложностями социальной жизни. Это достигается неформальным общением, подвижными играми, наблюдениями за различными природными явлениями, животным и растительным миром, при непосредственной включённости в эти сферы.

Таким образом, высокая оздоровительная эффективность туризма даже в самом примитивном его применении объясняется тем, что в нём теснейшим образом связываются все три средства физического воспитания: и движения в любых формах, адекватные физиологическим возможностям, и оздоровительные силы природы, и гигиенические факторы. В результате у человека формируется более гармоничная картина мира, либо она предстаёт перед ним с наиболее выгодной стороны, что способствует гармонизации духовной, физической и социально-психологической составляющих здоровья и здорового образа жизни. Характерно, что такие внутриличностные трансформации при общении с природой происходят практически у всех участников данных мероприятий, независимо от половозрастных, образовательных, профессиональных и других особенностей. 
В связи с вышеизложенным нами было проведено социальнопедагогическое исследование с целью выяснения реального времени пребывания на открытом воздухе учащихся во время уроков по физической культуре, а также связи интереса учащихся к таким занятиям, в зависимости от их учебного опыта по физической культуре. В исследовании принимали участие учителя физической культуры (18 человек) шести средних общеобразовательных школ г. Екатеринбурга и г. Шадринска, а также старшие школьники (117 человек) этих школ.

Учителям задавался вопрос о том, сколько времени в течение учебного года младшие школьники проводят на открытом воздухе (по возможности в лесопарковой зоне) во время физкультурных занятий. Результаты следующие: большинство педагогов (10 человек) около четверти времени отвели на такие занятия, шесть человек - 10\% времени и два педагога - по 5\%. Занятия на открытом воздухе в основном (для 80\% учащихся) проходили в школьном дворе, на спортивной площадке, и лишь 20\% случаев это касалось лесопарковой зоны (в подобных местах, как правило, проходит лыжная подготовка в зимний период).

Исследование ответов учащихся старших (10-11-й) классов касалось обнаружения корреляционной связи между желанием проводить уроки физической культуры на открытом воздухе и наличием практики проведения таких уроков в школе. Получены следующие результаты. Большинство (73\%) учащихся обоих полов не имеют желания к такому виду занятий, 19\% юношей и 22\% девушек относятся индифферентно, и лишь 8\% юношей и 5\% девушек имеют выраженное желание оставаться на открытом воздухе во время учебных занятий. Задавался также и вопрос учащимся: «Как часто вам приходится бывать во время уроков физической культуры на открытом воздухе, в лесопарке?». Сопоставляя эти данные, были определены коэффициенты корреляции между временем, проведённым во время уроков на открытом воздухе, и желанием заниматься физической культурой в таком варианте. У всех учащихся коэффициент корреляции оказался значим (при $\mathrm{P}<0,05, \mathrm{R}_{\text {крит. }}=$ 0,27), у юношей данная связь составляет $\mathrm{R}=0,64$, у девушек $\mathrm{R}=0,56$.

При такой ситуации со слабым использованием природнооздоровительного фактора на учебных занятиях, в принципе, становится понятным, что некоторые тестовые упражнения по системе ФВСК «ГТО» современным детям и подросткам выполнить просто не под силу. Например, по нашим наблюдениям, метание спортивного снаряда на дальность вызывает у подавляющего числа школьников существенные затруднения, даже у, казалось 
бы, хорошо подготовленных. Причины понятны, в свободное время дети не играют зимой в снежки (дворовая культура сейчас практически отсутствует), а на учебных занятиях такое возможно только в открытой зоне, куда они попадают редко.

Интерпретируя полученные данные в пределах темы исследования можно обозначить следующие выводы.

1. Младшие школьники на уроках физической культуры в основном лишены активной двигательной физкультурно-оздоровительной деятельности на природном ландшафте. Следовательно, у них и не образуется привычек к таким занятиям, и не формируется понятийная связь категорий: физическая культура - природа - здоровье.

2. У старших школьников обнаружена тесная корреляционная зависимость времени проведения уроков по физической культуре на открытом воздухе и желанием к таким урокам. Те из учащихся, кто чаще оздоравливался на физкультурных занятиях на открытом воздухе имеют и более активные установки на использование природно-оздоровительных средств в физическом воспитании. То есть, деятельностный и средо-ориентированный подходы полностью оправданы, когда речь идёт о процессах формирования здоровья и экологизации сознания школьников.

В рамках другого экспериментального исследования нами были рассмотрены условия проведения уроков по физической культуре в двух группах младших школьников с двух позиций: 1) анализа структурных компонентов их валеоустановок и 2) показателей физического здоровья. В обеих группах время, отведённое на уроки физической культуры, составляло три часа в неделю. Первая группа школьников (два класса) на уроках по физической культуре занималась преимущественно на открытом воздухе (на спортивных площадках в лесопарке). Вторая группа - контрольная (также два класса) находилась в лучших (с утилитарно-прагматической позиции) условиях - занималась преимущественно в закрытых оборудованных спортивных помещениях. Таким образом, вторая группа имела лучшие технические условия для решения основных дидактических задач, безопасного проведения занятий, развития двигательного потенциала учащихся, а значит, для оздоровления. Однако в педагогике зачастую не бывает однозначного (тем более, однозначно правильного!) решения, это область задач открытого типа, следовательно - задач творческих. Во всяком случае, мы ориентировались на мнение, встречающееся в научных и методических публикациях, авторских программах по физическому 
воспитанию, о том, что физкультурные занятия у школьников следует чаще проводить в открытых зонах отдыха, лесопарках, что способствует и физическому оздоровлению, и экологизации сознания. Тем не менее, видим, что в реальной педагогической практике стремление преподавателей к использованию природно-оздоровительных комплексов для физкультурных занятий не столь частое явление.

У школьников отслеживались следующие показатели: 1) структурные компоненты валеоустановок изучались на основе анкетирования по специально созданным для этой цели анкетам; 2) одновременно методом экспресс-оценки уровня физического здоровья измерялись и оценивались антропометрические данные, АД, проба Штанге, индексы - Кетле-2, Робинсона, Скибинского, Шаповаловой, Руфье [8].

По результатам проделанной работы можно сформулировать краткие выводы.

1. В первой группе школьников (использовавших ландшафтно-средовый вариант физкультурных занятий) вне зависимости от половой принадлежности и уровня физического здоровья валеоустановки оказались ближе к самодостаточному типу, нежели у школьников противоположной группы. Когнитивная составляющая валеоустановок в обеих группах практически совпадает, однако различия наблюдаются в эмоционально-оценочной компоненте и, особенно, в поведенческой, деятельностной.

2. У девочек несколько ярче, в отличие от мальчиков, выражена эмоционально-оценочная компонента. Их описания эмоциональных переживаний состояния здоровья и болезни более контрастны. По когнитивному и поведенческому компонентам валеоустановок достоверных различий между полами не обнаружено. Поскольку эмоции в данном возрасте составляют основу мотивации поведения и деятельности, то можно надеяться на их существенный вклад в субъективное мотивационное поле, формирующее личность безопасного типа в будущем, именно у девочек. Это важно, поскольку воспитательные воздействия открытого, эмотивного типа более характерны для женского пола.

3. По окончании почти девяти месяцев учебных занятий выявлены более высокие показатели физической компоненты здоровья у школьников первой группы (в основном уровни «средний» и «выше среднего»), в отличие от обобщённых показателей во второй группе (в основном «средний» уровень).

4. Восприятие школьниками первой группы категорий «физическая 
культура» и «природно-оздоровительные средства» ассоциативно намного ближе, нежели во второй - «природно-депривированной» группе занимающихся.

В завершение рассматриваемой темы об экологизации сознания детей и учащейся молодёжи средствами образования можно констатировать, что экологизация валеоустановок посредством адаптирующе-развивающей физкультурно-оздоровительной деятельности способствует не только более эффективному физическому оздоровлению школьников, но и возникновению у них ассоциативно-мотивационного комплекса, связывающего физкультурную деятельность с окружающей природной средой. Данное обстоятельство позволяет также говорить о том, что экологизация валеоустановок является одним из основных компонентов развития личности «безопасного типа». Под таким типом личности понимается человек, «безопасный для себя, окружающих, среды обитания, готовый к предупреждению и преодолению опасных ситуаций, а в случае необходимости, и к защите себя, социума и природы от внешних угроз» [6, c.50]. Среди основных черт такой личности выделяют, в том числе, и бережное отношение к окружающему миру.

Таким образом, процесс здоровьесбережения необходимо рассматривать гораздо глубже, а в педагогических технологиях должны быть задействованы экологические здоровьесберегающие факторы природной среды, приближающие обучающегося к таковой.

В заключение следует сказать, что здоровьесбережение учащихся необходимо рассматривать гораздо шире нормативно-медицинской модели здоровья, а педагогические усилия должны быть ориентированы на формирование личности обучающихся с помощью «физкультурноэкологических» комплексов. Ссылаясь на мнение 3.И. Тюмасевой [13], следует сказать, что решение комплексных задач по оздоровлению подрастающего поколения надо начинать с повышения качества образования выпускников педагогических вузов. Это возможно на основе интеграции идей экологии, здоровья и психофизической культуры, разноуровнего экологовалеологического образования в области здоровья и оздоровления не только естественных, но и искусственных систем, построенных по экологовалеологической аттракции. При этом естественным образом должна обеспечиваться интеграция отдельных учебных курсов экологического, медикобиологического и физкультурно-оздоровительного циклов общепрофессиональной подготовки студентов педагогических (возможно, и 
медицинских) вузов в непрерывную содержательную линию «здоровье человека и здоровье окружающей среды». В дальнейшем можно надеяться на адекватную трансляцию интериоризованных выпускниками вузов эколого-валеологических ценностей детям как в ДОУ, школах, так и в своих семьях, трудовых коллективах.

\section{Список литературы}

1. Васильева, О.С. Психология здоровья человека: эталоны, представления, установки: учебное пособие / О.С. Васильева, Ф.Р. Филатов. М.: Академия, 2001. - 352 с.

2. Дерябо, С.Д. Экологическая педагогика и психология : учебное пособие. / С.Д. Дерябо, В.А. Ясвин. - Ростов-на-дону: Феникс, 1996. - 480 с.

3. Зотова, Т.В. Актуальность формирования культуры природолюбия // Оздоровление средствами образования и экологии: мат-лы III межд. науч.практ. конф. / Т. В. Зотова. - Челябинск: Челябинский гос. пед. ун-т., 2006. - С. 18-19.

4. Кривских, О.Г. Формирование экологической картины мира у младших школьников средствами сезонных экскурсий в природу в процессе обучения естествознанию: дисс...канд. пед. наук. - Екатеринбург, 2007. - 227 с.

5. Моисеева, Л.В. Теория и методика естественнонаучного и эковалеологического образования детей младшего школьного возраста: учебнометод. пособие / Л.В. Моисеева, О.Н. Лазарева, И.Р. Колтунова. - Екатеринбург : Урал, гос. пед. ун-т, 2000. - 108 с.

6. Неверов, В.Н. Формирование личности безопасного типа поведения при обучении ОБЖ: психолого-педагогический аспект / В.Н. Неверов, A.M. Деркач. // Молодой ученый. - 2014. - № 5.1 (64.1). - C. 50-53. - URL: https://moluch.ru/archive/64/10313/ (дата обращения: 11.11.2020).

7. Повещенко, Н.П. Охрана здоровья подрастающего поколения как педагогическая проблема: история, современность : автореф. дис. ... канд. пед. наук : 13.00.01. - Владимир, 1996. - 22 с.

8. Поляков, С.Д. Мониторинг и коррекция физического здоровья школьников : метод. пособие / С. Д. Поляков, С. В. Хрущёв, И.Т. Кореева, М.Н. Кузнецова, А. М. Соболев. - М. : Айрис пресс, 2006. - 91 с.

9. Психология здоровья : учебник для вузов / под ред. Г. С. Никифорова. СПб.: Питер, 2003. - 607 с. 
10. Реан, А. А. Психология личности. Социализация, поведение, общение / А. А. Реан. - СПб.: «прайм-ЕВРОЗНАК», 2004. - 416 с.

11. Сикорская, Г. П. Учёт экологических факторов в формировании здоровьесберегающей среды жизнедеятельности образовательного учреждения // Здоровье, физическое развитие и образование: состояние, проблемы и перспективы: мат-лы регион. науч.-практ. конф. / Г.П. Сикорская. Екатеринбург: РГППУ, 2005. - С.223-224.

12. Тюмасева, 3. И. Валеология и образование / 3. И. Тюмасева, Б. Ф. Кваша. - СПб. : МАНЭБ. - 2002. - 380 с.

13. Тюмасева, 3. И. Формирование готовности студентов педагогических вузов к оздоровительной работе в общеобразовательных учреждениях // Оздоровление средствами образования и экологии: мат-лы III межд.. науч.практ. конф. / 3. И. Тюмасева. - Челябинск: Челябинский гос. пед. ун-т., 2006. C.3-9.

(С) О. Ю. Малозёмов, Л. В. Лагунова, 2020 
УДК 781

\title{
ТВОРЧЕСКИЕ ФОРМЫ РАБОТЫ НАД БИОГРАФИЯМИ КОМПОЗИТОРОВ В КУРСЕ МУЗЫКАЛЬНОЙ ЛИТЕРАТУРЫ КАК СРЕДСТВО ПОВЫШЕНИЯ УЧЕБНОЙ МОТИВАЦИИ СТУДЕНТОВ. ИЗ ОПЫТА РАБОТЫ В ПЕРИОД ДИСТАНЦИОННОГО ОБУЧЕНИЯ
}

\author{
Огнева Оксана Григорьевна \\ преподаватель \\ КГБПОУ «Красноярский колледж искусств \\ имени П.И. Иванова-Радкевича»
}

Аннотация: статья предназначена преподавателям музыкальнотеоретических дисциплин колледжей искусств, в ней представлены различные творческие формы изучения творчества композиторов: страница ВКонтакте, дневник, интервью и другие.

Ключевые слова: музыкальная литература, Людвиг ван Бетховен, Франц Шуберт, Карл Мария фон Вебер, Феликс Мендельсон-Бартольди.

\section{CREATIVE FORMS OF WORK ON BIOGRAPHIES OF COMPOSERS IN THE COURSE OF MUSICAL LITERATURE AS A MEANS OF INCREASING THE EDUCATIONAL MOTIVATION OF STUDENTS. FROM WORK EXPERIENCE DURING THE PERIOD OF DISTANCE LEARNING}

\section{Ogneva Oksana Grigorievna}

\begin{abstract}
: the article is intended for teachers of music-theoretical disciplines of art colleges, it presents various creative forms of studying the work of composers: VKontakte page, diary, interviews and others.

Key words: musical literature, Ludwig van Beethoven, Franz Schubert, Carl Maria von Weber, Felix Mendelssohn Bartholdy.

Предлагаемая вниманию читателя работа являеется продолжением статьи «Неправильная музыкальная литература» не только детям. Из опыта проведения занятий со студентами в период дистанционного обучения» $[1$, c. 58-70], в которой были представлены несколько вариантов работы над
\end{abstract}


изучением биографий композиторов в курсе музыкальной литературы колледжа искусств. Творческий посыл преподавателя был облачен в следующие форматы заданий: «Если бы Бетховен вел личную страницу ВКонтакте», «По страницам дневника Франца Шуберта», «Великие интервью журнала Rolling Stone. Карл Мария фон Вебер».

Поскольку основной платформой для координации работы со студентами, находящимися «по ту сторону монитора» в КГБПОУ «Красноярский колледж искусств имени П.И. Иванова-Радкевича» была выбрана социальная сеть ВКонтакте, многие заданий были ориентированы на формат интернет-страниц.

В дополнение к работе «По страницам дневника Франца Шуберта», ребятам было предложено вступить в его «Клуб почитателей» ВКонтакте. Преподавателем был разработан текстовый макет фан-клуба в социальной сети.

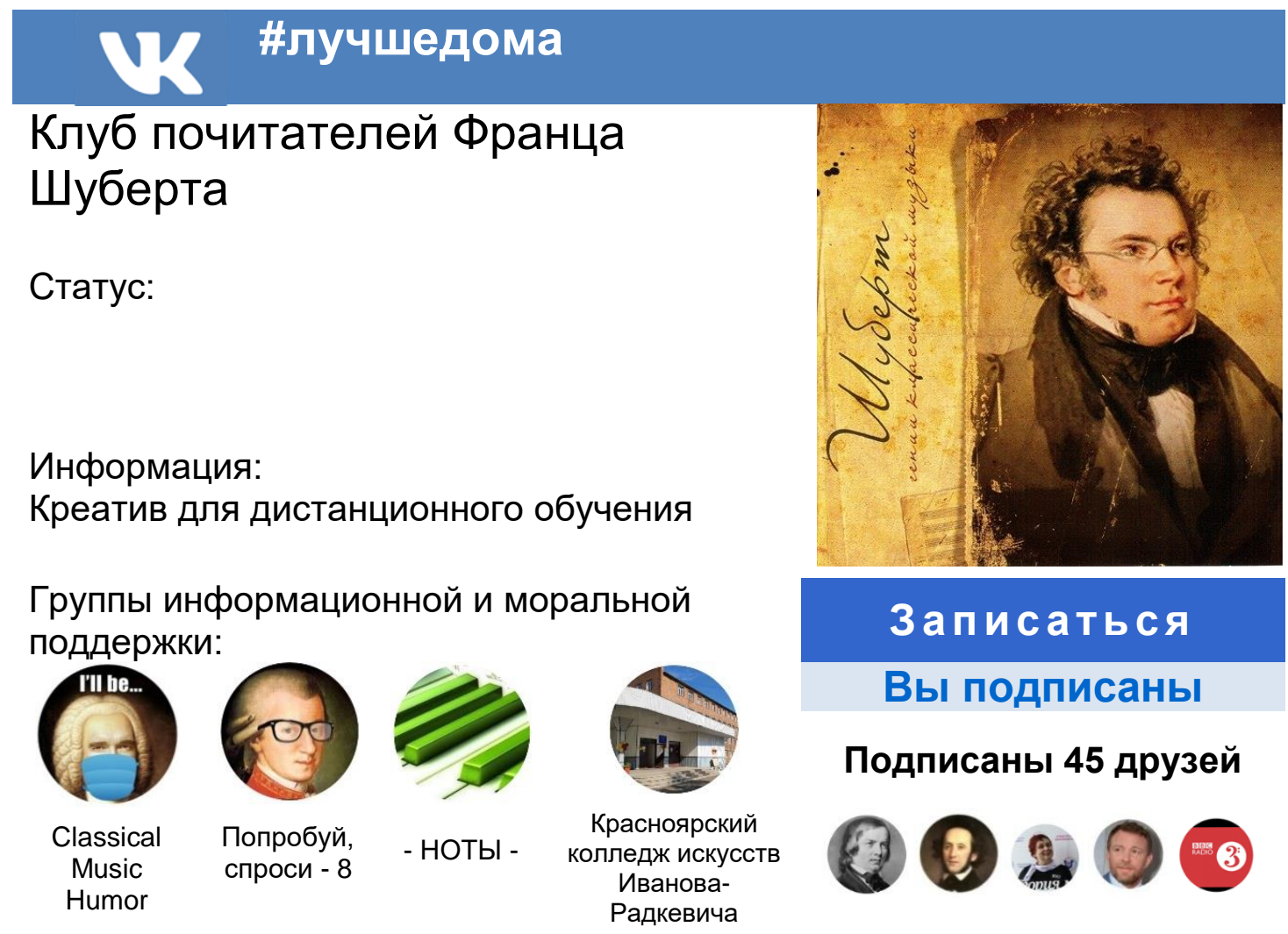

По аналогии с выполнением квеста с личной страницей Людвига ван Бетховена сначале студентам было необходимо придумать текст вводного информативного раздела «сообщества». Приведем в пример ряд фрагментов работ студентов: 


\section{\#лучшедома}

\section{Клуб почитателей Франца Шуберта}

«Песенка складная! Кто её написал?»

- Франц Шуберт о своей песне

Информация:

Креатив для дистанционного обучения

- Всё о композиторе и даже больше.

- Файл «По страницам дневника Шуберта» в обсуждениях сообщества

- Викторина по творчеству Франца Шуберта 13-18 марта Ссылка на облако - https://cloud.mail.ru/public/fcLQ/5uiu7MtK2 (только для участников сообщества)

- Подача заявок на участие в «ШубертиадаSpringOnline» будет осуществляться с 20 апреля по 1 мая 2020 года.

- Ноты и печатные материалы по композитору находятся в документах сообщества

- За нецензурную лексику и оскорбление чувств романтиков - БАН

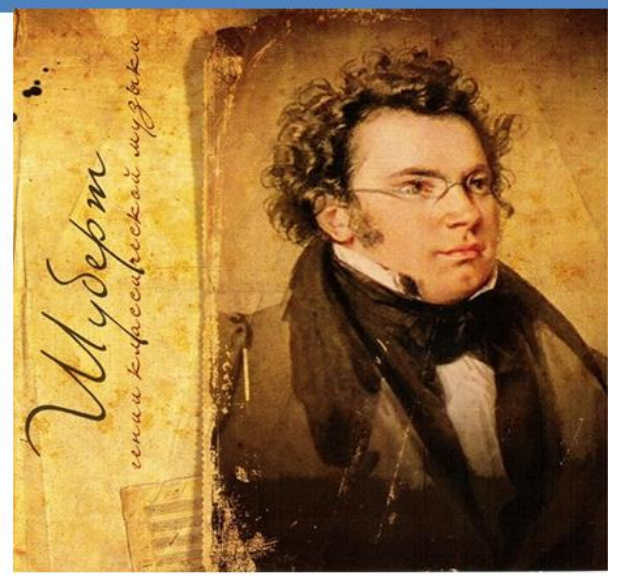

Фрагмент работы Рожковой Юлии, отделение «Оркестровые духовые и ударные инструменты»

\section{\#лучшедома}

\section{Клуб почитателей Франца Шуберта}

Вся жизнь - Лесной Царь, а ты в ней - младенец, или коротко о депрессии во время карантина...

Информация:

Всех, кто любит Франца Шуберта-приглашаем в нашу группу! Вас ждет много интересных обсуждений, интерактивов, и, конечно же, прекрасной музыки!

Мы в других соцсетях:

Ig: instagram.com/club.pochitatelei.franca.shuberta $\mathrm{Fb}$ : facebook.com/club.pochitatelei.franca.shuberta Ok: ok.ru/club.pochitatelei.franca.shuberta

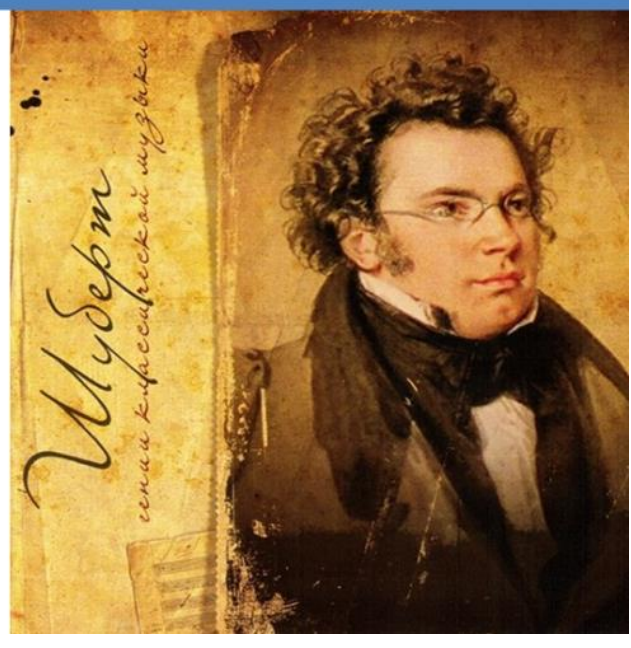

\section{Фрагмент работы Черноусовой Анны, отделение «Сольное и хоровое народное пение»}


\#лучшедома

Клуб почитателей Франца Шуберта

«То, что рождено в страданиях, доставляет окружающему миру наибольший восторг»

- Франц Шуберт

Информация:

Моя музыка - это результат моего таланта и моей нищеты.

Нет в мире вещи, подобной музыке счастья.

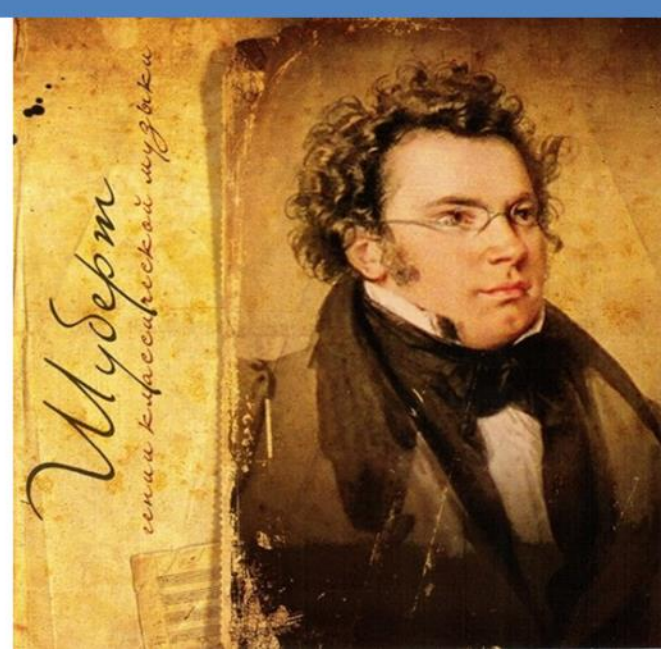

Фрагмент работы Кухарева Владимира, отделение «Сольное и хоровое народное пение»

Далее студенты должны были узнать по портретам и логотипам «участников клуба» (ими оказались композитры Роберт Шуман, Феликс Мендельсон-Бартольди, кинорежиссер Гай Ричи и британская радиостанция BBC Radio 3), определить события, связывющие членов фан-сообщества с творчеством Франца Шуберта и написать от их имени комментарии.

Также приведем в пример ряд фрагментов работ студентов:

\section{Роберт Шуман}

1838

Здравствуй, дорогой Франц. Я нашел твою «Большую симфонию» До мажор, она была исполнена в Вене. Публика была в полном восторге от услышанного. Жаль, что ты не сможешь её послушать... Но это ничего страшного. Надеюсь, что на том свете мне всё-таки удастся сыграть её тебе. Не знаю, зачем я пишу все это, прекрасно понимая, что это не твоя страница, но пусть мои записи останутся потомкам, которые будут помнить о тебе и обо мне долгие годы своей жизни...

Фрагмент работы Ничипорчика Ивана, отделение «Музыкальное искусство эстрады» 


\section{Роберт Шуман}

\section{8}

Друзья! Я обнаружил ценнейшую вещь в Вене - ноты «Большой симфонии» Шуберта.

\section{Феликс Мендельсон-Бартольди 1839}

Роберт, я хочу, чтобы это услышали люди. Жду тебя в Лейпциге! Решено, организуем концерт - я буду дирижировать.

\section{Гай Ричи}

14 декабря 2011

Друзья! Рекомендую к просмотру мой новый фильм «Шерлок Холмс: Игра теней». Не просто так я пишу именно здесь об этом. Ведь в одной сцене фильма вы сможете услышать песню Франца Шуберта "Die Forelle" в исполнении главного злодея - Профессора Мориарти!

\section{Фрагмент работы Сугатова Юрия, отделение «Музыкальное звукооператорское мастерство»}

\section{$3 \quad$ BBC RADIO 3}

С Шубертом нас связывает сериал, который мы посвятили ему. Мы провели целую серию в Broadcasting House, снимая все - от студийных выступлений до «Лаборатории Шуберта» с ведущим Томом Сервисом. Мы были в напряжении всю неделю, снимая в импровизированном стиле прямого радио и работая круглосуточно, редактируя фильмы на месте для использования на веб-сайте Radio 3 и в социальных сетях.

Фрагмент работы Штермера Андрея, отделение «Музыкальное звукооператорское мастерство» 


\section{Роберт Шуман}

1838

Я бесконечно счастлив, друзья мои! Да, да! Я счастлив!

И поэтому спешу сообщить вам о своей радости!

Сегодня, я нашёл новую партитуру! И не просто партитуру, а партитуру Франца Шуберта!

Да чего уж там говорить! Я нашел целую симфонию! Симфонию До мажор! Она была среди бумаг брата композитора. И это невероятно, как порой затерянные листы бумаги приносят действительно что-то нужное!..

Даже лучше будет сказать, что они принесли мне весточку об одном талантливом человеке!..

И это по-настоящему замечательно, ведь мы обязательно должны помнить о таких творческих людях!

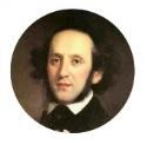

\section{Феликс Мендельсон-Бартольди}

1839

Да... Можно сказать, что этот день был не особо лёгким. Но, кроме усталости, ко мне пришли и совершенно другие, нужные чувства! Этот день зарядил меня особой энергией, без которой все творческие люди начинают чувствовать себя опустошёнными и никому не нужными!

Сегодня я дирижировал До мажорную симфонию Шуберта, найденную Робертом Шуманом.

И, бесспорно, это событие было для меня очень приятным!

Не правда ли, лучше устать за выполнением своего любимого дела, но, зато, чувствовать себе хорошо в душевном плане, чем отдохнуть где-нибудь в поместье физически, но не насытиться духовно?

А вы как считаете? 


\section{(3) BBC RADIO 3}

Здравствуйте! Здравствуйте! Здравствуйте!

Bac приветствует официальная страница BBC RADIO 3!

Спешим рассказать вам, нашим дорогим подписчикам, и нашим друзьям из сообщества Клуба почитателей Франца Шуберта, о проделанной нами работе!

Напоминаем о событии: с 23 по 31 марта мы посвятили 200 часов беспрерывного вещания австрийскому композитору Францу Шуберту.

Итак, вопрос: «Что же у нас получилось?»

На него мы можем с легкостью ответить, что наш марафон в честь 215 лет со дня рождения Шуберта, несомненно удался!

В течение 9 дней на нашем \#BBCRADIO3 звучали только произведения этого удивительно композитора, а также было проведено 24 прямые трансляции с концертов!

Ещё, мы хотим бесконечно поблагодарить нашего слушателя!

Спасибо, что оставались с нами, и так же, как и мы, восхищались этой чудесной музыкой!

\section{Фрагмент работы Черноусовой Анны, отделение «Сольное и хоровое народное пение»}

Дистанционное обучение и режим самоизоляции стали непростым испытанием и для преподавателей, и для учащихся. Отсутствие непосредственного контакта со сверстниками, коллегами дало определенный эмоциональный сбой, поэтому и форматы творческих заданий для дистанционной работы искренне хотелось наполнить тоном живого общения. Поэтому в завершении задания студенты обнаружили на страничке «клуба» и ряд сообщений от лица своего преподавателя.

\section{Оксана Огнева 1 апреля 2020}

Приветствую своих студентов! Мы с вами давно не виделись! Но технологии дистанционного обучения не дадут нам скучать! Сейчас, к сожалению, мы ограничены в передвижении, и нам только и остается вспоминать о наших прошлых путешествиях.... 
Что же, одним приятным и полезным воспоминанием я бы хотела сегодня поделиться с вами и дать ряд рекомендаций)))

Если когда-то у вас появится желание и возможность посетить Баварские Альпы, я бы вам посоветовала отправиться в городок Миттенвальд, посетить музей скрипок и прогуляться по ущелью Лойташкламм, расположенному на границе между Германией и Австрией. Лучше всего начать прогулку с австрийской стороны, тогда вы будете двигаться вниз с горы по течению ручья)

А теперь - самое главное! На входе в ущелье вас будут приветствовать ноты одного из произведений Франца Шуберта!!!
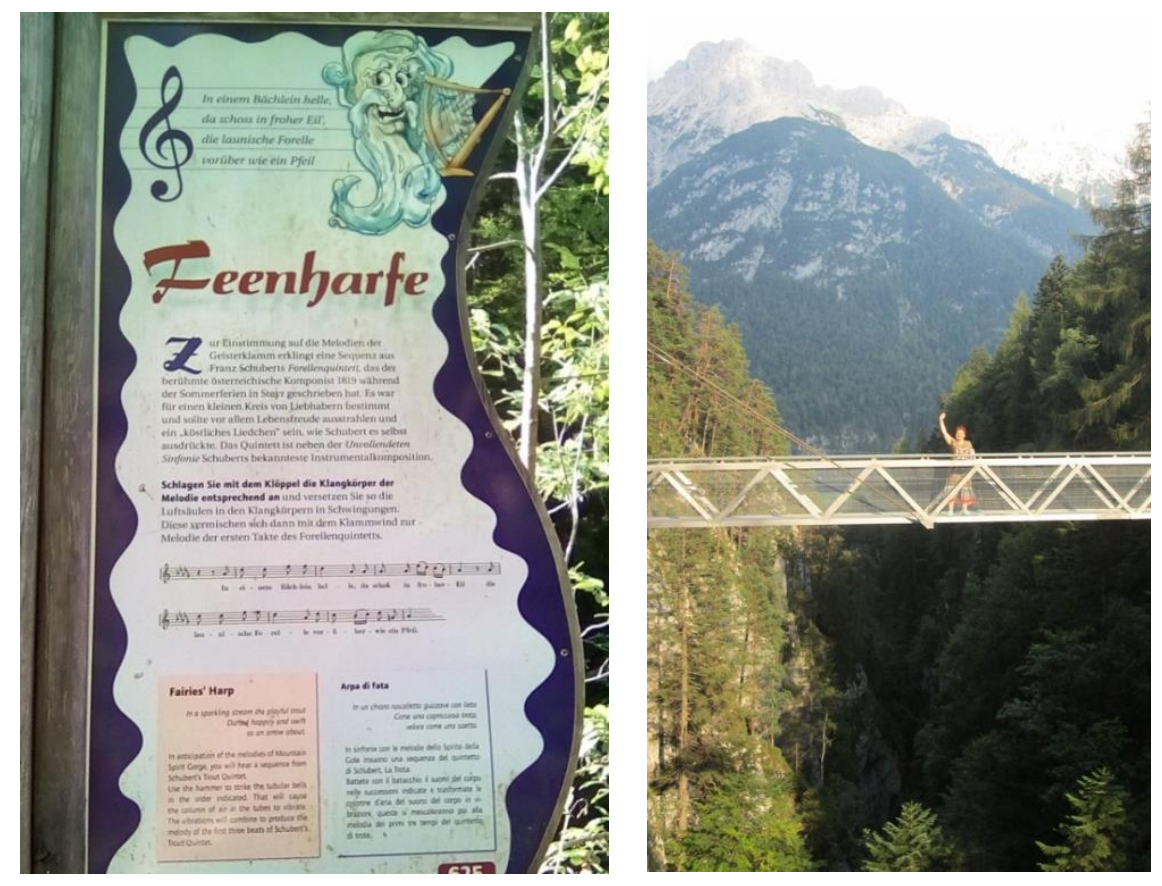

\section{Оксана Огнева ответила}

P.S.

Если вы не рассмотрели нотки на моей фотографии, то к вам на помощь придет наш самый лучший друг, товарищ и брат - клавир)))

Напишите мне в ответ на мой комментарий - какое это произведение?:; 

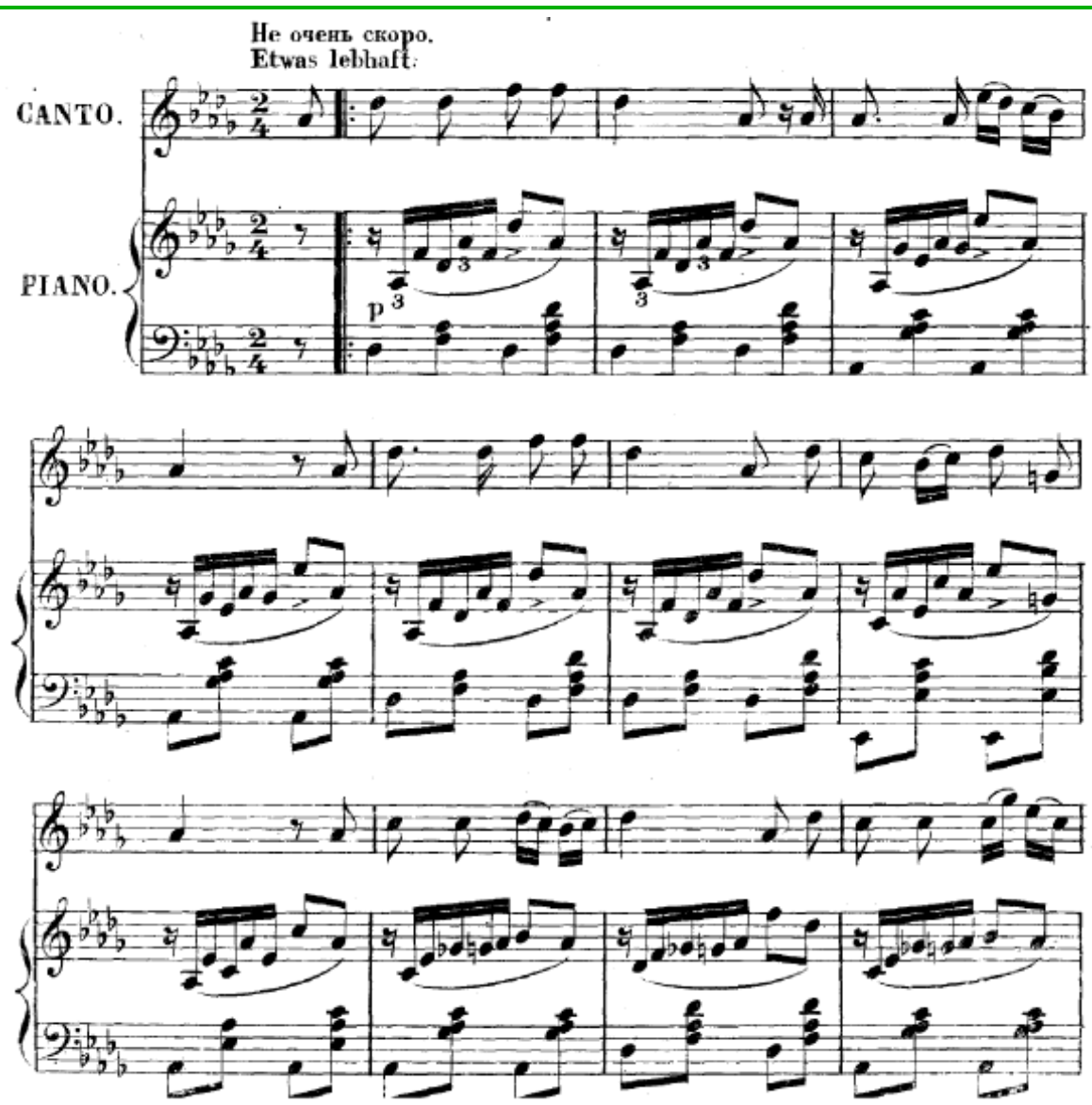

Свавильный Павел ответил

Оксана Григорьевна, это же Die Forelle! Написал эту песню Шуберт... примерно в 1817 году

Тут же, с длинной гибкой

Лесой рыбак сидел, И с злобною улыбкой На рыбок он смотрел.

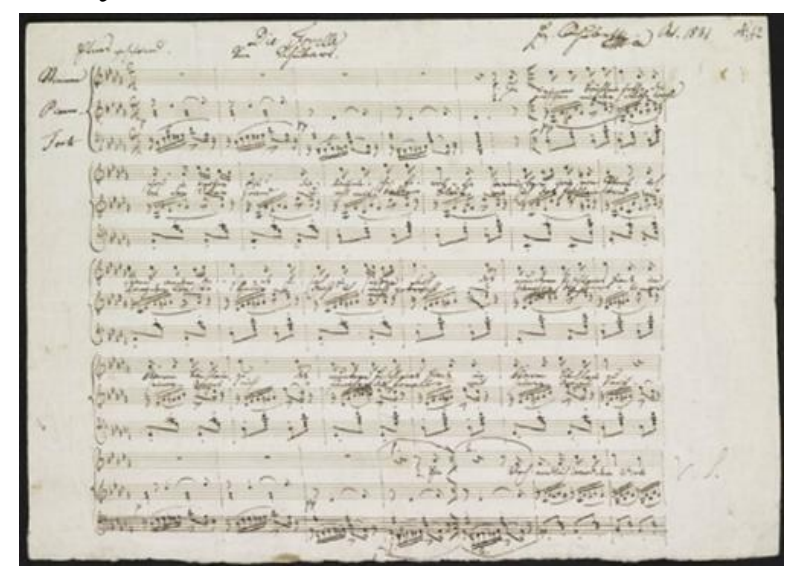

Рахманов Рамазан прислал фрото

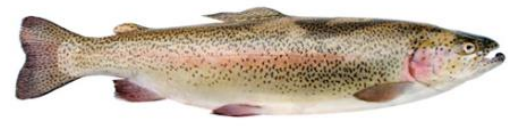




\section{Оксана Огнева ответила}

Кстати! В клуб почитателей нужно обязательно пригласить ещё одного композитора-романтика, виртуозного пианиста, который делал многочисленные переложения и фортепианные транскрипции произведений Франца Шуберта!

Прикрепите в ответ на мой пост его фотографии!

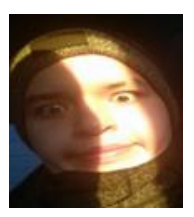

Рахманов Рамазан ответил и прислал фото

Ференц
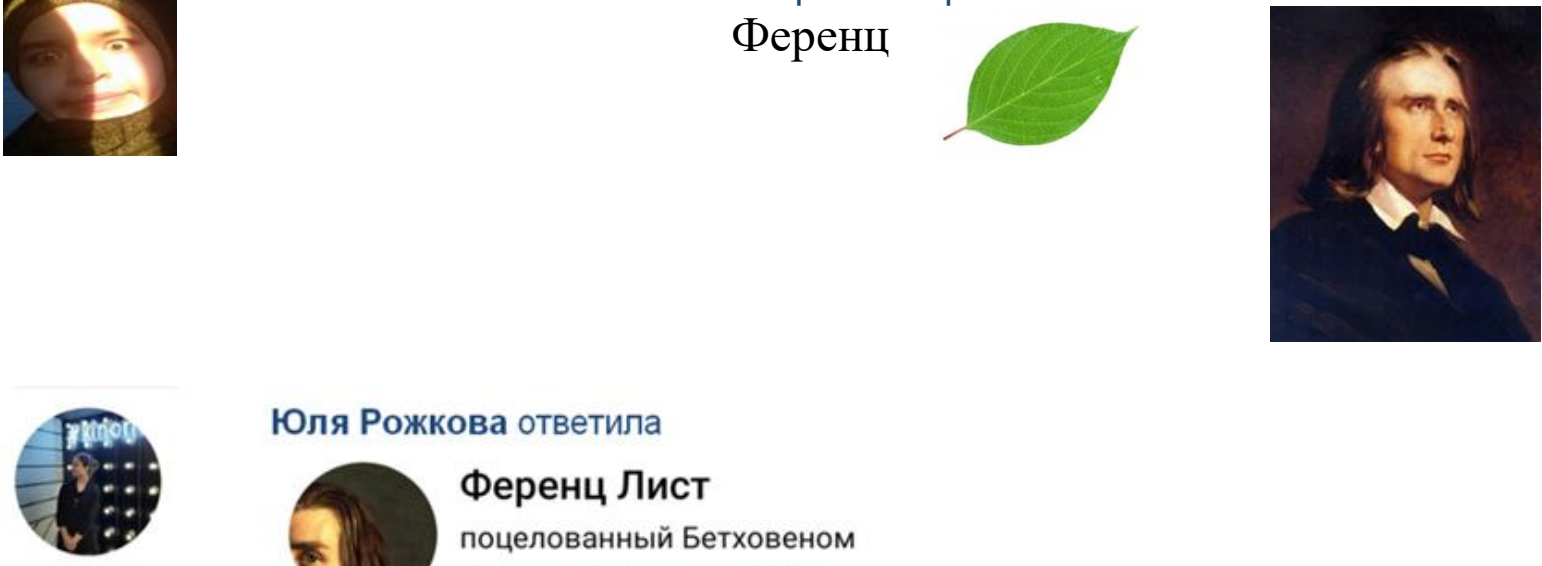

Юля Рожкова ответила

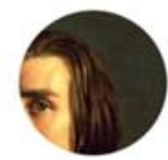

\section{Ференц Лист}

поцелованный Бетховеном

был в сети 2 апреля в 9:35

Ференц Лист - id589275568

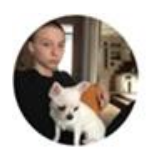

Канзычакова Элина ответила

Ференц Лист
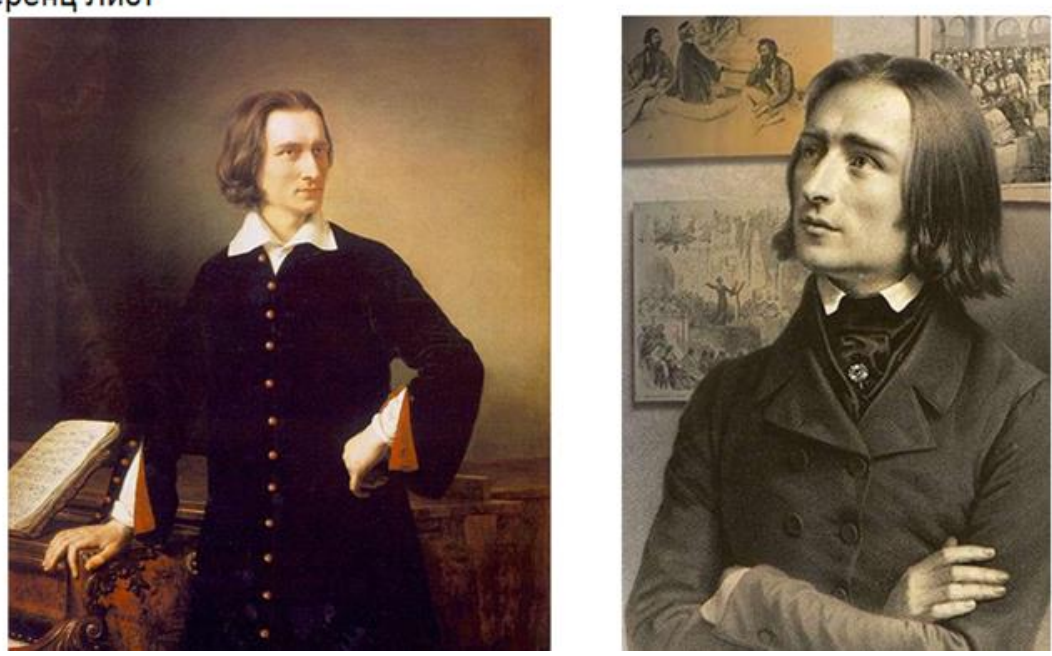

Елизавета Халитова ответила

Приглашу Ференца Листа

Ференц Лист

1845

У меня есть собственные переложения симфоний Бетховена и Берлиоза, песен Шуберта, органных произведений Баха. 
Кульминацией «дистанционной связи» представителей XIX века со студентами стало появление в сети своебразной online-консерватории под руководством Феликса Мендельсона-Бартольди. Кому как не основателю системы профессионального образования в сфере искусства стоило доверить проведение музыкальных викторин!

На страницах Феликса Мендельсона-Бартольди, которые были созданы для каждой группы отдельно, был размещен ряд заданий и ответов учащихся, которые и предлагаются далее вниманию читателя.

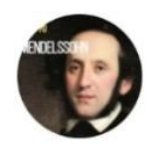

Jakob-Ludwig-Felix Mendelssohn-Bartholdy

14 апр в 14:41

Приветствую вас, юные музыканты!

«Дистанционный» привет из XIX века шлет вам основатель Лейпцигской консерватории Феликс Мендельсон-Бартольди!

Я постиг все тонкости в вопросах организации учебных занятий, и достаточно хорошо разбираюсь в проблемах музыкального образования. Сегодня именно я проведу с вами проверочную работу и дам вам ряд заданий для самостоятельного изучения моей биографии.

Я уверен, вы хорошо подготовились и готовы к победе! Transmittere ad victoriam!!! Что же, с викторины и начнем!

Определите на слух фрагменты произведений моих современников. Жду фотоснимки ваших тетрадей с ответами у себя в сообщениях через 20 минут! Удачи, юные друзья!

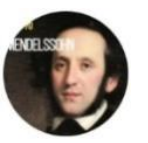

Jakob-Ludwig-Felix Mendelssohn-Bartholdy

14 апр в 14:41

Открыв для себя выход на новую историческую и виртуальную платформу, я обнаружил современных вам исполнителей, у которых фамилии созвучны моей!!! Смею вас заверить, что мы с Робертом Шуманом мастера в музыкальном поиске!

Что же, мне все это надо послушать, изучить, проанализировать. Не скрою - довольно странный для меня музыкальный язык ......

Будет переменка после выполнения викторины - зайдите в раздел «моя музыка».

А пока у меня к вам огромная просьба!

Юные музыканты! Познакомьте меня с музыкальными произведениями второй половины XIX века и ваших дней! Что бы вы мне посоветовали послушать? Прикрепите аудио в комментариях к этой публикации!

Премного благодарен! 


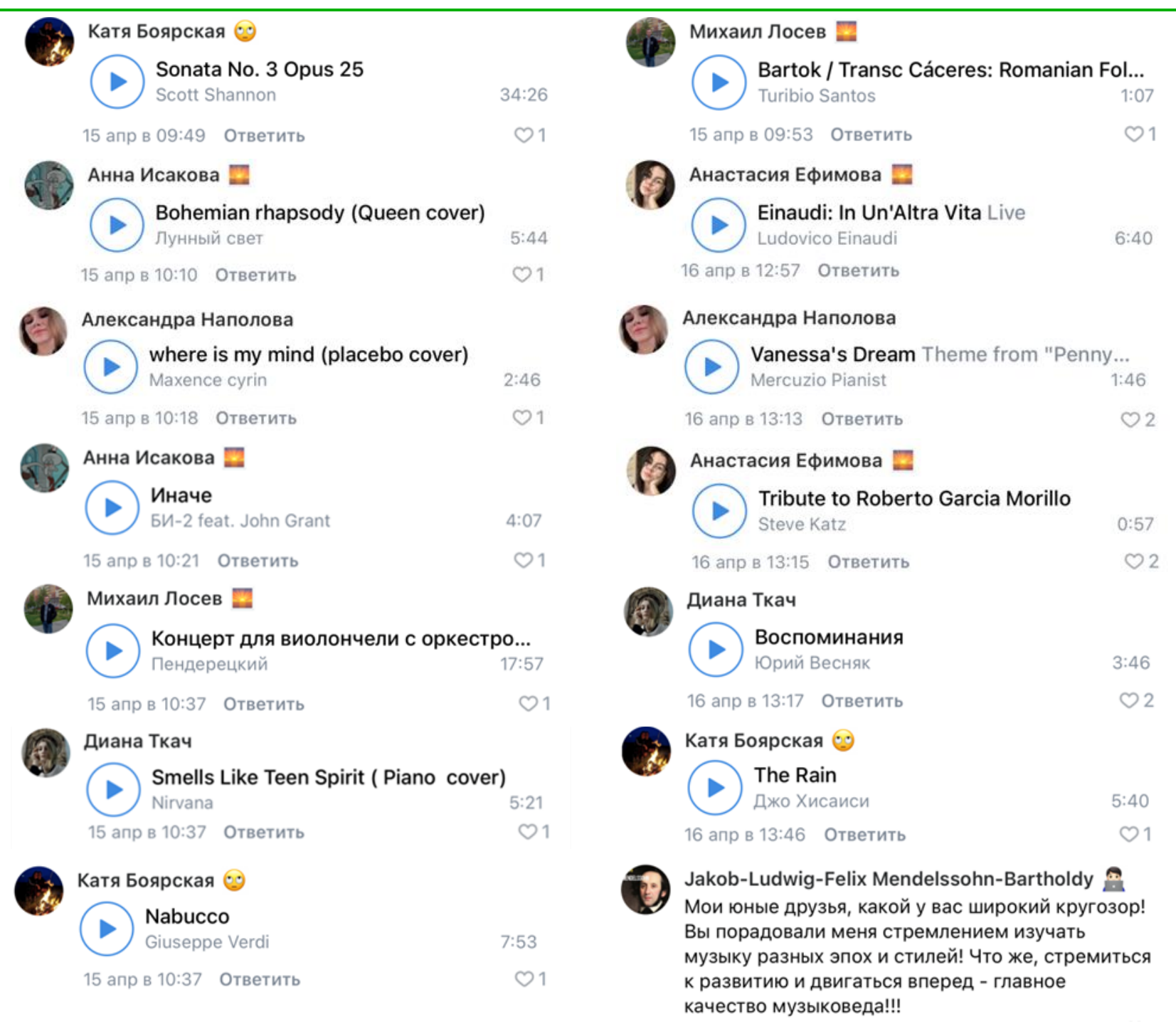

\section{Ответы студентов отделения «Теория музыки»}

Помимо проверочной викторины на странице Феликса МендельсонаБартольди были размещены и задания, включающие вопросы о современниках, учителях композитора, людях, повлиявших на формирование его личности. Часть вопросов предполагала ответы в личные сообщения маэстро, часть - в качестве комментариев к записи на стене. В последнем случае для студентов было поставлено главное условие - ответы не должны повторяться с ранее оставленными комментариями своих одногруппников.

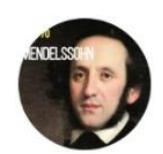

Jakob-Ludwig-Felix Mendelssohn-Bartholdy 15 апр в 16:52

Я ещё только осваиваюсь в новом для меня Интернет-пространстве!

Мне бы очень хотелось украсить страничку фотографиями друзей, моей семьи, 
моих коллег.

Пусть каждый из вас прикрепит в комментариях к моей публикации по одному портрету. Не забудьте подписать имя и фамилию моего современника!!!

Анастасия Ефимова 풀

Карл Мария фон Вебер, композитор

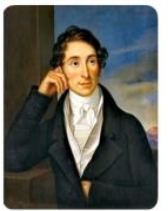

16 апр в 12:53 Ответить

Анна Исакова

Иоганн Вольфганг фон Гёте

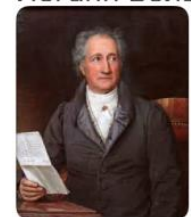

16 апр в 12:53 Ответить

Михаил Лосев

Известный поэт, которому Вы, Феликс, много играли на ф-но. Впоследствии он интересовался Вашими успехами

16 апр в 12:55 Ответить

Анна Исакова

Поэт, который часто бывал у Вас дома, слушал Вашу игру на фортепиано, с ним связаны Ваши лучшие воспоминания юных лет)

16 апр в 12:58 Ответить

Марина Антонова (9)

Ваш дедушка, знаменитый Мозес Мендельсонфилософ, критик

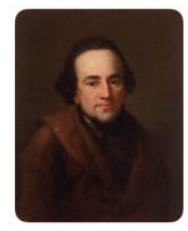

16 апр в 13:04 Ответить
Диана Ткач

Писатель Эрнст Теодор Амадей Гофман

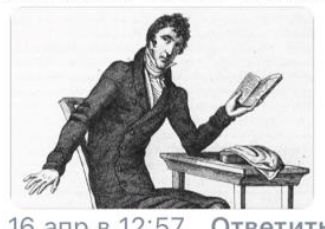

16 апр в 12:57 Ответить

Александра Наполова

Гегель Георг Вильгельм Фридрих

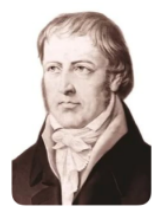

16 апр в 12:54 Ответить

Александра Наполова

он немецкий философ, один из творцов философии немецкого идеализма.

16 апр в 13:03 Ответить

Катя Боярская $\odot$

Генрих Гейне. Поэт

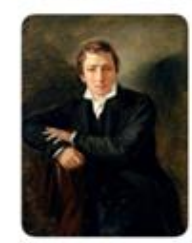

\section{Ответы студентов отделения «Теория музыки»}


Анастасия Наумова

Иоганн Вольфганг фон Гёте поэт, драматург, прозаик, философ, учёный, коллекционер

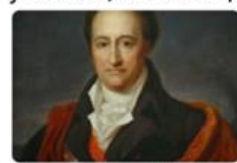

15 апреля в 11:02 Ответить

Алите Прескените ә

Никколо Паганини. Итальянский скрипач, виртуоз, композитор

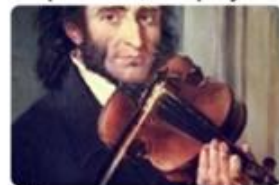

15 апреля в 11:03 Ответить

Виктория Сальникова d

Луиджи Керубини.

Итальянский композитор, педагог

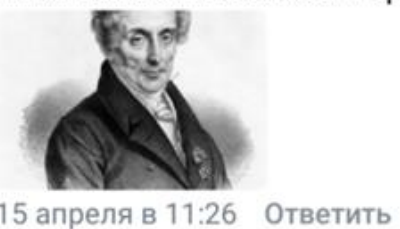

15 апреля в 11:26 Ответить

Таня Ростихина :

Роберт Шуман. Композитор, педагог, музыкальный критик.

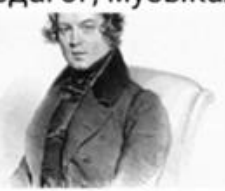

15 апреля в 12:04 Ответить

Елена Сенченко

Гектор Берлиоз. Французский композитор, дирижёр, критик. "Пианистическое искусство

Мендельсона столь же велико, сколь его композиторский гений"

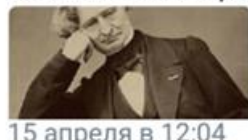

15 апреля в 12:04 Ответить

Maria Pinyasova

Сесиль Жанрено-Мендельсон

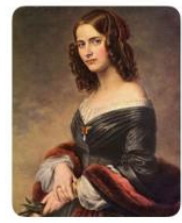

Apr 16 at 7:31 pm Reply

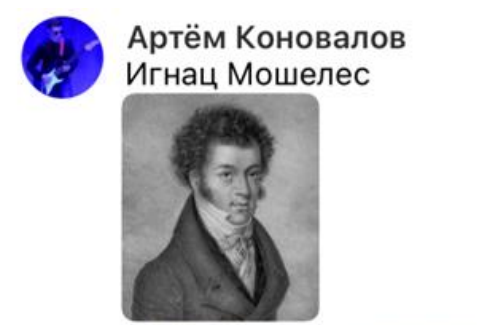

21 апр в 12:37 Ответить

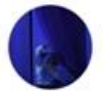

Егор Васильев

Фердинанд Давид

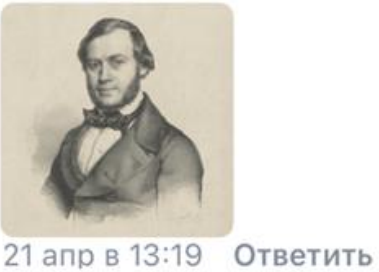

Юра Кофин

Цельтер, Карл Фридрих

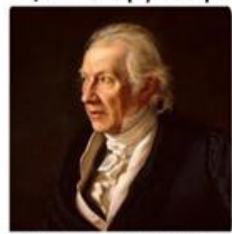

27 апр в 12:44 Ответить

Лина Канзычакова

Михаил Иванович Глинка

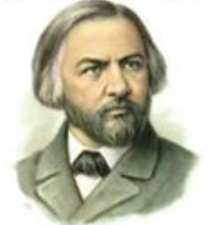

27 апр в 13:06 Ответить

Александр Горелов

Людвиг Бергер

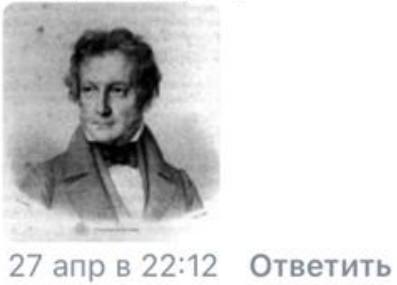

Кирилл Сомов

Эдуард Девриент

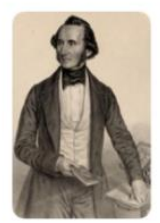

May 7 at 8:53 pm Reply

Ответы студентов отделений «Сольное и хоровое народное пение», «Музыкальное звукооператорское мастерство», «Музыкальное искусство эстрады» 
Jakob-Ludwig-Felix Mendelssohn-Bartholdy

15 апр в 16:53

Когда мне было 12 лет, я познакомился с гением!

В то время я посетил прекрасный город - центр немецкой культуры! Все в этом городе говорит об именах корифеев мировой литературы.

Посмотрите внимательно фотографии и прочитайте описания к ним.

O каком городе идет речь? Какие композиторы также жили в этом городе? Какие произведения они здесь сочиняют? Отправьте мне ваш ответ личным сообщением.

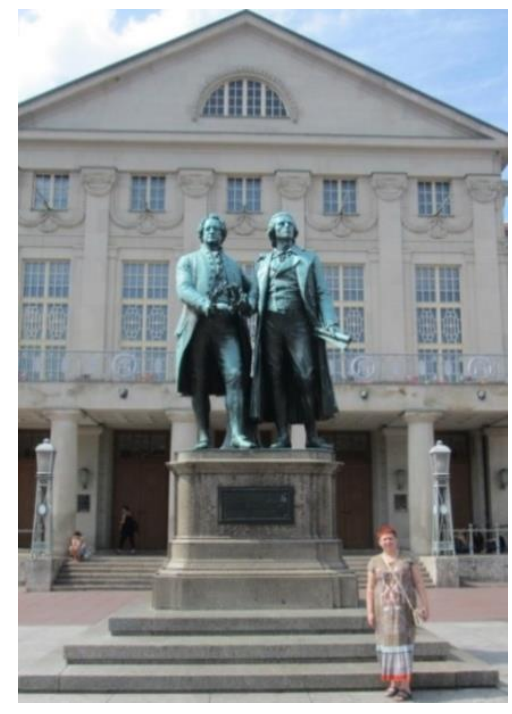

Памятник

Гёте и Шиллеру

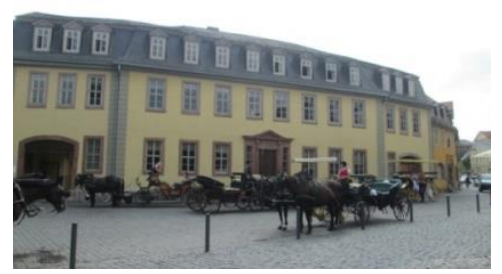

Дом-музей Гёте.

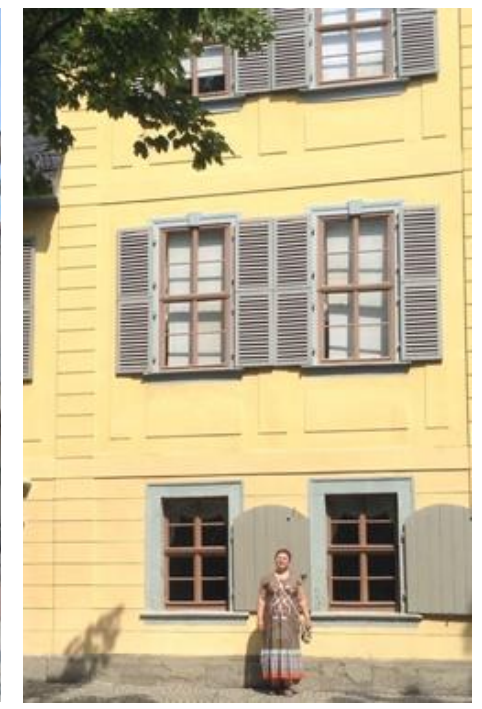

Дом-музей

Шиллера

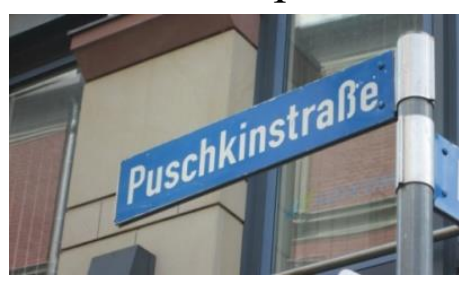

В этом городе есть улица Пушкина!
Город Веймар. Также в этом городе жили Ференц Лист и Иоганн Себастьян Бах работал в Веймаре с марта по июль 1703 и с июля 1708 по 2 декабря 1717 года. В Веймаре Листом были созданы 12 (из 13) симфонических поэм, Тогда же появились 2 программные симфонии «Фауст» и «Данте», новые редакции $2 x$ фортепианных концертов, «Этюдов высшего исполнительского мастерства» и «Этюдов по каприсам Паганини», «Утешения», "Траурное шествие», два тома «Годов странствий», соната си минор, 15 Венгерских рапсодий (из 19-ти), песни и другие сочинения. 
Задания охватывали ключевые события биографии Феликса Мендельсона-Бартольди: о концертных турне композитора, жанрах и сюжетах его произведений, требованиях к репертуару возглавляемых им концертных организаций, роли композитора в истории европейской музыки и т.д.

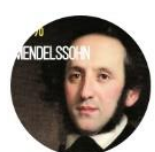

Jakob-Ludwig-Felix Mendelssohn-Bartholdy

15 апр в 16:49

Посмотрите на современные фотографии!!! Если вам когда-то доведется посетить Лейпциг, прогуляйтесь по историческому центру города. Здесь находится церковь Святого Фомы, в которой служил великий Бах! Рядом с ней, в сквере вы обнаружите памятник и моей скромной персоне.

Напишите мне в сообщении, какое событие связывает наши имена? Ведь даже на витражах церкви наши портреты находятся рядом! Опишите это событие.
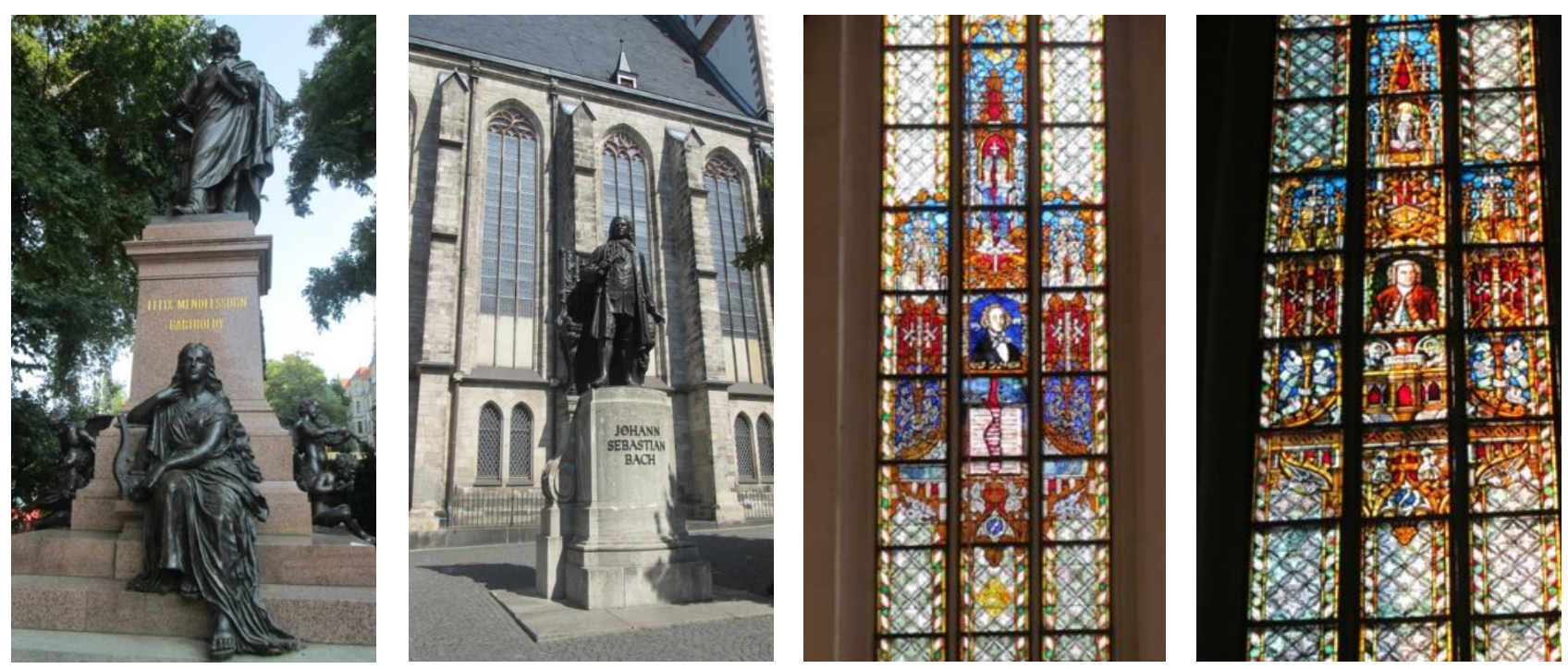
Уважаемый герр, знакомо ли Вам изречение "Если Бах

- Бог, то Мендельсон - его пророк"? Оно именно про Вас, ведь именно Вы смогли дать шанс, и пробудить интерес в глазах публики к творчеству давно забытого, но не менее великого композитора, спустя целых 100 лет. Спусковым крючком послужило исполнение "Страстей по Матфею" 1829 года в Берлине. Никому достоверно, впрочем кроме вас, достоверно неизвестно, где же были найдены эти ноты. Но фактом, который ни одна доселе живая душа не может оспорить, остаётся то, что именно вы дали толчок к возрождению творчества одного из последних композиторов эпохи Барокко.

\author{
Благодаря Вам, возродился \\ интерес к музыке Баха ! \\ После смерти Баха интерес к \\ его музыке пропал. Но в 1829 \\ году в Берлине Вы сыграли его \\ "Страсти по Матфею", которые \\ всех поразили ! В 1850 году \\ было создано "Баховское \\ общество", которое стремилось \\ найти и возродить все рукописи \\ Баха. Спасибо Вам!
}

\section{Ответы Рожковой Юлии, отделение «Оркестровые духовые и ударные инструменты» (слева) и Ткач Дианы, отделение «Теория музки» (справа)}

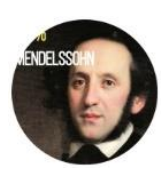

Jakob-Ludwig-Felix Mendelssohn-Bartholdy 15 апр в 16:48

Мне посчастливилось отправиться в путешествие по разным странам Европы! Удивительные впечатления!!! Дикая необузданная природа, величественная архитектура, шедевры скульптуры и живописи!!! Теперь и вы имеете возможность оценить первозданную красоту этих мест, не выходя из дома! Посмотрите небольшой видеосюжет! Попробуйте отгадать, какое мое произведение здесь звучит? Вы не слышали его ранее? Тогда на помощь вам придет учебник! Читайте о моих путешествиях, здесь вы даже найдете описание поездки от лица моего друга. Напишите мне в сообщении, с каким произведением вы познакомились. Чем уникально его жанровое решение? 


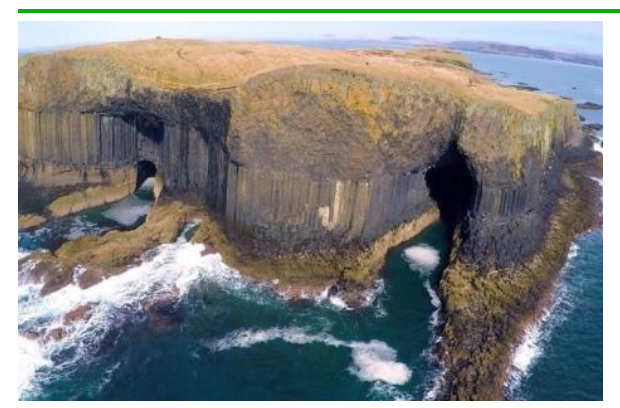

"Фингалова пещера" или "Гебриды"

Самая яркая из шести увертюр, заложила традицию увертюры как особого жанра программной симфонической музыки. Вы предлагаете драматургическое решение, отличное от традиций классической сонатной формы, для которого не важен контраст главной и побочной тем. В основе увертюры лежит волновая драматургия, предполагающая три важных момента времени: начало кульминация - зона спада. При этом каждая новая волна "выше" предыдущей. Все драматургическое развитие увертюры направлено к финальному апофеозу.
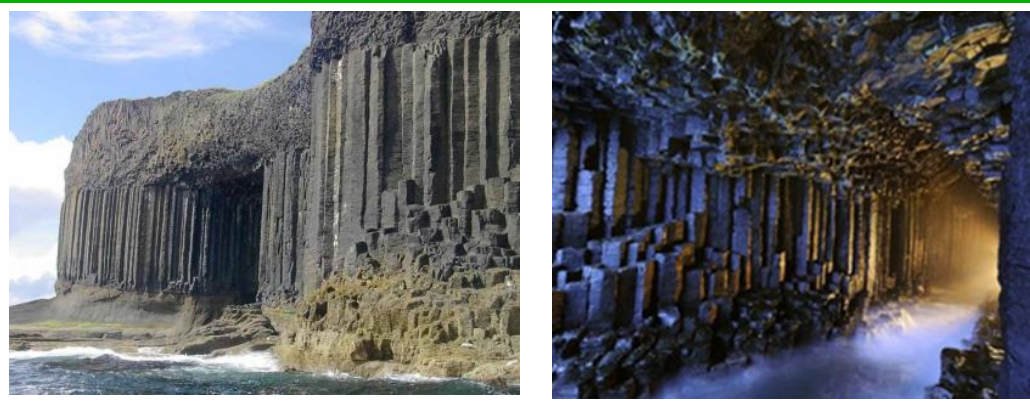

В данном видео фрагменте звучит увертюра «Гебриды, или Фингалова пещера»

Замысел возник во время путешествия в Шотландию в один из Гебридских островов 13:18

Вы описали это в своём письме от 7 августа «чтобы объяснить, какое странное душевное состояние охватило меня»

Я познакомилась с концертной программной увертюрой "Фингалова пещера" (или "Гебриды"). Она уникальна тем, что является самостоятельным концертным произведением

\title{
Ответы Ткач Дианы (слева), Ефимовой Анастасии (справа) отделение «Теория музыки», Кобенко Надежды, отделение «Оркестровые духовые и ударные инструменты» (справа)
}

\author{
Jakob-Ludwig-Felix Mendelssohn-Bartholdy
}

15 апр в 16:47

Мои концертные турне принесли мне немалую пользу. Пусть каждый из вас в комментариях к этой публикации укажет страну или город, какие мне довелось посетить в разные годы (по одному ответу от каждого из вас). 
Александра Наполова

Италия. Париж. Май 1830 года.

16 апр в 12:56 Ответить

Михаил Лосев

Англия - 10 раз

16 апр в 13:06 Ответить

Михаил Лосев

1846 - Бирмингем - премьера "Илии"

16 апр в 13:09 Ответить

Марина Антонова 2

Рим -1830 год. Один из городов путешествия по Европе

16 апр в 13:10 Ответить

Анна Исакова

1829 - турне по Шотландии

16 апр в 13:10 Ответить

Диана Ткач

По возвращении из Италии - Мюнхен

16 апр в 13:16 Ответить

Анастасия Ефимова

Декабрь 1831 Париж

16 апр в 13:21 Ответить
Катя Боярская

1844 год - Англия

16 апр в 13:44 Ответить

Женя Жиденёв :

Шотландия 1829 год

21 апр в 15:24 Ответить

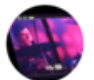

Михаил Вахромеев

Лондон 1832

22 апр в 18:56 Ответить

Андрей Штермер

Италия 1830 года, остров Капри.

27 апр в 12:41 Ответить

Лина Канзычакова

Самое главное его путешествие началось 3 февраля 1809 в Гамбурге :)

27 апр в 14:18 Ответить

Александр Горелов 9

Швейцария 1830

Англия 1829

28 апр в 00:15 Ответить

Юра Кофин

1831-1832

Рим, Швейцария, Мюнхен, Франкфурт-на-Майне, Дюссельдорф, Льеж, Париж, Лондон

1 мая в 17:47 Ответить

\section{Ответы студентов отделений «Теория музыки», «Музыкальное звукооператорское мастерство»}


Maria Pinyasova

Германия, Дюссельдорф

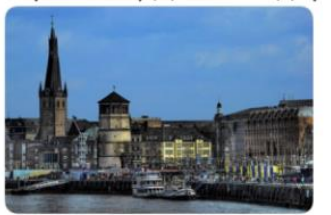

Apr 16 at 7:57 pm Reply

Ramazan Rakhmanov $\odot$ Берлин

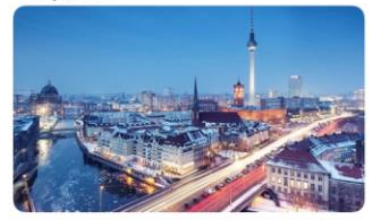

Apr 22 at 11:01 am Reply

Ivan Nichiporchik

Лейпциг.

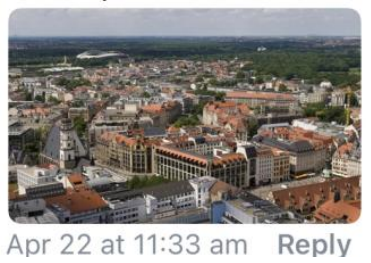

Elizaveta Khalitova

Лондон

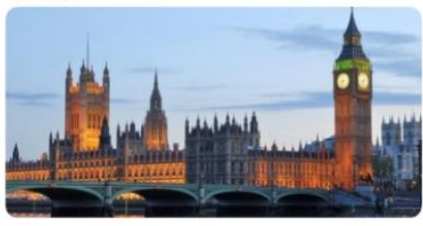

Apr 23 at $12: 25$ am Reply

02

Кирилл Сомов

Париж
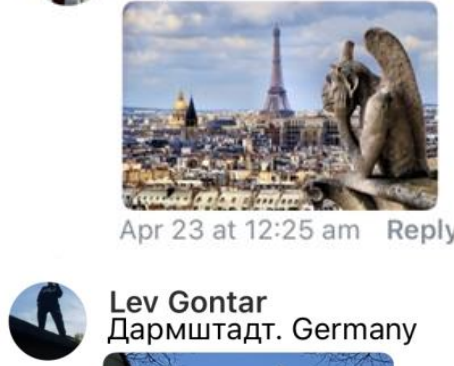

Lev Gontar

Дармштадт. Germany

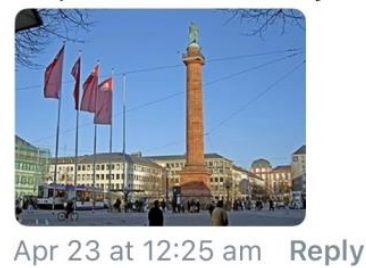

\section{Ответы студентов отделения «Музыкальное искусство эстрады»}

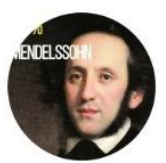

Jakob-Ludwig-Felix Mendelssohn-Bartholdy

15 апр в 16:46

Гектор Берлиоз как-то бросил в мой адрес фразу: «Он чересчур любит покойников». Что же, в этом есть доля правды!

Я всегда пропагандировал музыкальную классику и творчество композиторов предыдущих эпох. Когда я стал директором городской музыки в Дюссельдорфе, их произведения были включены в репертуар муниципальных творческих коллективов. Предлагаю ещё раз переслушать эти произведения и убедиться в моей правоте!

Прикрепите в комментариях к моей публикации аудио треки произведений моих любимых композиторов. По одному фрагменту от каждого из вас! Уверен, у нас получится замечательная «программа концерта»! 
Анна Исакова

12 Blute nur, du liebes Herz

Бах. Страсти по Матфею

16 апр в 13:13 Ответить

Михаил Лосев

(D) Месса папы Марчелло
Палестрина

16 апр в 13:15 Ответить

$7: 39$

02

Диана Ткач

Requiem en Ré mineur, K. 626: Lacrimo...

Wolfgang Amadeus Mozart

2:51

16 апр в 13:17 Ответить

02

(2)

Катя Боярская $\odot$

(1) Symphony No. 9 in D Minor, Op. 125: II....

Ludwig van Beethoven

$12: 00$

16 aпр в 13:46 Ответить

01

Марина Антонова 2

Symphony No. 5 In C Minor Op. 67: I. Al... Ludwig van Beethoven

$7: 53$

16 апр в 13:46 Ответить

01

Elizaveta Khalitova

"Времена года". Весна. №2 Хо... й.Гайдн

Apr 22 at 2:04 am Reply

02
Алите Прескените

Bach, JS: St Matthew Passion, B..

Nikolaus Harnoncourt

5:10

15 апреля в 11:26 Ответить

$\mathrm{O}_{2}$

Анастасия Наумова

D. Увертюра

Вебер-Вольный стрелок

21 апреля в 16:15 Ответить

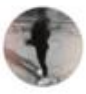

Виктория Сальникова d

D Хор охотников

Вебер

$2: 28$

22 апреля в 9:34 Ответить

01

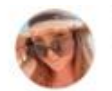

Елена Сенченко

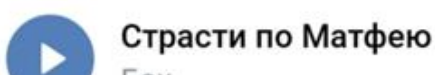

Бах

22 апреля в 12:08 Ответить

Lev Gontar

(1) Une chambre d'hôtel

Mendelson

4:12

Jun 3 at 10:40 am Reply

8 Felix Mendelson-Bartoldi-Mie (다) is के (2)

Jun 3 at 10:19 pm Reply

6. Oksana Ogneva Lev

Лев, है $\Rightarrow$

Jun 3 at 10:21 pm Reply

Ivan Nichiporchik

28. Сотворение мира - III часть...

Йозеф Гайдн (1732-1809) - Берн... 3:57

Apr 22 at 11:37 am Reply

\section{Ответы студентов отделения «Теория музыки», «Сольное и хоровое народное пение», «Музыкальное искусство эстрады»}

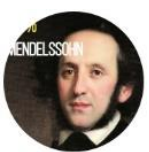

Jakob-Ludwig-Felix Mendelssohn-Bartholdy

15 апр в 16:45

А теперь опять вернемся в Лейпциг и переместимся в Гевандхауз! И здесь я не изменил себе, и этот концертный зал также наполнился звучанием музыки венских классиков и композиторов эпохи барокко.

Кстати! Оцените мою акварель! 
Напишите мне в сообщении, в каком году я занял пост дирижера Гевандхауза, и какие произведения прозвучали под моим управлением?
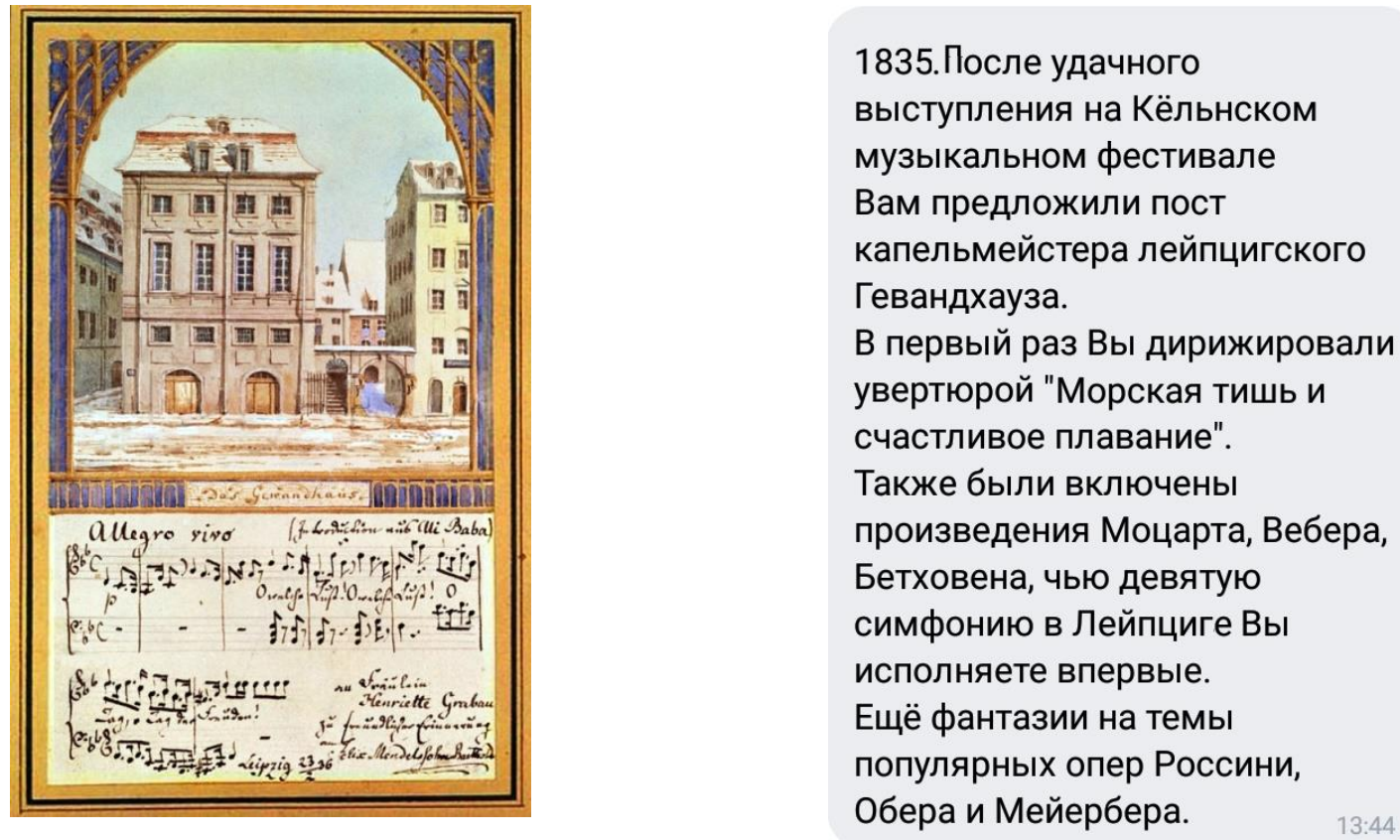

\section{Ответ Ткач Дианы, отделение «Теория музыки»}

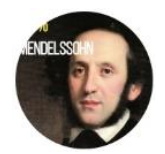

Jakob-Ludwig-Felix Mendelssohn-Bartholdy

15 апр в 16:44

В последнее десятилетие своей жизни я написал произведение, музыка которого и в ваши дни продолжает дарить счастье.

Пусть каждый из вас напишет небольшой комментарий к данной публикации: название и жанр произведения, год создания, автор литературного источника, имена персонажей пьесы, цитаты музыкантов, интересные факты из истории создания произведения и его жизни в последующих веках. 
Юля Рожкова $\odot$

Уильям Шекспир. Вам невероятно точно удалось передать атмосферу сцены!

18 апр в 19:01 Ответить

Надежда Кобенко ๑

"Свадебный Марш", созданный для пьесы "Сон в летнюю ночь" в 1842 году.

18 апр в 22:35 Ответить

\section{Лиза Канташева 응}

23 января 2018 года участники группы Рок-

Синдром выпустили свою версию «Марша Мендельсона» в рок-аранжировке. Композиция вошла в сингл группы Gaudeamus.

24 апр в 11:47 Ответить

\section{Михаил Вахромеев}

В России "Свадебный марш" знали как популярную концертную пьесу и как полковой марш Лейб-гвардии Его Величества Казачьего полка. Так что, бравые казаки-кавалеристы, начиная с русско-турецкой войны 1877 года, маршировали под Мендельсона. Правда, марш звучал в аранжировке для военного оркестра и с другой серединой. https://www.youtube.com/ watch?v=qPPaCgbRyQk

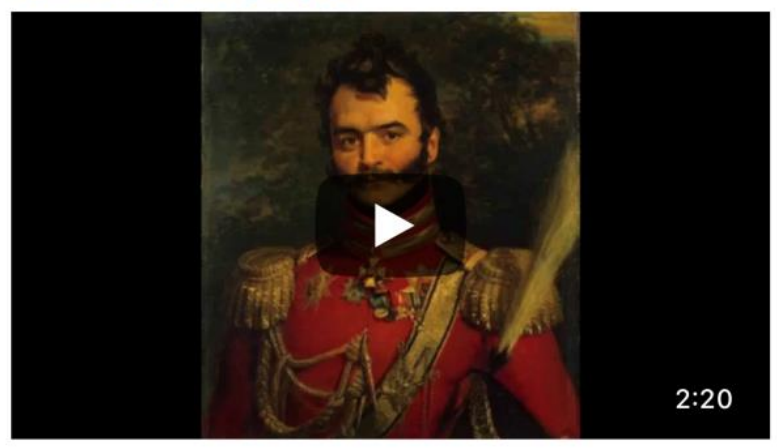

Таня Ростихина Ж

Марш Мендельсона, написан для пьесы «Сон в летнюю ночь», 1842 год.

Традиция сопровождать свадебную церемонию маршем Мендельсона родилась не на родине композитора в Германии, а в Англии, где его музыку очень любили. Первый прецедент был ещё при жизни Мендельсона.

В православной России, где инструментальная музыка запрещена в церкви, свадебный марш никогда не использовался в брачных церемониях. 22 апреля в 0:49 Ответить

\section{Елена Сенченко}

Это один из наиболее

распространённых в мире свадебных маршей.

Написан Ф.Мендельсоном в 1842 году для пьесы «Сон в летнюю ночь». Имена персонажей: Тесей, Эгей, Лизандр, Деметрий, Филострат, Пигва, Мигва, Основа, Дудка, Рыло, Заморыш, Ипполита, Гермия, Елена, Оберон, Титания, Пак, эльфы. 23 апреля в 0:18 Ответить

\section{Ответы студентов отделений «Оркестровые духовые и ударные инструменты», «Сольное и хоровое народное пение», «Музыкальное звукооператорское мастерство»}

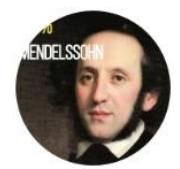

Jakob-Ludwig-Felix Mendelssohn-Bartholdy

15 апр в 16:43

Отличная у меня получается страничка, благодаря вашим стараниям, мои дорогие друзья!

Но я, увы, ещё не совсем на «ты» с новым для меня временем!

Друзья, мне не совсем понятно значение слова «статус» применительно к 
вашим страницам в контакте! Я озадачен! Помогите мне заполнить эту строку! Возможно, вы мне придумаете «статус»?

Напишите свои варианты в комментариях к этой публикации!!!

Александра Наполова

истинный фанат Баха है

16 апр в 13:01 Ответить

Анна Исакова

Бах жив!

16 апр в 13:18 Ответить

(2)

Диана Ткач

Помогу скрепить ваш брачный союз

16 апр в 13:20 Ответить

Михаил Лосев

Феликс - значит "счастливый")))

16 апр в 13:23 Ответить

Анастасия Ефимова

Достану вас, как я достал Баха когда-то 16 апр в 13:29 Ответить

Александра Наполова

Я словно феникс возрождаюсь,

И прошлых композиторов стараюсь

Я вам преподнести во всей красе!

"Но кто же он?!"-вы спросите. Отвечу-

Я Феликс Мендельсон. И знайте все

Я музыкант, я композитор, я маэстро!

16 апр в 14:09 Ответить

3. Диана Ткач Александре

Да Вы поэт !!

16 апр в 14:12 Ответить

(2)

Александра Наполова Диане спасибо)

16 aпр в 14:13 Ответить

Катя Боярская

Хорошая музыка - лучшая таблетка от депрессии.

16 апр в 13:57 Ответить

Elizaveta Khalitova

Самое ценное это слышать и чувствовать.

Apr 23 at 1:43 am Reply

Maria Pinyasova

Принимаю заказы на свадьбы, звонить по номеру 1809-18-47

Apr 16 at 8:07 pm Reply
Надежда Кобенко $\odot$

"О музыке так много говорится и так мало сказано. Я считаю, о ней нельзя рассказать словами, а если бы придерживался противоположного мнения, я перестал бы сочинять музыку."

18 апр в 22:37 Ответить

Юля Рожкова •

"Я ничего так не люблю, как придираться к человеческой природе или таланту; это только угнетает и беспокоит и не приносит ничего хорошего; никто не может прибавить ни локтя к своему росту, все усилия и борьба здесь бесполезны, поэтому нужно молчать об этом и пусть ответственность лежит на Боге."

18 апр в 23:54 Ответить

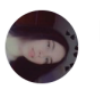

Настя Чурсина है

"Я считаю невозможным сочинять музыку, которая не прочувствована мною вполне; это кажется мне ложью, ибо ноты имеют такой же определённый смысл, как и слова - быть может, ещё более определённый."

19 апр в 08:44 Ответить

Лиза Канташева (20)

"Согласны ли вы со мной, что первым условием художника должно быть уважение к великому, поклонение ему и признание его, а не попытка потушить великое пламя ради того, чтобы зажечь его собственный прожектор ярче?"

24 апр в 11:58 Ответить

Евлампий Шагал

"Даже Цой не настолько жив, как я","Власть над вашими оценками делает меня живее всех живых"

27 апр в 18:08 Ответить

Юра Кофин

Музыка способна оказывать известное воздействие на этическую сторону души; и раз музыка обладает такими свойствами, то, очевидно, она должна быть включена в число предметов воспитания молодежи.

1 мая в 17:47 Ответить

\section{Ответы студентов отделений «Теория музыки»,} «Оркестровые духовые и ударные инструменты», «Музыкальное искусство эстрады», «Музыкальное звукооператорское мастерство» 


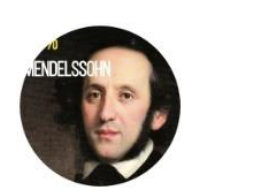

\section{Jakob-Ludwig-Felix Mendelssohn-Bartholdy \\ 15 апр в 16:42}

На этом мое занятие с вами окончено.

Я доволен общением с вами и убедился, что молодость в каждом столетии весела и пытлива).

Мне поведали, что в этом году вашему колледжу исполняется 100 лет!!!

Уверен, что вы гордитесь тем, что учитесь в таком богатом творческими традициями учебном заведении.

Я попробовал поговорить с вами, открыть дверцу в XXI век! У вас столько новых для меня слов! Мне запомнилось одно из них - hashtag!!!

Так и завершу свой пост!

\#студентыккилучшие

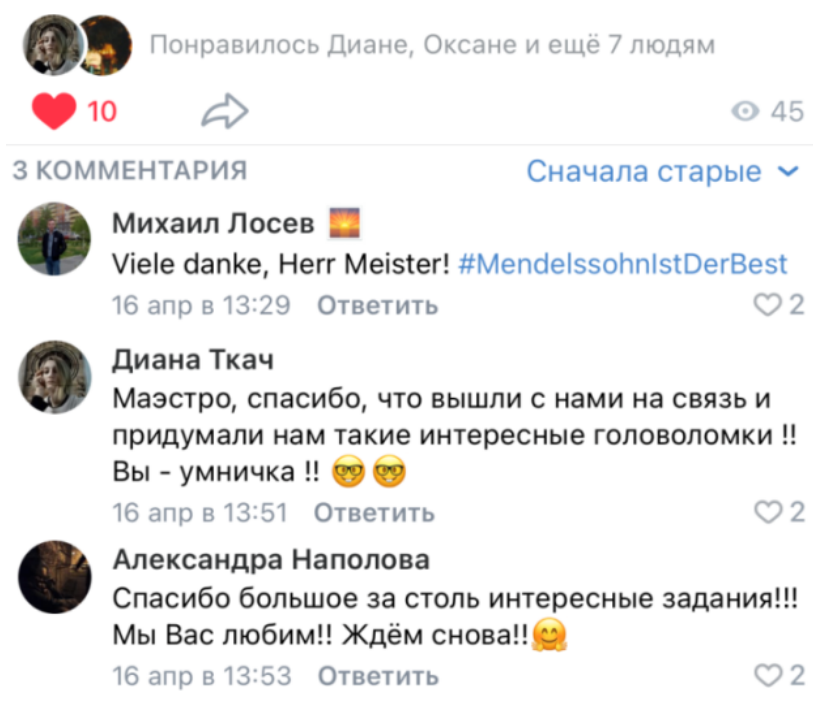

В завершение дистанционного занятия студенты оставили на странице Маэстро свои личные суждения о его творчестве.

\section{Оксана Огнева}

15 апр в 16:41

Дорогие студенты! Я уверена, что вам было интересно общаться с Маэстро! Но, наш сегодняшний гость явно поскромничал, не заполнив поле «О себе». Давайте сделаем это вместе. В комментариях к моей публикации напишите о композиторе!

Чем запомнился вам этот человек? Каково его значение в истории зарубежной музыки? Кто же он, классик или романтик (перечитайте ещё раз лекцию «Романтизм в музыке XIX века»)? Хотелось бы вам посетить его занятия в 


\section{Лейпцигской консерватории? Удивите маэстро своими ответами!}

До встречи на занятиях в колледже!!!

\section{Андрей Штермер}

Больше всего мне господин Феликс Мендельсон-Бартольди запомнился тем, что это именно он написал популярный свадебный марш, а также его пропагандой классики.

И тут собственно вопрос: романтик ли он, или классик? Я считаю, что он один из первых романтиков, которые исполняли классические произведения НЕ КАК КЛАССИКУ, а как романтику, добавив в эти произведения эмоции и создав даже в них внутренний мир, который до этого никак не планировался.

Его значимость в Зарубежной музыке приобрела ценность после его выступлений в Лондоне, которые поразили всех слушателей.

Если бы была такая возможность встретится с господином Феликсом, то я бы с радостью посетил его занятия, чтобы послушать, что в основном говорит и о чем думает романтик.

22 апр в 18:31 Ответить

\section{Женя Жиденёв}

Феликс Мендельсон- это своего рода уникальный человек. С раннего детства его жизнь это музыка.

Значение в Зарубежной музыке, очень весомое, взять только его выступления в Англии, он приехал и покорил Лондон своими выступлениями, да так что через 20 лет Шопен говорил "Что бы иметь большой успех в Лондоне, надо играть Мендельсона".

На вопрос кто же он, классик или романтик, я отвечу так. Он романтик, но так скажем с нотками классицизма, его увлечение композиторами предшественниками дало о себе знать.

Конечно хотелось бы, это же такая честь хотя бы увидеть Мендельсона, а при посещении занятий было бы безусловно здорово перенять маленькую частичку знаний и умений, которыми он обладал.

21 апр в 17:36 Ответить

\section{Ответы студентов отделения «Музыкальное звукооператорское мастерство»}

\section{Lev Gontar}

Если честно, то Феликс Мендельсон запомнился мне именно работой на его странице ведь мы практически прошлись по аспектам всей биографии. Этот опыт был очень разнообразен и интересен! Jun 3 at 11:04 pm Reply

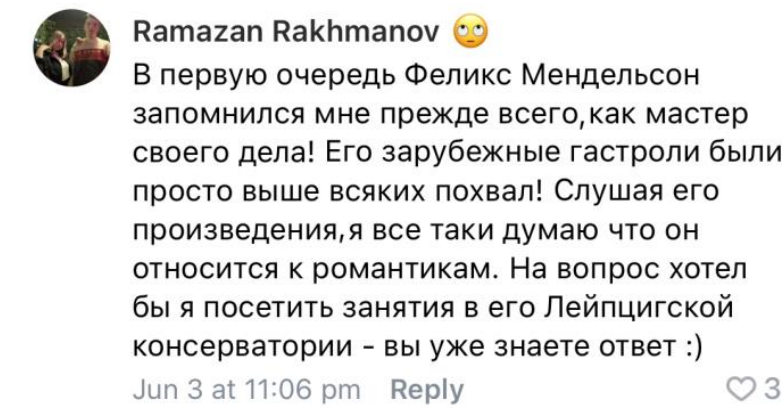

\section{Ответы студентов отделения «Музыкальное искусство эстрады»}




\section{Надежда Кобенко}

Феликс Мендельсон является одним из самых талантливых и плодовитых композиторов, даже те, кто не может назвать ни одного его произведения, знают "Свадебный марш" из музыки к комедии "Сон в летнюю ночь". 11 марта 1829 года Мендельсон дирижировал первым исполнением произведения Иоганна Баха «Страсти по Матфею». Это исполнение дало импульс к возрождению музыки Баха в 19 веке и прославило Мендельсона на весь мир. Также он написал большое количество различных музыкальных произведений. Феликс - классик среди романтиков

19 апр в 00:00 Ответить

Елизавета Наприенко

Кроме склонности к музыке, Мендельсон любил рисовать. Он прекрасно владел карандашом и акварелью, свои письма к друзьям и родным он нередко снабжал рисунками и юмористическими заметками, что свидетельствовало об остроте его ума и веселом нраве.

6 июн в 00:38 Ответить

\section{Юля Рожкова •}

Композитор, умело сочетающий новаторство и эмоциональную составляющую романтического стиля и строгость классики, разносторонне развитый человек, талантливый не только в музыке, но и в изобразительном искусстве. Именно таким предстал передо мной Феликс Мендельсон. Его неповторимый музыкальный стиль можно сравнить с акварельными пейзажами, которые он так любил писать. 6 июн в 03:57 Ответить
Лина Канзычакова

Я считаю его настоящим романтиком, ведь его музыка преисполнена людскими чувствами, простыми, не сложными. Его музыка понятна, конечно есть произведения относящие нас назад, к классицизму, но не без этого. Ведь классика прародитель романтизма. Я думаю любой человек творчества, никогда бы не отказался от урока с ним.

27 апр в 14:42 Ответить

\section{Артём Коновалов}

Мендельсон - личность очень многогранная помимо композиторской деятельности, он был дирижером и исполнителем. Его музыка не может не покорять наши сердца. Из всех его произведений особо отчётливо мне запомнилась увертюра для комедии Шекспира "Сон в летнюю ночь")

20 мая в 19:13 Ответить

Александр Горелов

Феликс Мендельсон - настоящий Моцарт своего века, «примеряющий» противоречия как костюмы, даётся это ему с легкостью! Очень яркий представитель Шумановского поколения. В конце концов он утёр нос всем, кто не верил в него и всячески насмехался над ним в начале. 3 июн в 20:43 Ответить

\section{Ответы студентов отделений «Оркестровые духовые и ударные инструменты», «Музыкальное звукооператорское мастерство»}


Александра Наполова

Феликс Мендельсон романтический классик)) Это обусловлено тем, что композитор открывал новые пути романтического искусства, оставаясь при этом наиболее уравновешенным и классически строгим. Музыка композитора совместила в себе величавую элегичность классицизма и эмоциональность романтизма. И всё это укладывается в рамки строгой формы. Да, и сами современники называли композитора «Классик среди романтиков» 16 апр в 13:06 Ответить

Марина Антонова е

Среди современных ему романтиков он занимает особое место. Его музыка, развиваясь в русле романтизма, теснейшим образом связана с классическими традициями. Классическое и романтическое начала составляют в ней удивительно гармоничный сплав, который проявляется в каждом конкретном случае посвоему. И именно это единство определило образный строй его произведений уравновешенный, жизнеутверждающий и гармоничный. Для великого Маэстро, в отличие от других романтиков, не характерна трагическая конфликтность, в его творчестве нет ощущения непримиримого разлада с окружающей действительностью. Его искусство освещено верой в человека и человеческий разум.

16 апр в 14:01 Ответить

Диана Ткач

Возродил музыку Баха, в качестве дирижёра под его управлением были впервые исполнены сочинения Баха, Генделя и "Большая" домажорная симфония Шуберта.
Анна Исакова

Классико-романтик) В его творчестве присутствуют романтические образы (картины одушевленной природы, зарисовки жизни народа), но это уравновешивается классической стройной формой. Его музыка взволнованна, светла и лирична. Композитор писал для широкого круга любителей, и не отделял себя от слушателя)

$$
16 \text { апр в 13:24 Ответить О3 }
$$

Анастасия Ефимова

Данный композитор, как мне кажется, примыкает к крылу немецкого романтизма ведущего свое начало от Вебера. Характерная для Вебера сказочность и фантастика, одушевленный мир природы, поэзия далеких легенд и сказаний, обновленная и расширенная, переливается в музыке Мендельсона заново найденными красочными тонами.

16 апр в 13:33 Ответить

Михаил Лосев

Добрый и светлый романтик, лирик, в его фантастике нет той веберовской демонической фантастики, как в "Волшебном Стрелке". А его "Песни без слов" - лучший образец его фортепианных сочинений: никакого виртуозничества (к которому композитор относился негативно)

Песня без слов g-moll (6)

Феликс Мендельсон

\section{Ответы студентов отделения «Теория музыки»}

Всем нам известна книга Ольги Пантелеевны Камозиной «Неправильная музыкальная литература. История музыки: первый год обучения». В подобном ключе были выстроены творческие задания и для студентов первого курса. Обращение к разнообразным формам работы в период дистанционного обучения позволило эффективно организовать активность учащихся, повысить их мотивацию к изучению дисциплины и сформировать уважительное отношение молодежи к творческому наследию музыкантов различных эпох.

Об этом душевно и красноречиво свидетельствуют признания студентов в личных сообщениях к Маэстро! 


\section{Список литературы}

1. Огнева О.Г. «Неправильная музыкальная литература» не только детям. Из опыта проведения занятий со студентами в период дистанционного обучения // Сборник статей Международного искусствоведческого форума (26 октября 2020 г.) - Петрозаводск : МЦНП «Новая наука», 2020. - С58-70.

(C) О.Г. Огнева, 2020 


\section{ИНКЛЮЗИВНОЕ ОБРАЗОВАНИЕ: ГЕНЕЗИС И ПРОБЛЕМЫ ВНЕДРЕНИЯ В УСЛОВИЯХ ДАГЕСТАНА}

Феталиева Лаура Платовна к.ф.н. доцент

Рамазнова Эльмира Алиевна к.П.н., доцент

Сантуева Элен Зайдхановна к.ф.н., доцент

ФГБОУ ВО «ДГПУ» г. Махачкала

Инклюзивное обучение сегодня в научно-педагогической литературе рассматривается как процесс обучения детей с особыми образовательными потребностями в общеобразовательных школах.

В настоящее время национальная образовательная политика в нашей стране нацелена на создание оптимальных условий, для включения детей с ограниченными возможностями здоровья в общеобразовательные учреждения, развитие инклюзивного обучения. Это нашло отражение в законе «Об образовании РФ», федеральной целевой программе «Доступная среда» (20112015 гг.); Федеральном государственном образовательном стандарте начального образования, где в документе всего сорок страниц, а словосочетания «дети с ограниченными возможностями здоровья» в тексте встречается семнадцать раз. Это говорит о том, что повышенный интерес проявляется к детям с особыми образовательными потребностями. Развитие инклюзивного образования нашло отражение в национальной стратегииинициативе «Наша новая школа», которые ориентируют систему образования на обеспечение успешной социализации детей с ограниченными возможностями здоровья и определяют условия инклюзивного образования в общей школе.

Зарождение идей инклюзивного обучения в России просматривается в Концепции интегрированного обучения лиц с ограниченными возможностями здоровья (со специальными образовательными потребностями), разработанной в Институте коррекционной педагогики РАО. Российскими учеными Института проблем интегративного (инклюзивного) образования при Московском городском психолого-педагогическом университете ведутся прикладные научные исследования в области инклюзивной образовательной практики.

В профессиональном стандарте педагога одной из его компетенций 
рассматривается способность обучать детей с особыми образовательными потребностями.

В связи с указанными обстоятельствами возникает необходимость подготовки будущих учителей к реализации задач инклюзивного обучения в общеобразовательной школе.

Психологами и педагогами доказано, что отношения и взаимодействие здоровых детей со сверстниками с ограниченными возможностями здоровья являются важнейшим фактором, обеспечивающим успешность инклюзивного обучения (С.В. Алехина, Л.Н. Давыдова, Ю.М. Забродин, Э.И. Леонгард, Д.М. Маллаев, Н.Н. Малофеев. Н.Н. Назарова, Л.М. Шипицына, Н.Д. Шматко) $[1,2,3,4,5]$.

Методику работы с детьми ограниченными возможностями здоровья (OB3) описаны в трудах В.В. Линькова, Н.Н. Малофеева, Н.М. Назарова и др. Они рассматривают различные методы и приёмы организации учебной работы с детьми нарушениями здоровья.

Инклюзивное обучение в младших классах был предметом изучения учёных Т.В. Ахутина, Т.В. Волосовец, Д.С. Ведихова, В.К. Зарецкий, Е.Н. Кутепова, Н.М. Назарова, В.В. Рубцова, Е.В. Самсонова, М.М. Семаго, Е.Н. Сороколетова, Н.Д. Шматко и др. Они указывают на преимущества инклюзивного образования, на возможные последствия совместного обучения, изучают отношение участников педагогического процесса к инклюзивному образованию. Вместе с тем в их работах нет конкретных рекомендаций как обеспечить преимущества инклюзивного образования, реализовать его возможности детей с ОВ3.

В российской и дагестанской школах накоплен определённый опыт инклюзивного обучения младших школьников. В СШ №4 г. Махачкала функционируют инклюзивные классы. Создаются условия для совместного обучения, педагоги накапливают опыт обучения детей с особыми образовательными потребностями.

Учителя, работающие в инклюзивных классах, испытывают значительные трудности в реализации задач инклюзии. Во многом они связаны с отсутствием социальных условий, соответствующей литературы, доступности для детей с OB3 к среде общеобразовательной организации.

В теории и практике инклюзивного обучения младших классов сложились противоречия между: 
- достоинствами, возможностями инклюзивного обучения и его реализацией в практике работы школ;

- требованиями к учителю начальной школы, привлекаемого к решению задач инклюзивного обучения, и его недостаточной педагогической, методической подготовки;

- необходимыми условиями среды инклюзивного обучения и его её реальным состоянием в массовой школе.

Эти противоречия обусловлены следующими причинами:

- инклюзивное обучение не стал предметом специального изучения психологов, методистов;

- не разработаны учебно-методические комплексы работы с детьми разными отклонениями здоровья и развития;

- недостаточной квалификацией учителей начальных классов.

Основная проблема заключается в отсутствии научно-обоснованных технологий инклюзивного обучения и условий их реализации в общеобразовательной школе.

Для решения указанной проблемы выбрана тема исследовательской работы «Технология инклюзивного обучения младших школьников».

Объект исследования - процесс инклюзивного обучения младших школьников.

Предмет исследования - условия реализации инклюзивного обучения в младших классах общеобразовательной школы.

Цель исследования - теоретически обосновать и экспериментально проверить условия реализации инклюзивного образования в младших классах.

Гипотеза исследования - условия реализации инклюзивного образования в начальной школе будет более эффективной, если будут соблюдены следующие условия:

- разработан учебно-методический комплекс совместного обучения учащихся с OB3;

- определены меры социальной и психологической поддержки детей с особыми образовательными потребностями;

- изучены индивидуальные особенности детей с различными нарушениями в развитии.

Цель и выдвинутая гипотеза обусловили необходимость решения следующих задач исследования: 
1. Выявить сущность, цели и задачи инклюзивного обучения младших школьников.

2. Изучить теорию и практику инклюзивного обучения младших школьников в Российской школе. Обосновать модели инклюзивного образования учащихся начальной школы

3. Разработать условия реализации инклюзивного обучения в младших классах общеобразовательной школы.

4. Экспериментально обосновать условия реализации инклюзивного обучения младших школьников.

Практическая значимость заключается в том, что результаты исследования могут быть использованы учителями начальных классов в образовательной практике инклюзивных классов начальной школы. Данные ВКР могут быть полезны для составителей учебно-методических материалов, связанных с обучением детей ОВ3.

Нами определена сущность инклюзивного обучения, его цели и задачи, условия осуществления инклюзивного обучения в младших классах общеобразовательной школы; представлены этапы истории развития обучения детей с особыми образовательными потребностями, рассматриваются различные модели обучения детей с ограниченными возможностями здоровья. Выявлена значимость инклюзивного обучения детей с проблемами здоровья, описаны возможности и преимущества инклюзии. Обоснованы достоинства инклюзивного обучения детей в общеобразовательной школе.

Существующие в настоящее время модели обучения детей с особыми образовательными потребностями не в полной мере обеспечивают выбор родителей и не позволяют реализовывать преимущества инклюзивного образования. Это проблема огромного масштаба, для решения которой нужны усилия:

- государства по созданию соответствующей инфраструктуры в общеобразовательных учреждениях;

- органов управления образованием педагогических образовательных организаций - по подготовке и переподготовке специалистов (психолога, воспитателя, дефектолога, логопеда, тьютора) и учителей;

- образовательных организаций - по разработке нормативно-правовой и учебно-методической документации по инклюзивному обучению;

- педагогов - по усвоению технологий инклюзивного обучения; 
- родителей - по дошкольной подготовке детей с ОВ3 к обучению в общеобразовательной школе и дополнительной помощи им в усвоении учебных программ школы.

С цุелью проверки влияния условий на эффективность инклюзивного обучения учащихся младших классов была организована опытноэкспериментальная работа в средней общеобразовательной школе №4 г. Махачкалы. Эксперимент проводился в 4 «а» классе, где обучается 31 детей, из них 2 с отклонениями здоровья - детский церебральный паралич (ДЦП).

Задачи эксперимента:

- создать нормативно-правовые основы моделей инклюзивного обучения учащихся младших классов;

- разработать методическое обеспечение инклюзивного обучения детей младшего школьного возраста;

- проверить режим организации образовательного процесса для инклюзивного обучения;

- создать технологию психолого-педагогического сопровождения детей с OB3;

- проверить мотивацию родителей и учителей, привлечённых к работе в инклюзивном классе.

Эксперимент проводился в 3 этапа. На первом констатирующем этапе изучалась мотивация родителей и учителей, привлечённых к учебной работе в инклюзивном классе, организационные основы инклюзивного обучения в экспериментальном классе, личные дела учащихся, учебно-методические материалы педагогов, велись наблюдения за школьниками, проводились замеры успешности освоения учебных программ. В ходе констатирующего эксперимента выявлялись сложности и трудности в организации инклюзивного обучения школьников, сопоставлялись нормативные требования к условиям инклюзивного обучения и их реализация в образовательной практике.

В ходе констатирующего этапа педагогического эксперимента было установлено, какие из условий успешного осуществления инклюзивного обучения реализуется в МБГОУ «Общеобразовательная школа №4 г. Махачкалы». 
Таблица 1

Реализация условий инклюзивного обучения в экспериментальном классе

\begin{tabular}{|c|c|c|c|}
\hline №п/П & Условия & Должно быть & Наличие \\
\hline 1. & $\begin{array}{l}\text { Нормативно-правое } \\
\text { обеспечение }\end{array}$ & $\begin{array}{l}\text { - положение об инклюзивном обучении; } \\
\text { - правила приёма детей в инклюзивный класс; } \\
\text { - положение о контроле знаний и умений } \\
\text { учащихся в инклюзивном классе }\end{array}$ & $\begin{array}{l}- \\
- \\
-\end{array}$ \\
\hline 2. & $\begin{array}{l}\text { Учебно-методическое } \\
\text { обеспечение }\end{array}$ & $\begin{array}{l}\text { - методическое оснащение инклюзивного } \\
\text { образовательного процесса; } \\
\text { - адаптированная образовательная программа; } \\
\text { - специальная учебно-методическая } \\
\text { литература; } \\
\text { - индивидуальный учебный план; } \\
\text { - тематическое планирование; } \\
\text { - дидактический материал; } \\
\text { - раздаточный материал; } \\
\text { - технологические карты; } \\
\text { - конспекты уроков; } \\
\text { - конспекты индивидуальных коррекционных } \\
\text { занятий; } \\
\text { - специальных технических средств обучения }\end{array}$ & $\begin{array}{l}- \\
- \\
- \\
- \\
- \\
- \\
-\end{array}$ \\
\hline 3. & $\begin{array}{l}\text { Материально- } \\
\text { техническое } \\
\text { обеспечение }\end{array}$ & $\begin{array}{l}\text {-доступ в школьные помещения; } \\
\text { - кабинеты для специальных занятий; } \\
\text { - медицинский кабинет; } \\
\text { - столовая; } \\
\text { - школьная библиотека; } \\
\text { - спортивный зал; } \\
\text { - школьная раздевалка; } \\
\text { - школьный туалет; } \\
\text { - транспорт для детей; } \\
\text { - пандус; } \\
\text { - подъемник }\end{array}$ & $\begin{array}{l}- \\
- \\
+ \\
+ \\
+ \\
+ \\
+ \\
+ \\
- \\
+ \\
-\end{array}$ \\
\hline 4. & Кадровое обеспечение & $\begin{array}{l}\text { - координатор; } \\
\text { - тьютор; } \\
\text { - воспитатель; } \\
\text { - психолог; } \\
\text { - логопед; } \\
\text { - дефектолог } \\
\text { - социальный педагог }\end{array}$ & $\begin{array}{l}- \\
- \\
+ \\
+ \\
+ \\
+ \\
+\end{array}$ \\
\hline
\end{tabular}




\begin{tabular}{|c|c|c|c|}
\hline 5. & $\begin{array}{l}\text { Профессиональная } \\
\text { подготовка } \\
\text { педагогических } \\
\text { работников }\end{array}$ & $\begin{array}{l}\text { - информационная готовность; } \\
\text { - владение педагогическими технологиями; } \\
\text { - знание основ психологии и коррекционной } \\
\text { педагогики; } \\
\text { - знание индивидуальных отличий детей; } \\
\text { - готовность педагогов моделировать урок и } \\
\text { использовать вариативность в процессе } \\
\text { обучения; } \\
\text { - знание индивидуальных особенностей детей с } \\
\text { различными нарушениями в развитии; } \\
\text { - готовность к профессиональному } \\
\text { взаимодействию и обучению; структура } \\
\text { психологической готовности; } \\
\text { - мотивация учителей; } \\
\text { - эмоциональное принятие детей с различными } \\
\text { типами нарушений в развитии (принятие- } \\
\text { отторжение); } \\
\text { - готовность включать детей с различными } \\
\text { типами нарушений в деятельность на уроке } \\
\text { (включение-изоляция); } \\
\text { - удовлетворенность собственной } \\
\text { педагогической деятельностью }\end{array}$ & $\begin{array}{l}- \\
- \\
-\end{array}$ \\
\hline
\end{tabular}

Анализ данных таблицы 1 «Реализация условий инклюзивного обучения в экспериментальном классе» показывает, что в общеобразовательной школе №4 г. Махачкалы нет нормативно-правового и учебно-методического обеспечения. Условия, связанные с материально-техническим обеспечением, судя по данным таблицы№1, в школе, в основном, не созданы. Вместе с тем дополнительное их изучение свидетельствует о том, что школьные туалеты, раздевалки, спортивные залы общего назначения не приспособлены для использования потребностей детей с ОВ3. Школьные помещения доступны для детей с нарушениями здоровья.

Из необходимого педагогического персонала в школе нет координатора и тьютора.

Больше всего удивил факт отсутствия профессиональной подготовки педагогических работников, привлеченных к учебно-воспитательной работе в инклюзивном классе. Ни один из параметров условий из этой категории не реализован. Как показывает анализ литературы и изучение опыта педагогические достижения учащихся в большинстве своем связаны 
исключительно с профессиональной квалификацией педагогов. В связи с этим был проведен более глубокий анализ профессиональной квалификации представителей администрации и учителей общеобразовательных школ с помощью бесед и анкетирования. Результаты анкетирования характеризуют отношение респондентов к инклюзивному обучению, их мотивацию к работе с детьми нарушениями здоровья.

Для получения более достоверной информации опросом было охвачено более 75 человек, работающих в начальных классах школ г. Махачкалы.

Подавляющее большинство опрошенных трудности внедрения совместного обучения связывают с недостаточной осведомленностью учителей школ в данной области. Об этом свидетельствуют ответы на первый вопрос «Как Вы понимаете инклюзивное образование?». Только 23,7 \% опршенных знают о том, что это обучение детей с ОВЗ в одном классе с обычными детьми; такой же процент опрошенных связывает инклюзивное образование с наличием детей-инвалидов в одном классе с обычными детьми; 39,5 \% думают, что это создание специального коррекционного класса для детей с ОВ3 в массовой школе; а 13,1 \% — вообще не смогли ответить на данный вопрос.

Второй вопрос «Насколько Вы знакомы с основными положениями и принципами инклюзивного образования?» был направлен на выявление информационной осведомленности учителей об основных положениях и принципах инклюзивного образования. Данные показывают, что только 13,1 \% респондентов знакомы с основными положениями и принципами инклюзивного образования; 23,7 \% - дали отрицательный ответ «не знакомы». Свыше половины опрошенных $(63,2$ \%) имеют недостаточную информацию по этому вопросу.

Третий вопрос предполагал выявление у педагогов школ наличия опыта работы с детьми с ОВ3? Как выяснилось, большая часть (65,8 \%) учителей начальной школы не имеют такого опыта работы; 13,1 \% — работали раньше; $15,8 \%$ - работают в настоящее время, а 5,3 \% — собираются начать работать в ближайшее время. Не секрет, что в настоящее время отношение к инклюзивному обучению в педагогическом сообществе неоднозначно. Поэтому нам было интересно знать мнение учителей о том, где лучше и эффективнее обучать детей с ОВЗ и детей-инвалидов? Половина (50 \%) респондентов считает, что это лучше делать на базе специализированных коррекционных учреждений; на базе специализированных школ-интернатов и на дому - по 18,4 \% соответственно. Только один из десяти (10,5\%) педагогов уверен, что 
детям с ОВ3 нужно учиться на базе общеобразовательных школ в обычном классе (инклюзивные классы). Затруднились ответить на этот вопрос - 2,6 \%.

Анализ ответов на вопрос «Как Вы относитесь к возможности совместного обучения детей с нарушениями развития?» показал, что каждый пятый $(21,1$ \%) учитель уверен, что инклюзия в принципе невозможна; 26,3% - допускают такую возможность, но считают, что общество к этому еще не готово; примерно третья часть респондентов $(31,6 \%)$ видят необходимость введения инклюзивного обучения, но думают, что в системе образования должны произойти кардинальные изменения; 10,5 \% учителей согласны, что это неизбежно, но предвидят много сложностей на этом пути; 2,6 \% затруднились дать ответ. Нас удивила позиция некоторых учителей (7,9%), сказавших, что к реализации инклюзии уже сейчас нет никаких препятствий. Характер подобных ответов, скорее всего связан с отсутствием у данной части педагогов глубокого понимания проблем инклюзивного образования. Важным условием инклюзивного образования является осведомленность учителей в особенностях развития детей с различными видами нарушений. Анализ ответов показал наличие значительного дефицита знаний анкетируемых в области специальной (коррекционной) педагогики и психологии. Результаты анкетирования отражены в таблице.

Таблица 2

Осведомленность учителей в особенностях развития детей с различными видами нарушений

\begin{tabular}{|l|c|c|c|c|c|}
\hline \multirow{2}{*}{ Виды нарушений } & \multicolumn{5}{|c|}{ Знакомы с видами нарушений (в\%) } \\
\cline { 2 - 6 } & $\begin{array}{c}\text { В рамках } \\
\text { программы } \\
\text { Вуза }\end{array}$ & $\begin{array}{c}\text { В рамках } \\
\text { программы } \\
\text { школы }\end{array}$ & $\begin{array}{l}\text { Проходил } \\
\text { курсы ПК }\end{array}$ & $\begin{array}{c}\text { Участвовал } \\
\text { в } \\
\text { семинарах }\end{array}$ & $\begin{array}{c}\text { Необходимо } \\
\text { специальное } \\
\text { обучение }\end{array}$ \\
\hline $\begin{array}{l}\text { Ребенок } \\
\text { нарушением } \\
\text { поведения }\end{array}$ & 39,5 & 15,6 & 23,7 & 10,5 & 44,7 \\
\hline Нарушения речи & 39,5 & 15,6 & 15,6 & 23,7 & 50 \\
\hline $\begin{array}{l}\text { Интеллектуальные } \\
\text { нарушения }\end{array}$ & 36,8 & 15,6 & 13,1 & 15,6 & 52,6 \\
\hline Нарушения слуха & 31,6 & 15,6 & 5,3 & 10,5 & 60,5 \\
\hline Нарушения зрения & 31,6 & 15,6 & 10,5 & 10,5 & 57,9 \\
\hline $\begin{array}{l}\text { Двигательные } \\
\text { нарушения }\end{array}$ & 31,6 & 15,6 & 13,1 & 10,5 & 57,9 \\
\hline
\end{tabular}


Как видно из таблицы 2 большинство опрошенных ответили, что знакомы с основами коррекционной педагогики и специальной психологии в рамках программы вуза или педагогического колледжа.

Незначительный процент учителей проходили курсы повышения квалификации (от 5,3 \% до 23,7 \%) и участвовали в семинарах (от 10,5 \% до 23,7 \%). Подавляющее большинство опрошенных (от 44,7 \% до 60,5 \%) признают, что им необходимо дополнительное обучение по вопросам коррекционной педагогики и психологии. Наименее всего учителя осведомлены о детях с сенсорными нарушениями: слуха и зрения.

Отношение к возможности совместного обучения зависит от ведущего дефекта в структуре нарушений развития ребенка. Так, например, 44,7 \% педагогов считают, что нарушения опорно-двигательного аппарата у ребенка не являются препятствием к его обучению в общеобразовательной школе. О возможности совместного обучения детей с нарушениями речи говорят примерно около половины $(47,4 \%)$ опрошенных. Такой же процент респондентов не видит препятствий к обучению в общей школе детей с нарушением поведения. Дети с интеллектуальными нарушениями, по мнению 31,6 \% опрошенных, также могут обучаться с обычными детьми. Дети с нарушениями слуха и зрения почти одинаково оцениваются с точки зрения возможности включения их в обучение в массовой школе: 26,3% и 23,7 \% соответственно. 2,6 \% опрошенных считают, что в массовой школе могут обучаться все категории детей с ОВ3 без исключения. 2,6 \% респондентов затруднились дать ответ.

На вопрос «С какими категориями детей Вы лично могли бы начать работать?» анкетируемые дали следующие ответы: ребенок с нарушением поведения — 57,9 \%, нарушения речи — 31,6 \%; интеллектуальные нарушения — 28,9 \%; нарушения слуха — 5,3 \%; нарушения зрения — 10,5 \%; двигательные нарушения — 34,2 \%; ни с одной из перечисленных выше — 18,4 $\%$.

Тот факт, что на детей с сенсорными нарушениями (слуха) выпало наименьшее количество выборов, по нашему мнению, можно объяснить двумя причинами: во-первых, недостатком специальных знаний в области коррекционных методов обучения таких детей; во-вторых, наличием коммуникативного барьера в работе с такими детьми.

Данные анкетирования хорошо коррелируется с результатами опроса учителей инклюзивных классов СОШ №4 г. Махачкалы. Это позволяет 
утверждать об общих причинах профессиональной неподготовленности учителей к учебно-воспитательной работе в инклюзивных классах. Опросы работников администрации школ, самих учителей в качестве причин несоответствия их квалификации требованиям инклюзивного обучения называют следующие причины:

- отсутствие у учителей опыта инклюзивного обучения;

- недостаточное знание специфики работы с детьми с отставанием в развитии и нарушениями здоровья;

- нехватка специальной и методической литературы;

- нет площадок, центров повышения квалификации учителей и их переподготовки для работы в инклюзивных классах.

Реализация этого решающего условия успешности инклюзивного обучения и устранение указанных причин мы связали с проведением специального обучения педагогов, привлеченных к учебно-воспитательной работе в инклюзивных классах.

Формирующий этап

Программа повышения квалификации (72 часа) приводится в приложении. Она включает в себя следующие темы:

1. Сущность, цели и задачи инклюзивного образования младших школьников.

2. Основные принципы инклюзивного образования.

3. Опыт инклюзивного образования в России и за рубежом.

4. Направления и формы организации инклюзивного образования младших школьников.

5. Условия реализации инклюзивного образования в начальной школе.

6. Технологии инклюзивного образования в начальной школе.

Кроме теоретических занятий были организованы практические занятия, проведены семинары, пробные уроки и их анализ. Занятия в школе проводились с привлечением психологов, специалистов института повышения квалификации, преподавателей ДГПУ. Итоги изучения содержания программы оценивалось тестированием учителей, анализом продуктов их педагогической деятельности и проведенных уроков, а также изменением их мотивации.

Контрольный этап

После проведения ходе формирующего эксперимента обучения были проведены замеры. 
Как показали данные этого анализа, мотивация учителей значительно повысилась. Изъявили желание работать в инклюзивном классе на $36 \%$ больше учителей. Повысилась их осведомленность об особенностях развития детей с различными видами нарушений. Совместное обучение поддержали более 70\% опрошенных учителей. Профессиональные пробы в рамках изучения курса развили у них уверенность о возможностях совместного обучения и его успешности. Кроме того, успешность опытно-экспериментальной работы была оценена нами по итогам успешности освоения учащимися образовательной программы на констатирующем этапе и после завершения формирующего этапа. Данные тестирования учащихся, их оценки сведены в таблицу 3.

Таблица 3

Успешность освоения образовательной программы

\begin{tabular}{|c|c|c|c|c|c|}
\hline \multirow[t]{2}{*}{ Данные } & \multirow{2}{*}{$\begin{array}{c}\text { Общее } \\
\text { количество } \\
\text { учащихся }\end{array}$} & \multicolumn{4}{|c|}{ Учатся } \\
\hline & & на «5» & на «4» & на «3» & на «2» \\
\hline Констатирующий & 31 & 6 & 15 & 8 & 2 \\
\hline Контрольный & 31 & 8 & 20 & 2 & 1 \\
\hline
\end{tabular}

Для количественной оценки успешности освоения программы детьми инклюзивного класса был введён коэффициент успешности обучения - К, который определялся как отношение достигнутого результата учащихся к возможному эталонному уровню

$$
\mathrm{K}=\Pi_{\mathrm{p}} / \Pi_{\ni}
$$

Реализованный уровень $\Pi_{\mathrm{p}}$ определяется как сумма

$$
\sum^{\mathrm{n}} \cdot \Pi_{\mathrm{p}}=\sum^{\mathrm{n}} 5 \cdot \mathrm{n}_{1}+4 \mathrm{n}_{2}+3 \cdot \mathrm{n}_{3}+2 \mathrm{n}_{4},
$$

где $\mathrm{n}_{1}$ - количество учащихся, получивших оценку $5, \mathrm{n}_{2-}$ количество учащихся, получивших оценку $4, \mathrm{n}_{3-}$ количество учащихся получивших оценку $3, \mathrm{n}_{4}$ - количество учащихся получивших оценку 2.

Эталонный уровень $\Pi_{\ni}$ определяется как максимально возможный уровень, который может быть достигнут всем классом и определяется как

$$
\Pi_{\ni}=\sum 5 \cdot \mathrm{n},
$$

где $\mathrm{n}$ - общее количество учащихся.

Используя данные таблицы №3, вычислим К К- коэффициент обученности на констатирующем этапе эксперимента, а $K_{\phi}-$ на формирующем этапе. 
Соответственно коэффициенты успешности обучения на констатирующем $\left(\mathrm{K}_{\mathrm{\kappa}}\right)$ и формирующем $\left(K_{\phi}\right)$ этапах определим по формулам

$$
\begin{aligned}
& \kappa_{\mathrm{K}}=\Pi_{\mathrm{pK}} / \Pi_{3}, \\
& \kappa_{\phi}=\Pi_{\mathrm{p} \phi} / \Pi_{\ni}
\end{aligned}
$$

где $\Pi_{\text {рк }}$ и $\Pi_{\text {рф }}$ - реализованные уровни соответственно на констатирующем и формирующем этапах эксперимента.

Реализованные уровни на констатирующем и формирующем этапах эксперимента равны:

$$
\begin{aligned}
& \Pi_{\text {pк }}=\sum^{\mathrm{n}} \mathrm{n}_{1} \cdot 5+\mathrm{n}_{2} \cdot 4+\mathrm{n}_{3} \cdot 3 \mathrm{n}_{4} \cdot 2=6 \cdot 5+15 \cdot 4+1 \cdot 8+2 \cdot 2=118 \\
& \Pi_{\text {pф }}=\sum^{\mathrm{n}} \mathrm{n}_{1} \cdot 5+\mathrm{n}_{2} \cdot 4+\mathrm{n}_{3} \cdot 3 \mathrm{n}_{4} \cdot 2=8 \cdot 5+20 \cdot 4+2 \cdot 8+2 \cdot 1=138 \\
& \text { Эталонный уровень для обоих этапов равен }
\end{aligned}
$$

$$
\sum^{\mathrm{n}} \mathrm{n} \cdot 5=31 \cdot 5=155
$$

По этим данным вычисляем коэффициенты обученности учащихся на констатирующем и формирующем этапах эксперимента.

$$
\begin{aligned}
& \kappa_{\mathrm{K}}=\Pi_{\mathrm{p}} / \Pi_{\ni}=118 / 155=0,76 \\
& \kappa_{\phi}=\Pi_{\mathrm{p}} / \Pi_{\ni}=138 / 155=0,9
\end{aligned}
$$

Разница в успешности обучения учащихся инклюзивного класса на констатирующем и формирующем этапах составляет

$$
\Delta \mathrm{K}=\mathrm{K}_{\phi}-\mathrm{K}_{\mathrm{K}}=0,9-0,76=0,146
$$

Таким образом, проведенная работа по повышению квалификации учителей, работающих в инклюзивном классе, позволила повысить успеваемость учащихся. По результатам эксперимента может быть сделан вывод о верности нашего предположения, что успешность обучения в инклюзивном классе определяется профессиональной квалификацией педагогического персонала.

Итак, мы разработали условия реализации инклюзивного обучения в младших классах общеобразовательной школы.

Экспериментально обосновали условия реализации инклюзивного обучения младших школьников.

Реализовали уровни и вычислили коэффициенты обученности учащихся на констатирующем, формирующем и контрольном этапах эксперимента.

Реализовано решающее условие успешности инклюзивного обучения с проведением специального обучения педагогов, привлеченных к учебновоспитательной работе в инклюзивных классах. (Программа повышения квалификации -72 часа). 
Реализовали уровни и вычислили коэффициенты обученности учащихся на констатирующем и формирующем этапах эксперимента.

В ходе констатирующего этапа педагогического эксперимента было установлено, какие из условий успешного осуществления инклюзивного обучения реализуется в МБГОУ «Общеобразовательная школа №4 г.Махачкалы». Анализ данных таблицы 1 «Реализация условий инклюзивного обучения в экспериментальном классе» показывает, что в общеобразовательной школе №4 г. Махачкалы нет нормативно-правового и учебно-методического обеспечения. Условия, связанные с материально-техническим обеспечением, судя по данным таблицы№1, в школе, в основном, созданы. Вместе с тем дополнительное их изучение свидетельствует о том, что школьные туалеты, раздевалки, спортивные залы общего назначения не приспособлены для использования потребностей детей с ОВ3. Школьные помещения доступны для детей с нарушениями здоровья.

Из необходимого педагогического персонала в школе нет координатора и тьютора.

Больше всего удивил факт отсутствия профессиональной подготовки педагогических работников, привлеченных к учебно-воспитательной работе в инклюзивном классе. Ни один из параметров условий из этой категории не реализован. Как показывает анализ литературы и изучение опыта педагогические достижения учащихся в большинстве своем связаны исключительно с профессиональной квалификацией педагогов.

На констатирующем этапе были выявлены недостаточные знания учителей и администрации о сути инклюзивного обучения.

В связи с этим на формирующем этапе эксперимента был проведен более глубокий анализ профессиональной квалификации представителей администрации и учителей общеобразовательных школ с помощью бесед и анкетирования. Результаты анкетирования характеризуют отношение респондентов к инклюзивному обучению, их мотивацию к работе с детьми нарушениями здоровья. Была разработана и проведена программа(Приложение).

На контрольном этапе были проведены замеры и выявлена положительная динамика. 


\section{Заключение}

Целью нашего исследования было теоретически обосновать и экспериментально проверить условия реализации инклюзивного образования в младших классах.

Современные тенденции в отечественном образовании, связанные с необходимостью включения детей с ограниченными возможностями здоровья в массовую школу, актуализируют проблему отсутствия научно-обоснованных технологий инклюзивного обучения и условий их реализации в общеобразовательной школе.

Обобщение данных научной литературы показало, что инклюзивное образование обладает комплексом новых возможностей для создания и осуществления условий инклюзивного обучения в младших классах общеобразовательной школы.

В ходе теоретического исследования определена сущность инклюзивного обучения, его цели и задачи, модели реализации, условия осуществления инклюзивного обучения в младших классах общеобразовательной школы.

Проведенное исследование подтвердило выдвинутую гипотезу, позволило решить поставленные задачи и достигнуть цели исследования.

Эксперимент проводился в 3 этапа. На первом констатирующем этапе изучалась мотивация родителей и учителей, привлечённых к учебной работе в инклюзивном классе, организационные основы инклюзивного обучения в экспериментальном классе, личные дела учащихся, учебно-методические материалы педагогов, велись наблюдения за школьниками, проводились замеры успешности освоения учебных программ. В ходе констатирующего эксперимента выявлялись сложности и трудности в организации инклюзивного обучения школьников, сопоставлялись нормативные требования к условиям инклюзивного обучения и их реализация в образовательной практике.

Реализовали уровни и вычислили коэффициенты обученности учащихся на констатирующем и формирующем этапах эксперимента.

В ходе констатирующего этапа педагогического эксперимента было установлено, какие из условий успешного осуществления инклюзивного обучения реализуется в МБГОУ «Общеобразовательная школа №4» г. Махачкалы. Анализ данных таблицы 1 «Реализация условий инклюзивного обучения в экспериментальном классе» показывает, что в общеобразовательной школе №4 г. Махачкалы нет нормативно-правового и учебно-методического обеспечения. Условия, связанные с материально-техническим обеспечением, 
судя по данным таблицы№1, в школе, в основном, созданы. Вместе с тем дополнительное их изучение свидетельствует о том, что школьные туалеты, раздевалки, спортивные залы общего назначения не приспособлены для использования потребностей детей с ОВЗ. Школьные помещения доступны для детей с нарушениями здоровья.

Из необходимого педагогического персонала в школе нет координатора и тьютора.

Больше всего удивил факт отсутствия профессиональной подготовки педагогических работников, привлеченных к учебно-воспитательной работе в инклюзивном классе. Ни один из параметров условий из этой категории не реализован. Как показывает анализ литературы и изучение опыта педагогические достижения учащихся в большинстве своем связаны исключительно с профессиональной квалификацией педагогов.

На констатирующем этапе были выявлены недостаточные знания учителей и администрации о сути инклюзивного обучения.

В связи с этим на формирующеем этапе эксперимента был проведен более глубокий анализ профессиональной квалификации представителей администрации и учителей общеобразовательных школ с помощью бесед и анкетирования. Результаты анкетирования характеризуют отношение респондентов к инклюзивному обучению, их мотивацию к работе с детьми нарушениями здоровья.

Реализация решающего условия успешности инклюзивного обучения и устранение указанных причин мы связали с проведением специального обучения педагогов, привлеченных к учебно-воспитательной работе в инклюзивных классах.

Программа повышения квалификации (72 часа) приводится в приложении.

Успешность освоения образовательной программы показана в таблице №3.

На контрольном этапе были проведены замеры и выявлена положительная динамика.

Значимость полученных результатов проведенного исследования доказана существенным изменением не только количественных, но и качественных показателей. 
Анализ результатов ВКР позволяет утверждать, что проведенное исследование подтвердило выдвинутую гипотезу, позволило решить поставленные задачи и достигнуть цели исследования.

Таким образом, результаты исследовательской работы могут быть использованы учителями начальных классов в образовательной практике инклюзивных классов начальной школы. Полученные данные могут быть полезны для составителей учебно-методических материалов, связанных с обучением детей ОВ3.

\section{Список литературы}

1. Алехина С.В., Семаго Н.Я., Фадина А.К. Инклюзивное образование. Выпуск 1. - М.: Центр «Школьная книга», 2010.

2. Колокольцева М.А. Давыдова Л.Н. Развитие нравственного отношения младшего школьника к сверстникам в процессе инклюзивного образования. / Инклюзивное образование: методология, практика, технология: матер. междунар. науч. конф. - М.: МГППУ, 2011.

3. Малофеев Н.Н. Интегрированное обучение в России: задачи, проблемы и перспективы// Особый ребёнок: исследование и опыт помощи.2000.-вып.3.

4. Назарова Н. Интегрированное (инклюзивное) образование: генезис и проблемы внедрения // Социальная педагогика. - 2010. - № 1.

5. Шипицына Л. М. Интеграция - ведущее направление специального образования в России на рубеже XXI века. - М.: Изд-во МГУП, 2000.

6. Конвенция о правах инвалидов. Краткое изложение основных положений// интернет ресурс Портал для людей с ограниченными возможностями здоровья Dislife/ дежим доступа http://www.dislife.ru/flow/theme/1000.

7. Феталиева Л.П. Опыт инклюзивного образования в России и за рубежом./ Материалы международной конференции «Актуальные проблемы педагогики и психологии начального образования», Махачкала, ДГПУ, 2015.

8. Феталиева Л.П. Преимущества инклюзии. / Материалы международной конференции «Актуальные проблемы педагогики и психологии начального образования», Махачкала, ДГПУ, 2015.

9. Федеральный государственный стандарт начального общего образования. http://mon.gov.ru/pro/fgos/noo/pr_fgos_2009_of_1n_01.pdf. 
МЕТОДОЛОГИЧЕСКИЕ ОСОБЕННОСТИ

СОВРЕМЕННОГО ОБРАЗОВАНИЯ 
УДК 796.413/.418

\title{
МЕТОДОЛОГИЯ ОЦЕНКИ КООРДИНАЦИОННЫХ СПОСОБНОСТЕЙ ЗАНИМАЮЩИХСЯ СПОРТИВНОЙ ГИМНАСТИКОЙ НА ЭТАПЕ НАЧАЛЬНОЙ ПОДГОТОВКИ
}

\author{
Береславская Наталья Вадимовна \\ к.п.н., доцент \\ Жигайлова Лариса Валентиновна \\ к.П.н., доцент \\ Барчо Ольга Федоровна \\ Тронев Вячеслав Вячеславович
}

\begin{abstract}
Аннотация: Проблема развития координационных способностей является одной из актуальных задач физического воспитания и спорта, так как именно это качество способствует развитию умения сохранять равновесие, согласовывать выполняемые движения, дифференцировать прилагаемые усилия, обучаться новым упражнениям.

На современном этапе развития спортивной гимнастики, одновременно с увеличением требований, к качеству подготовки занимающихся, наблюдается тенденция к омоложению состава сборных команд. В связи с этим перед тренерами стоит проблема поиска таких средств и методов, которые бы позволили юным гимнастам в более короткие сроки осваивать все возрастающие по числу и трудности двигательные действия.

Таким образом, рост сложности упражнений в спортивной гимнастике, обусловил разработку научных подходов к системе тренировки, важное место в которой занимает развитие специальных физических качеств на различных этапах многолетней подготовки. Разработка же методики её оценки на начальном этапе позволит оптимизировать подготовку юных гимнастов, опираясь на модельные значения изучаемого качества.

Ключевые слова: координационные способности, спортивная гимнастика, юные гимнасты.
\end{abstract}




\title{
METHODOLOGY FOR ASSESSING THE COORDINATION ABILITIES OF ARTISTIC GYMNAST AT THE INITIAL TRAINING STAGE
}

\section{Bereslavskaya Natalia Vadimovna Zhigailova Larisa Valentinovna Barco Olga Fyodorovna Tronev Vyacheslav Vyacheslavovich}

\begin{abstract}
Problem of developing coordination abilities is one of the urgent tasks of physical education and sports, since it is this quality that contributes to the development of the ability to maintain balance, coordinate the movements performed, differentiate the efforts made, and learn new exercises.

At the present stage of development of sports gymnastics, along with increasing requirements for the quality of training of students, there is a tendency to rejuvenate the composition of national teams. In this regard, the coaches face the problem of finding such tools and methods that would allow young gymnasts to master the increasing number and difficulty of motor actions in a shorter time.

Thus, the increase in the complexity of exercises in gymnastics has led to the development of scientific approaches to the training system, an important place in which is the development of special physical qualities at various stages of long-term training. The development of a methodology for its assessment at the initial stage will optimize the training of young gymnasts, based on the model values of the studied quality.
\end{abstract}

Key words: coordination abilities, sports gymnastics, young gymnasts.

\section{1 Особенности определения и развития координационных способностей в процессе подготовки гимнастов}

Спортивная гимнастика - это вид спорта связанный с выполнением разнообразных сложно-координационных движений, занятия которым способствуют выработке умения преодолевать неуверенность и скованность в своих движениях и управлять ими, а так же содействуют развитию координации и согласованности действий при выполнении упражнений, элементов и связок [1, с. 122].

Развитие качество «ловкость» позволит спортсмену быстрее освоить новые движения, а перестроение двигательной деятельности не потребует длительного и затратного действия. В видах спорта, где постоянно меняются 
ситуации и условия исполнения элементов, это специфическое качество требует развития. Гимнастические виды предъявляют к развитию ловкости свои специфические требования: скорость принятия поз при выполнении сложнокоординационных упражнений, ориентация в пространстве при выполнении безопорных элементов и т.д.

Если говорить точно, то в спортивных видах гимнастики используется термин «координационные способности», так как основными элементами соревновательных программ являются движения с сложнокоординационными перемещениями. И поэтому в исследованиях спортивной гимнастики основным объектом выступают именно координационные способности [2, с. 153].

В физической культуре и спорте существуют определенные методы и средства развития координационных способностей. Также присутствует ряд факторов влияющих на развитие координационных способностей, являющихся основными при развитии этих способностей, при этом необходимо учитывать степень развития занимающегося, рост его спортивного мастерства и проводить постоянный контроль процесса развития изучаемых показателей [3, с. 267].

Для оценки любого физического качества необходимо определить комплекс тестов, характеризующий развитие изучаемых показателей, а также необходимо разработать систему оценок, которую можно использовать. Основные требования, предъявляемые к тестам (рис. 1).

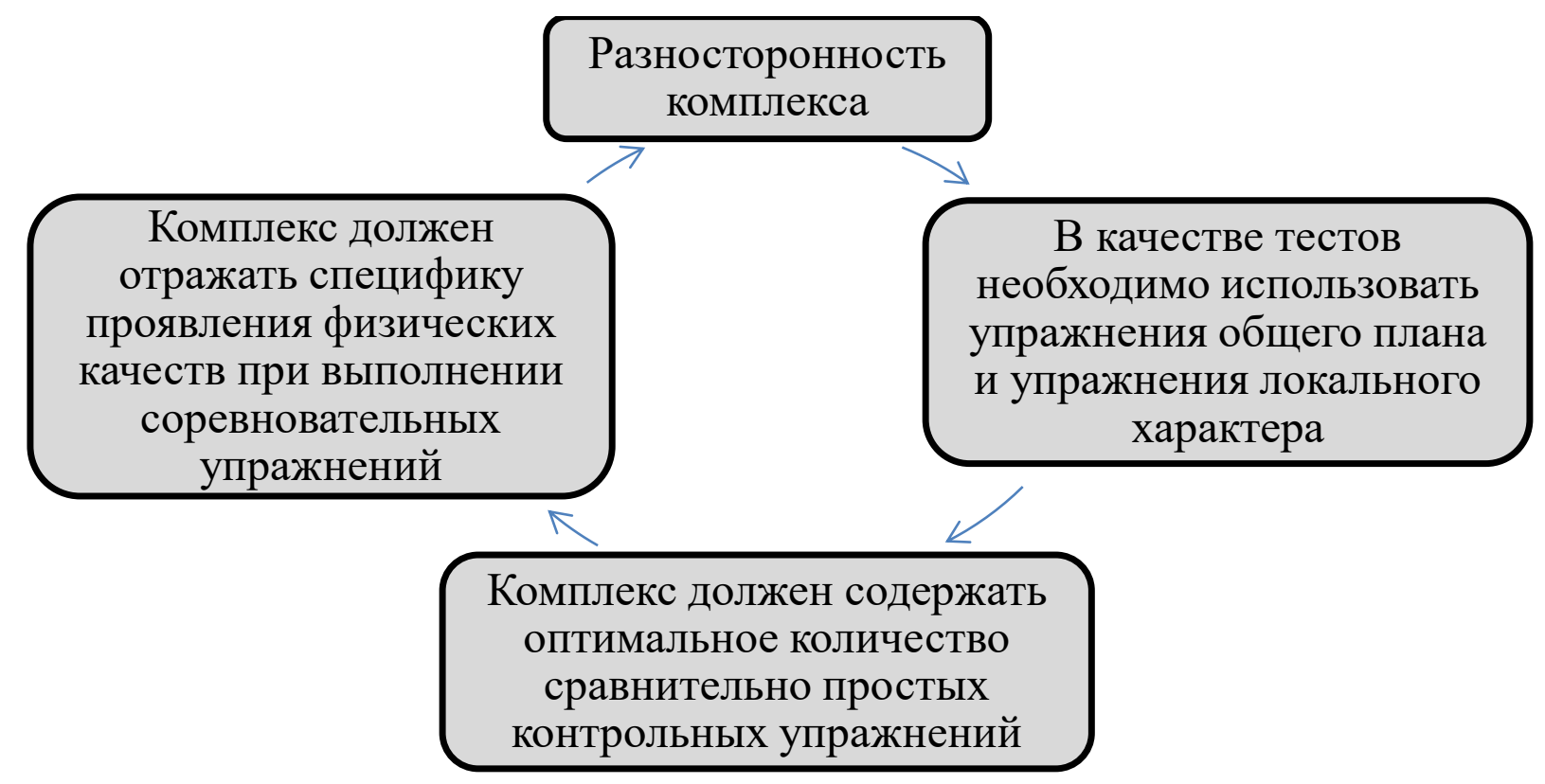

Рис. 1. - Требования, предъявляемые к подбору тестов 
Анализируя федеральный стандарт спортивной подготовки по виду спорта «спортивная гимнастика» (2017) мы определили влияние физических качеств на результативность в соревнованиях по спортивной гимнастике (рис. 2).

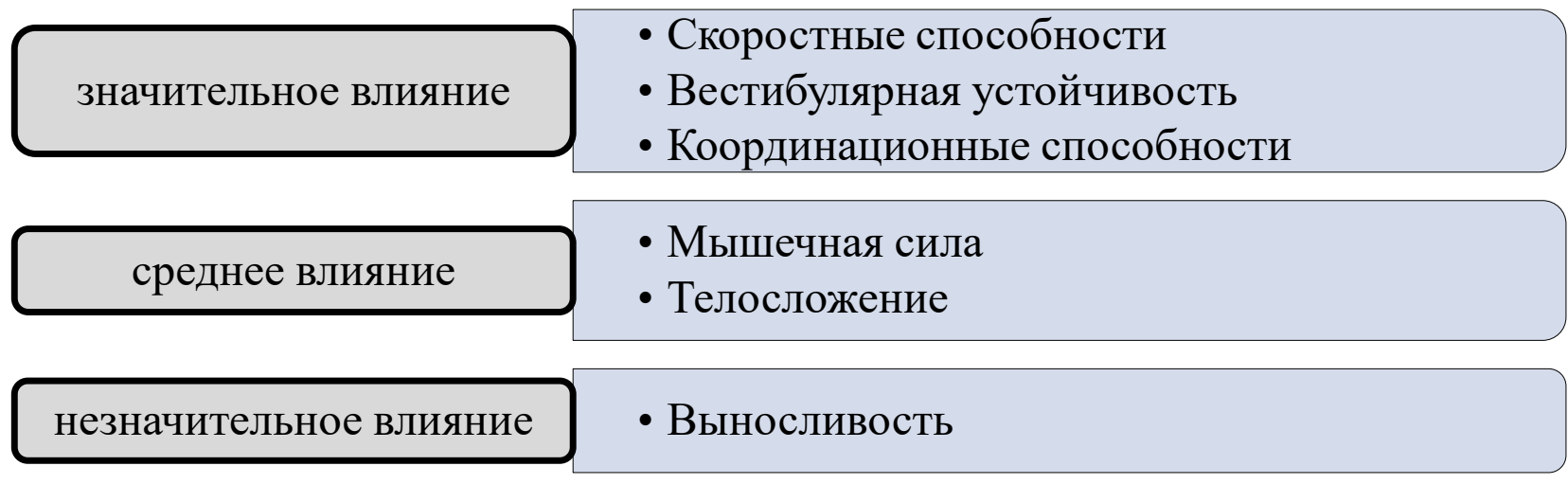

\section{Рис. 2. - Влияние физических качеств и телосложения на результативность в спортивной гимнастике}

Исходя из вышеизложенных фактов, мы смогли провести педагогическое наблюдение за спортсменками, занимающихся спортивной гимнастикой на этапе начальной подготовки.

\section{2 Определение критериев оценки координационных способностей}

\section{гимнасток на начальном этапе подготовки}

Педагогическое наблюдение, проводимое на тренировочных занятиях ГБУ Краснодарского края «Центр олимпийской подготовки им. Г.К. Казаджиева» в отделении спортивной гимнастики, позволило нам на практике увидеть организацию тренировочных занятий, в которых отдельные его части были направлены на развитие координационных способностей юных гимнасток. В ходе наблюдения обозначились основные средства и методы, используемые тренерами в процессе целенаправленной подготовки по развитию координации движений юных гимнасток. Отмечалась быстрота освоения движений, точность его выполнения, степень уверенности. Данные педагогических наблюдений использовались для выбора контрольных тестовых заданий $[4$, с. 167,5, с. 73$]$. 
Выбор контрольных испытаний осуществляется на основе данных научно-методической литературы и передового опыта тренеров, ведущих подготовку юных гимнасток, и включал в себя изложенные ниже тесты.

1. Тест на сочетание и переключение движений, представляющий собой следующе упражнение:

И.П. - О.С.

1 - прыжком стойка ноги врозь

2 - прыжком И.П.

3 - прыжком стойка ноги врозь

4 - прыжком И.П.

5 - прыжком стойка ноги врозь, руки в стороны

6 - прыжком И.П.

7 - прыжком стойка ноги врозь, руки вперед

8 - прыжком И.П.

Упражнение необходимо выполнить без остановки и повторить сначала. После показа упражнения спортсмену предоставлялась одна-две пробных попытки, а затем - зачетная. Если исполнитель выполнял упражнение с первой попытки без остановок и ошибок, то оно оценивалось из 10 баллов, со второй из 9 баллов.

При неточных положениях рук, и незначительных нарушениях ритма движений производилась сбавка от 0,2 до 0,5 балла. За кратковременную остановку $-1,0$ балл.

2. Тест на воспроизведение 50\% от максимально возможного результата в прыжках в длину (ошибка в сантиметрах). Предварительно определялся максимальный результат прыжка в длину. Затем рассчитывался и отмечался уровень, равный 50\% от максимального. Спортсменам предоставлялось несколько пробных и 3 зачетных попытки, в которых необходимо было выполнить этот результат.

3. Тест на точность движений в безопорном положении. Прыжок вверх с поворотом на $360^{\circ}$ (ошибка в градусах). Гимнастке предоставлялось несколько пробных попыток, которые выполнялись в центре градуированного круга. В зачетной попытке к ногам крепилась стрелка гониометра, с помощью которой определялось отклонение от заданного угла поворота. Ступни сомкнуты, приземление фиксировалось в течение 3 с.

4. Тест на точность движений в безопорном положении. Прыжок вверх с поворотом на $180^{\circ}$ (ошибка в градусах). Гимнастке предоставлялось несколько 
пробных попыток, которые выполнялись со зрительным контролем в центре градуированного круга. В зачетной попытке (без зрительного контроля) к ногам крепилась стрелка гониометра, с помощью которой определялось отклонение от заданного угла поворота. Ступни сомкнуты, приземление необходимо было фиксировать в течение трех секунд.

5. Тест на вестибулярную устойчивость. Повороты на месте и ходьба по прямой линии 5 м (отклонение в см). Гимнастка переступанием выполняет 5 поворотов на $360^{\circ}$ и проходила в быстром темпе 5 м по линии на гимнастическом ковре. Точность передвижения определялась по максимальному отклонению в любую сторону от осевой линии.

6. Тест на вестибулярную устойчивость. Круговые движения головой (c). Из основной стойки по команде гимнастка закрывал глаза и начинал круговые движения головой (одно движение в секунду). Окончанием упражнения считалась потеря равновесия или нарушения положения.

7. Тест на сохранение равновесия в условиях ограниченной опоры. Сомкнутая стойка на носках на низком бревне (c). По команде спортсменка принимает положение сомкнутой стойки на носках продольно на снаряде, руки вверх. Окончанием упражнения считалась потеря равновесия или падение с бревна.

8. Тест на сохранение равновесия в условиях ограниченной опоры. Балансирование на среднем бревне (c). Гимнастка выполняла упражнение на среднем бревне, руки в стороны, на любой ноге, другая - вниз - в сторону. По команде спортсмена принимала заданное положение. Окончанием считалась потеря равновесия или падение. Засчитывалась лучшая попытка из трех.

Так как в спортивной гимнастике уровень развитости координационных способностей непосредственно влияет на успешность соревновательного выступления, нами для определения уровня технической подготовленности, было проведено педагогическое наблюдение соревновательного мероприятия «Первенстве города», в котором участвовали наши испытуемые и выполняли классификационную программу по 2 спортивному юношескому разряду [6, с. 187, 7, с. 53]. Ими выполнялись упражнения на всех четырех снарядах гимнастического многоборья. Максимальная оценка на каждом снаряде составляла 10 баллов.

1-е упражнение. Опорный прыжок. Упражнение выполняется на горку гимнастических матов ( $\mathrm{h}=80 \mathrm{~cm})$ (табл. 1$)$. 
Таблица 1

Классификационное упражнение - опорный прыжок

\begin{tabular}{|c|c|c|c|c|}
\hline $\begin{array}{l}\text { № } \\
\Pi / \Pi\end{array}$ & Содержание & $\begin{array}{c}\text { Методические } \\
\text { указания }\end{array}$ & $\begin{array}{c}\text { Специфические сбавки, } \\
\text { не предусмотренные } \\
\text { правилами соревнований }\end{array}$ & $\begin{array}{c}\text { Стоимость } \\
\text { элемента } \\
\text { (балл) }\end{array}$ \\
\hline 1 & $\begin{array}{l}\text { С разбега } \\
\text { наскок на } \\
\text { мостик, } \\
\text { прыжок в } \\
\text { стойку на } \\
\text { руках, падение } \\
\text { на спину }\end{array}$ & $\begin{array}{l}\text { Прыжок в стойку и } \\
\text { падение на спину } \\
\text { выполнять прямым } \\
\text { телом. }\end{array}$ & $\begin{array}{l}\text { Сгибание в тазобедренных } \\
\text { суставах: } \\
\text { до } 15^{0}-0,1 \\
\text { от } 15^{0}-45^{0}-0,3 \\
\text { от } 45^{0}-90^{0}-0,5 \\
\text { более } 90^{0}-1,0 \\
\text { Прогибание туловища -0,1- } \\
0,3\end{array}$ & 10,0 \\
\hline
\end{tabular}

2-е упражнение. Брусья разной высоты. Упражнение выполняется на нижней жерди в строгой последовательности, описанной в табл. 2 из И.П. стоя лицом к нижней жерди.

Таблица 2

Классификационное упражнение на брусьях разной высоты

\begin{tabular}{|c|c|c|c|c|}
\hline $\begin{array}{l}\text { № } \\
\Pi / \Pi\end{array}$ & Содержание & $\begin{array}{c}\text { Методические } \\
\text { указания }\end{array}$ & $\begin{array}{c}\text { Специфические сбавки, } \\
\text { не предусмотренные } \\
\text { правилами соревнований }\end{array}$ & $\begin{array}{c}\text { Стоимость } \\
\text { элемента } \\
\text { (балл) }\end{array}$ \\
\hline 1 & $\begin{array}{l}\text { С прыжка подъём } \\
\text { переворотом в } \\
\text { упор }(\mathrm{O})\end{array}$ & Упор обозначить & & 2,0 \\
\hline 2 & Отмах - отмах & $\begin{array}{l}\text { Выполнять ноги } \\
\text { вместе на уровне } \\
\text { горизонтали и выше. } \\
\text { В конце отмаха } \\
\text { туловище - прямая } \\
\text { линия. }\end{array}$ & $\begin{array}{l}\text { Ниже горизонтали }-0,3 \\
\text { Отмах ноги врозь } \\
\text { (разведение ног) } \\
\text { до } 15^{0}-0,1 \\
\text { более } 15^{0}-0,3\end{array}$ & $1,5+1,5$ \\
\hline 3 & $\begin{array}{l}\text { Оборот назад } \\
\text { через упор }\end{array}$ & Тело прямое & $\begin{array}{l}\text { Сгибание туловища } \\
\text { до } 15^{0}-0,1 \\
15^{0}-45^{0}-0,3 \\
\text { больше } 45^{0}-0,5\end{array}$ & 3,0 \\
\hline 4 & $\begin{array}{l}\text { Вторым оборотом } \\
\text { соскок дугой }\end{array}$ & $\begin{array}{l}\text { Выполнять без паузы } \\
\text { в упоре прямым } \\
\text { телом. Таз на уровне } \\
\text { или выше жерди. }\end{array}$ & $\begin{array}{l}\text { При выполнении соскока } \\
\text { дугой таз ниже горизонтали } \\
\text { - 0,3. } \\
\text { Прогнутое тело - 0,1- 0,3 - } \\
0,5 \text {. }\end{array}$ & 2,0 \\
\hline
\end{tabular}


3-е упражнение. Упражнение на бревне. Комбинация выполняется в последовательности как описано в табл. 3. Комбинацию требуется выполнять не менее 2 линий. При выполнении менее 2 линий - 0,5 балла. При выполнении комбинации разрешается выполнение дополнительных шагов и связующих элементов. Допускается использование подставки для наскока в упор. И.П. стоя в начале бревна, продольно.

Таблица 3

\section{Классификационное упражнение на бревне}

\begin{tabular}{|c|c|c|c|c|}
\hline $\begin{array}{l}\text { № } \\
\Pi / \Pi\end{array}$ & Содержание & $\begin{array}{c}\text { Методические } \\
\text { указания }\end{array}$ & $\begin{array}{c}\text { Специфические } \\
\text { сбавки, } \\
\text { не предусмотренные } \\
\text { правилами } \\
\text { соревнований }\end{array}$ & $\begin{array}{c}\text { Стоимость } \\
\text { элемента } \\
\text { (балл) }\end{array}$ \\
\hline 1. & $\begin{array}{l}\text { Наскок в упор, поднимая } \\
\text { ногу (правую или левую), } \\
\text { положить на бревно, } \\
\text { приставляя другую ногу, } \\
\text { поворот на } 90^{0} \text { в } \\
\text { положение лёжа на } \\
\text { животе, выпрямляя руки, } \\
\text { сед ноги врозь - силой угол } \\
\text { ноги врозь (О) - силой, } \\
\text { поднимая спину упор } \\
\text { присев, встать. }\end{array}$ & $\begin{array}{l}\text { Фиксация } \\
\text { положения угол } \\
\text { ноги врозь не } \\
\text { менее } 1 \text { с }\end{array}$ & $\begin{array}{l}\text { Фиксация положения } \\
\text { угол ноги врозь менее } \\
1 \text { с - 0,3. }\end{array}$ & $0,5+0,5+0,5$ \\
\hline 2. & $\begin{array}{l}\text { Приставные шаги на } \\
\text { полной стопе }\end{array}$ & $\begin{array}{l}\text { Два шага } \\
\text { левая/правая } \\
\text { спереди и два шага } \\
\text { правая/левая } \\
\text { спереди. }\end{array}$ & & 0,5 \\
\hline 3. & $\begin{array}{l}\text { Прыжки вверх со сменой } \\
\text { ног через деми-плие. }\end{array}$ & $\begin{array}{l}\text { Выполнять два } \\
\text { прыжка } \\
\text { (поочерёдно правая } \\
\text { и левая спереди). В } \\
\text { полёте ноги } \\
\text { прямые, стопы } \\
\text { оттянуты. Руки на } \\
\text { пояс. }\end{array}$ & & 1,5 \\
\hline
\end{tabular}




\begin{tabular}{|c|c|c|c|c|}
\hline 4. & Шаги на полупальцах & $\begin{array}{l}\text { Выполнять четыре } \\
\text { шага. Руки в } \\
\text { стороны. }\end{array}$ & & 0,5 \\
\hline 5. & Поворот на $180^{\circ}$ & $\begin{array}{l}\text { Выполнять на } \\
\text { прямых ногах, на } \\
\text { высоких } \\
\text { полупальцах. } \\
\text { Закончить поворот } \\
\text { на полупальцах. } \\
\text { Руки произвольно. }\end{array}$ & $\begin{array}{l}\text { Недостаточная } \\
\text { высота полупальцев - } \\
0,1 \\
\text { Поворот на полной } \\
\text { стопе - 0,5 } \\
\text { Опускание на всю } \\
\text { стопу после поворота } \\
\text { - 0,3 }\end{array}$ & 1,5 \\
\hline 6. & $\begin{array}{l}\text { Любое равновесие с } \\
\text { прямой ногой ( } 2 \text { сек.) }\end{array}$ & $\begin{array}{l}\text { Разрешается } \\
\text { выполнять боковое } \\
\text { или переднее } \\
\text { равновесие с } \\
\text { удержанием ноги } \\
\text { рукой. Нога выше } \\
\text { горизонтали. }\end{array}$ & $\begin{array}{l}\text { Нога на уровне } \\
\text { горизонтали - 0,3 } \\
\text { Нога ниже уровня } \\
\text { горизонтали - 0,5 }\end{array}$ & 1,5 \\
\hline 7. & $\begin{array}{l}\text { Приставные шаги любым } \\
\text { боком, с волной руками, } \\
\text { руки в стороны. }\end{array}$ & $\begin{array}{l}\text { Не менее двух } \\
\text { шагов }\end{array}$ & $\begin{array}{l}\text { Недостаточная волна } \\
-0,1-0,3\end{array}$ & 1,0 \\
\hline 8. & $\begin{array}{l}\text { С шага полуприсед на } \\
\text { правой левая спереди на } \\
\text { уровне горизонтали и } \\
\text { выше, выпрямляя опорную } \\
\text { ногу, шаг, полуприсед на } \\
\text { левой правая на уровне } \\
\text { горизонтали и выше. }\end{array}$ & $\begin{array}{l}\text { Сгибание опорной } \\
\text { ноги } 45^{0}-90^{0} . \\
\text { Фиксация } \\
\text { положения } \\
\text { полуприсед не } \\
\text { менее } 1 \text { сек. } \\
\text { Выполнять руки в } \\
\text { стороны. }\end{array}$ & $\begin{array}{l}\text { Сгибание опорной } \\
\text { ноги менее } 45^{0}-0,5 \\
\text { Фиксация менее } 1 \text { с- } \\
0,3\end{array}$ & 1,0 \\
\hline 9. & $\begin{array}{l}\text { Соскок. С конца бревна, } \\
\text { прыжок вверх } \\
\text { прогнувшись с махом рук } \\
\text { снизу-вверх. }\end{array}$ & & & 1,0 \\
\hline
\end{tabular}

4-е упражнение. Вольное упражнение. Составляются произвольно из представленных в табл.4 элементов. Разрешается добавление связующих элементов и движений. Допускается выполнение без музыкального сопровождения. Выполняется из И.П. - основная стойка. 
Таблица 4

Элементы для классификационного вольного упражнения

\begin{tabular}{|c|c|c|c|c|}
\hline $\begin{array}{l}\text { № } \\
\Pi / \Pi\end{array}$ & Содержание & Методические указания & $\begin{array}{c}\text { Специфические сбавки, } \\
\text { не предусмотренные } \\
\text { правилами } \\
\text { соревнований. }\end{array}$ & $\begin{array}{c}\text { Стоимость } \\
\text { элемента } \\
\text { (балл) }\end{array}$ \\
\hline 1. & $\begin{array}{l}\text { Любое равновесие } \\
\text { с прямой ногой } \\
(2 \mathrm{c}) .\end{array}$ & $\begin{array}{l}\text { Нога выше горизонтали. } \\
\text { Выполнять без захвата } \\
\text { ноги рукой. }\end{array}$ & $\begin{array}{l}\text { На уровне горизонтали } \\
-0,1 \\
\text { Ниже горизонтали - } \\
0,3\end{array}$ & 1,5 \\
\hline 2. & $\begin{array}{l}\mathrm{C} \text { шага медленный } \\
\text { переворот с } \\
\text { поворотом } \\
\text { («рондат») }\end{array}$ & $\begin{array}{l}\text { Выполнять с соединением } \\
\text { ног в стойке на руках, с } \\
\text { последующим } \\
\text { опусканием ноги вместе. }\end{array}$ & $\begin{array}{l}\text { Отклонение от } \\
\text { направления движения } \\
-0,1-0,3-0,5\end{array}$ & 1,5 \\
\hline 3. & $\begin{array}{l}\text { Кувырок назад с } \\
\text { прямыми ногами и } \\
\text { руками в упор, стоя } \\
\text { согнувшись. }\end{array}$ & & & 1,5 \\
\hline 4. & $\begin{array}{l}\text { Медленный } \\
\text { переворот назад с } \\
\text { одной ноги, встать } \\
\text { по одной. }\end{array}$ & & & 1,5 \\
\hline 5. & $\begin{array}{l}\text { С шага через } \\
\text { стойку на руках - } \\
\text { перекат вперёд } \\
\text { согнувшись с } \\
\text { прямыми руками и } \\
\text { ногами, встать } \\
\text { руки вверх. }\end{array}$ & $\begin{array}{l}\text { Допускается выполнение } \\
\text { как с удержанием стойки } \\
\text { на руках, так и } \\
\text { проходящим движением } \\
\text { через стойку на руках. }\end{array}$ & $\begin{array}{l}\text { Сгибание в } \\
\text { тазобедренных } \\
\text { суставах в стойке на } \\
\text { руках: } \\
\text { до } 15^{0}-0,1 \\
\text { от } 15^{0} \text { до- } 0,3\end{array}$ & $1,0+1,0$ \\
\hline 6 & $\begin{array}{l}\text { Упор присев } \\
\text { «шпагат» любой (2 } \\
\text { сек.), встать } \\
\text { произвольно. }\end{array}$ & & & 1,0 \\
\hline 7. & $\begin{array}{l}\text { Шаги галопом, } \\
\text { наскок на две - } \\
\text { прыжок с } \\
\text { поворотом на } 180 \text { в } \\
\text { доскок. }\end{array}$ & $\begin{array}{l}\text { Галоп выполнять не } \\
\text { менее двух шагов подряд } \\
\text { с каждой ноги. }\end{array}$ & & 1,0 \\
\hline
\end{tabular}


Результаты педагогического наблюдения позволили нам собрать достаточное количество информационного материала, необходимого для определения основных критериев оценки координационных способностей гимнасток, занимающихся на этапе начальной подготовки.

\section{3 Информативность тестов координационных способностей гимнасток на начальном этапе подготовки}

На основании результатов педагогического наблюдения, а именно методика проведения тестов определяющих развитость координационных способностей и результатов соревнований юных гимнасток, мы смогли произвести необходимые математические расчеты, необходимые для определения информативности подобранных критериев оценки координационных способностей спортсменок [8, с. 103]. Основным критерием информативности изучаемых показателей является их достоверная взаимосвязь с суммой баллов за выполнение соревновательных упражнений (табл. 5).

Таблица 5

Информативность тестов координационных способностей гимнасток на

начальном этапе подготовки $(\mathbf{n = 2 3})$

\begin{tabular}{|l|c|c|c|c|}
\hline \multicolumn{1}{|c|}{ Название теста } & $\mathbf{M} \pm \mathbf{m}$ & $\boldsymbol{\sigma}$ & $\mathbf{r}$ & \multicolumn{1}{|c|}{$\mathbf{P}$} \\
\hline 1. Тест на сочетание и переключение движений (балл) & $8,7 \pm 0,17$ & 0,8 & 0,44 & $\leq 0,05$ \\
\hline $\begin{array}{l}\text { 2. Тест на воспроизведение 50\% от максимально } \\
\text { возможного результата в прыжках в длину (ошибка в } \\
\text { сантиметрах) }\end{array}$ & $6,2 \pm 0,25$ & 1,2 & 0,36 & $>0,05$ \\
\hline $\begin{array}{l}\text { 3. Тест на точность движений в безопорном положении. } \\
\text { Прыжок вверх с поворотом на 360 (ошибка в градусах) }\end{array}$ & $7,0 \pm 0,19$ & 0,9 & 0,49 & $\leq 0,05$ \\
\hline $\begin{array}{l}\text { 4. Тест на точность движений в безопорном положении. } \\
\text { Прыжок вверх с поворотом на 180 (ошибка в градусах) }\end{array}$ & $4,3 \pm 0,15$ & 0,7 & 0,42 & $\underline{\leq 0,05}$ \\
\hline $\begin{array}{l}\text { 5. Тест на вестибулярную устойчивость. Повороты на } \\
\text { месте и ходьба по прямой линии 5 м (отклонение в см) }\end{array}$ & $3,6 \pm 0,13$ & 0,6 & 0,46 & $\underline{\leq 0,05}$ \\
\hline $\begin{array}{l}\text { 6. Тест на вестибулярную устойчивость. Круговые } \\
\text { движения головой (с) }\end{array}$ & $9,4 \pm 0,23$ & 1,1 & 0,24 & $>0,05$ \\
\hline $\begin{array}{l}\text { 7. Тест на сохранение равновесия. Сомкнутая стойка на } \\
\text { носках на низком бревне (с) }\end{array}$ & $10,5 \pm 0,27$ & 1,3 & 0,47 & $\leq 0,05$ \\
\hline $\begin{array}{l}\text { 8. Тест на сохранение равновесия. Балансирование на } \\
\text { среднем бревне (с) }\end{array}$ & $7,8 \pm 0,25$ & 1,2 & 0,43 & $\underline{\leq 0,05}$ \\
\hline
\end{tabular}


Корреляционный анализ тестов, определяющих уровень развития координационных способностей гимнасток показал среднюю степень взаимосвязи с соревновательным результатом $(\mathrm{P}<0,05)$ в следующих тестах:

- «Тест на сочетание и переключение движений (балл)» - r = 0,44;

- «Прыжок вверх с поворотом на $360^{\circ}$ (ошибка в градусах)» - r = 0,49;

- «Прыжок вверх с поворотом на $180^{\circ}$ (ошибка в градусах)» - r = 0,42;

- «Повороты на месте и ходьба по прямой линии 5 м (отклонение в см)» $\mathrm{r}=0,46$;

- «Сомкнутая стойка на носках на низком бревне (c)» - r = 0,47;

- «Балансирование на среднем бревне (c)» - r =0,43.

Остальные тесты не проявили взаимосвязи с соревновательным результатом, то есть неинформативны и в дальнейшем исследовании не использовались. Следовательно, результаты предварительно проведенных исследований и расчетов позволили из первично определенных 8 тестов отобрать в комплекс для оценки координационной подготовленности, следующие 6 контрольных упражнений (рис. 3).

оценка умения сочетать и переключать движения

оценка умения оценивать свои движения в пространстве

оценка способности сохранять равновесие в различных условиях

оценка умения оценивать временные интервалы
- Тест на сочетание и переключение движений

- Повороты на месте и ходьба по прямой линии 5 м

- Сомкнутая стойка на носках на маленьком бревне

- Балансирование на среднем бревне

- Прыжок вверх с поворотом на $360^{\circ}$

- Прыжок вверх с поворотом на $180^{\circ}$

\section{Рис. 3. - Комплекс для оценки координационных способностей гимнасток} на начальном этапе подготовки

Таким образом, основываясь на теории изучения координационных способностей и полученных результатах исследования, мы можем сгруппировать тесты оценки координационных способностей в 4 основные группы, характеризующих сами координационные способности как: 
- умение/способность сочетать и переключать свои действия;

- умение/способность оценивать свои движения в пространстве;

- умение/способность сохранять равновесие в различных условиях;

- умение/способность оценивать и контролировать временные интервалы.

\section{4 Разработка оценочных шкал результатов тестирования} координационной подготовленности гимнасток

начального этапа подготовки

Так как результаты контрольных упражнений были выражены в разных единицах измерения (секунды, баллы, количество повторений), возникла необходимость в разработке шкал относительной оценки результатов тестирования координационной подготовленности (таблица 6).

Таблица 6

Шкалы относительной оценки координационной подготовленности Гимнасток

\begin{tabular}{|c|c|c|c|c|c|c|c|c|c|c|c|}
\hline \multicolumn{2}{|c|}{ 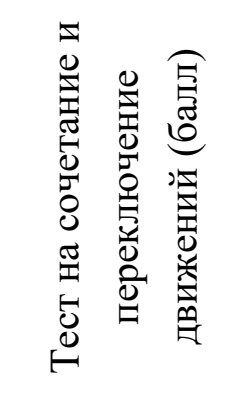 } & \multicolumn{2}{|c|}{ 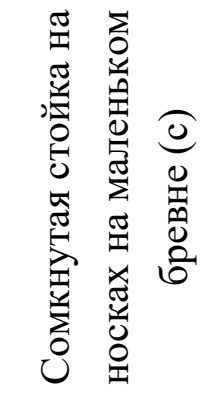 } & \multicolumn{2}{|c|}{ 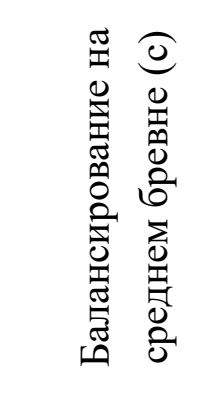 } & 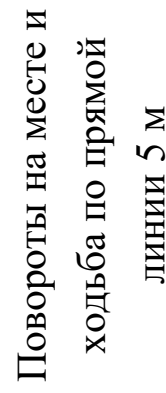 & 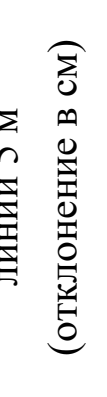 & \multicolumn{2}{|c|}{ 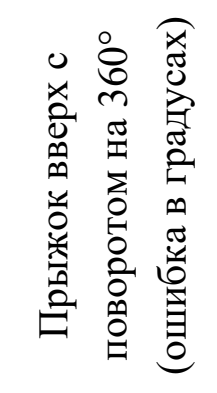 } & \multicolumn{2}{|c|}{ 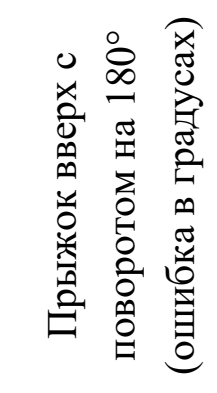 } \\
\hline 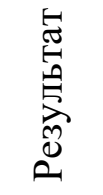 & $\begin{array}{l}5 \\
\text { క్రీ }\end{array}$ & 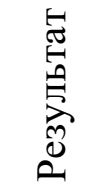 & 点 & 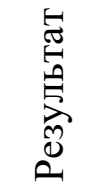 & 点 & 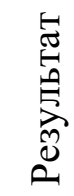 & క్ & 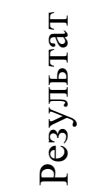 & క్ & 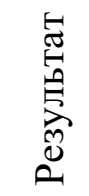 & $\begin{array}{l}5 \\
\text { క్రీ }\end{array}$ \\
\hline 11,0 & 10,0 & 14,8 & 10,0 & 12,0 & 10,0 & 5,0 & 10,0 & 12,0 & 10,0 & 10,0 & 10,0 \\
\hline 10,0 & 9,0 & 13,8 & 9,0 & 11,0 & 9,0 & 4,5 & 9,0 & 10,7 & 9,0 & 8,8 & 9,0 \\
\hline 9,0 & 8,0 & 12,8 & 8,0 & 10,0 & 8,0 & 4,0 & 8,0 & 9,4 & 8,0 & 7,6 & 8,0 \\
\hline 8,0 & 7,0 & 11,8 & 7,0 & 9,0 & 6,0 & 3,5 & 6,0 & 8,1 & 6,0 & 6,4 & 6,0 \\
\hline 7,0 & 6,0 & 10,8 & 6,0 & 8,0 & 5,0 & 3,0 & 5,0 & 6,8 & 5,0 & 5,2 & 5,0 \\
\hline 6,0 & 5,0 & 9,8 & 5,0 & 7,0 & 4,0 & 2,5 & 4,0 & 5,5 & 4,0 & 4,0 & 4,0 \\
\hline 5,0 & 4,0 & 8,8 & 4,0 & 6,0 & 3,0 & 2,0 & 3,0 & 4,2 & 3,0 & 2,8 & 3,0 \\
\hline 4,0 & 3,0 & 7,8 & 3,0 & 5,0 & 2,0 & 1,5 & 2,0 & 2,9 & 2,0 & 1,6 & 2,0 \\
\hline 3,0 & 2,0 & 6,8 & 2,0 & 4,0 & 1,0 & 1,0 & 1,0 & 1,6 & 1,0 & 0,4 & 1,0 \\
\hline 2,0 & 1,0 & 5,8 & 1,0 & 3,0 & 0 & 0,5 & 0 & 0,3 & 0 & 0 & 0 \\
\hline 1,0 & 0 & 4,8 & 0 & & & & & & & & \\
\hline 1,0 & 1,0 & 1,0 & 1,0 & 1,0 & 1,0 & 0,5 & 1,0 & 1,3 & 1,0 & 1,2 & 1,0 \\
\hline
\end{tabular}


Таким образом, для текущего и этапного контроля координационной подготовленности гимнасток начального этапа подготовки необходимо применять разработанные шкалы относительной оценки результатов тестирования.

\section{Список литературы}

1. Аркаев Л.Я. Как готовить чемпионов / Л.Я. Аркаев, Н.Г. Сучилин. Москва: Ф и С, 2004. - 328 с.

2. Барчуков И.С. Физическая культура и спорт. Методология, теория, практика / И.С. Барчуков, А.А. Нестеров. - М.: «Академия», 2009. - 528 с.

3. Фискалов В.Д. Спорт и система подготовки спортсменов: учебник / В.Д. Фискалов. - М.: Советский спорт, 2010. - 392 с.

4. Иссурин В.Б. Координационные способности спортсменов / В.Б. Иссурин, В.И. Лях; пер. с англ. И.В. Шаробайко. - М.: Спорт, 2019. - 208 с.

5. Ботяев В.Л. Взаимосвязь координационных способностей с показателями технического мастерства в гимнастике на различных этапах спортивной тренировки (на примере спортивной и художественной гимнастики) /В.Л. Ботяев // Теория и практика физ.культуры тренер: журнал в журнале. - 2011. - №11. - С. 71-75.

6. Современная гимнастика: проблемы, тенденции, перспективы: сборник материалов VI Международной научно-практической конференции / Российский гос. пед. ун-т им. А.М. Герцена; под общ. ред. А.Н. Дитянина. Санкт-Петербург: Изд-во РГПУ, 2011. - 230с.

7. Бажаев А.З. Развитие силовых возможностей человека как базовая для реализации координационных способностей / А.З. Бажаев, В.П. Лукьяненко, А.А. Хенев. // Теория и практика физической культуры. - 2007. - №6. - С. 52-54.

8. Чопорова Е.В. Теория и методика избранного вида спорта. Спортивная гимнастика. Ч. 4 [Электронный ресурс]. - Волгоград: ВГАФК, 2010. $-214 \mathrm{c}$. 
УДК 378.147

\title{
МЕТОДИЧЕСКОЕ ОБЕСПЕЧЕНИЕ РЕАЛИЗАЦИИ МОДЕЛИ ПРОФИЛЬНОЙ ПОДГОТОВКИ ПЕДАГОГА-ДЕФЕКТОЛОГА К РАБОТЕ С ДЕТЬМИ С ЗАДЕРЖКОЙ ПСИХИЧЕСКОГО РАЗВИТИЯ
}

\begin{abstract}
Лапп Елена Александровна к.п.н., доцент, доцент кафедры специальной педагогики и психологии Федеральное государственное бюджетное образовательное учреждение высшего образования «Волгоградский государственный социально-педагогический университет»
\end{abstract}

\begin{abstract}
Аннотация. Описаны результаты авторского исследования по методическому обеспечению реализации модели профильной подготовки педагогов-дефектологов к работе с детьми с задержкой психического развития в пространстве университетского образования. Кратко раскрывается характеристика уровней сформированности профильной компетентности педагога детей с ЗПР. Представлен авторский взгляд на поэтапное формирование профильной компетентности дефектолога, способного к работе с детьми с задержкой психического развития. Внедрение модели уровневого профессионального образования дефектологов обеспечивает профессиональноличностное развитие специалистов, расширение их возможностей в условиях смены сфер профессиональной деятельности.
\end{abstract}

Ключевые слова. Профильная компетентность, педагог детей с задержкой психического развития, педагогические ситуации, магистратура.

\section{METHODOLOGICAL SUPPORT FOR THE IMPLEMENTATION OF THE MODEL OF SPECIALIZED TRAINING OF A TEACHER- DEFECTOLOGIST TO WORK WITH CHILDREN WITH IMPAIRED MENTAL FUNCTION}

\section{Lapp Elena Aleksandrovna}

Abstract: The article describes the results of the author's research on methodological support for the implementation of the model of specialized training of 
teachers-defectologists to work with children with mental retardation in the space of University education. The article briefly describes the characteristics of the levels of formation of the profile competence of a teacher of children with PO. The author's view on the gradual formation of the profile competence of a defectologist capable of working with children with mental retardation is presented. Introduction of the model of level professional education of defectologists provides professional and personal development of specialists, expansion of their capabilities in the conditions of changing spheres of professional activity.

Key words. Core competence, teacher of children with impaired mental function, the teaching situation, the master's degree.

Проектирование профильной компетентности педагога-дефектолога для работы с детьми с задержкой психического ЗПР выступает в единстве целей, содержания и технологий профессиональной подготовки в системе университетского образования. Эта работа осуществляется поэтапно. Каждый из этапов характеризуется конкретными ситуациями профессионального развития и определенными уровнями сформированности профессиональных компетенций.

Каждый из компонентов профильной компетентности - мотивационноценностный, содержательно-процессуальный, рефлексивно-аналитический, профессионально-личностный - может находиться на разных уровнях сформированности, вследствие чего профильная компетентность педагога детей с ЗПР предстает как многоуровневое образование.

Нами выделены три уровня сформированности профильной компетентности педагога детей с ЗПР, а именно исполнительский, инициативный, реформаторский (преобразовательный). Каждый уровень в совокупности показателей позволяет судить о профессионализации будущего специалиста. Характеристики каждого уровня обязательно включают показатели профессионально-личностной и мотивационно-ценностной готовности педагога-дефектолога к работе с детьми с ЗПР.

Опишем характеристики каждого уровня.

- Базовый уровень (исполнительский): будущий педагог-дефектолог не осознает социальную значимость профессии и свою роль как организатора коррекционно-развивающей работы с детьми с ЗПР; имеет слабую мотивацию к будущей профессиональной деятельности с детьми с ЗПР, профессиональные мотивы не дифференцированы из многообразия личностных мотивов. Цели и 
задачи собственной профессиональной подготовки в вузе определяются в общем виде. Отношение к коррекционно-развивающей работе с детьми с ЗПР, общим и специальным психолого-педагогическим знаниям индифферентно, отсутствует система этих знаний и готовность их использовать. Отсутствуют умение формировать научную картину психолого-педагогической действительности, владение и реализация в деятельности различных видов мышления, способность к использованию специальных знаний для решения профессиональных задач. Уровень профессиональной подготовки в вузе характеризуется относительно успешным воспроизводством собственного предшествующего опыта. Студент участвует в учебно-профессиональной и учебно-научной деятельности, проявляет интерес к профессиональным проблемам, ответственно относится к педагогическим действиям, но не уверен, боится реализовать их самостоятельно, испытывает трудности при корректировке. Слабо ориентируется в ситуациях свободного выбора. Отсутствует установка на собственное моделирование структуры будущей профессиональной деятельности и ориентация на социальнопрофессиональную мобильность, а также установка на преобразование психолого-педагогических теорий в метод познавательной деятельности.

Промежуточный уровень (инициативный): отличается проявлением мотивов к будущей профессиональной деятельности. Профессиональные мотивы дифференцируются из многообразия личностных мотивов и становятся движущей силой профессиональной подготовки к работе с детьми с ЗПР в вузе. Осознаются основные проблемы предметной области, признается роль системы специальных психолого-педагогических знаний в совершенствовании психолого-педагогической действительности. Проявляется стремление к проектированию и осуществлению коррекционно-развивающей работы и использованию специальных психолого-педагогических знаний в будущей профессиональной деятельности. Имеет место осмысление теоретических идей. Формируется научная картина психолого-педагогической действительности в аспекте специального образования. Формируется положительная установка на самостоятельное моделирование структуры профильной деятельности, а также на освоение специальной дефектологической информации в качестве средств обогащения будущей профессиональной деятельности. Проявляется активное участие в учебно-профессиональной, учебно-научной и научноисследовательской деятельности, реализуется способность вносить элементы новизны в предложенный план действий, корректировать педагогические 
действия на основе результатов психолого-педагогической диагностики; осознаются творческие возможности с последующей их реализацией; проектируются методы и приемы коррекционно-развивающей работы; отмечается инициативность в коррекционно-педагогическом процессе.

Профессиональный уровень (реформаторский): характеризуется осознанностью и устойчивостью мотивов будущей профессиональной деятельности, готовностью в будущем использовать концептуальные знания при решении профессиональных задач, наличием собственных стратегий решения коррекционно-развивающих задач. Сформирована установка на моделирование профильной деятельности. Проявляется способность к проектированию проблемного поля в предметной области и решению профессиональных задач. Различные виды мышления реализуются на деятельностном уровне. Активно проявляется способность к демонстрации знаний фундаментальных и прикладных дисциплин образовательной программы, которая занимает важное место в структуре профессионального мышления. Проявляется готовность действовать в нестандартных ситуациях. Через овладение коррекционно-развивающими технологиями формируется индивидуальный стиль деятельности. Может, опираясь на знания и умения, разработать и реализовать новый способ, вариант решения педагогической ситуации. Достигается способность проектировать и реализовывать коррекционно-педагогический процесс с детьми с ЗПР. Создается свое поле профессиональной деятельности, что обогащает личностный рост обучающегося по направлению «Специальное (дефектологическое) образование», способствует самоанализу, самооценке, самопознанию, саморегуляции.

Критериальные характеристики и уровни позволяют оптимизировать процесс профильной подготовки педагога для работы с детьми с ЗПР.

Каждый этап процесса профессионального становления будущего педагога-дефектолога для работы с детьми с ЗПР характеризуется последовательным усложнением содержания профессионального образования, обусловленного поставленными целями и задачами. Соответственно формы и методы профессиональной подготовки (собственно учебный процесс, практика, учебно-научная, научно-исследовательская работа, общественная деятельность и др.) направлены на достижение студентом реформаторского уровня сформированности его профессиональной компетентности. 
В целях методического обеспечения профильной подготовки дефектологов к работе с детьми с ЗПР в вузе были выбраны:

- средства: учебные пособия «Обучение в классах КРО» и Подготовка специалистов к работе с детьми с ЗПР в условиях современных ФГОС», «Дневник практики в специальных (коррекционных) классах VII вида», методические указания, электронное учебное пособие и сайт учебного курса (sdm.vspu.ru) «Подготовка специалистов к работе с детьми с ЗПР в условиях современных ФГОС», проблемные вопросы и задания, педагогические ситуации, профессиональные задачи, педагогические проекты;

- методы: проблемная лекция, моделирование педагогических ситуаций, кейс-метод, педагогическое исследование, деловая и ролевая игра, педагогическое эссе, диалог в режиме онлайн и оффлайн и др.

- формы: дискуссии, беседы, конкурсы, конференции, ролевые игры, «квазипрофессиональная» педагогическая деятельность, коррекционнопедагогическая практика, практика по получению профессиональных умений и опыта профессиональной деятельности (диагностико-консультативная и профилактическая практика); преддипломная практика, научноисследовательская практика, научно-исследовательская работа, самостоятельная работа по освоению курсов «Обучение в классах КРО» и «Подготовка специалистов к работе с детьми с ЗПР в условиях современных ФГОС» с использованием электронных образовательных ресурсов, участие в деятельности общественных организаций, в том числе профильной направленности «Поддержка профессиональнного становления педагоговдефектологов» и др. [1].

Профессионально-уровневая подготовка будущих дефектологов к работе с детьми с ЗПР предполагает применение не только традиционных методов обучения, но и специфических, к которым в нашем исследовании мы отнесли педагогические ситуации. Педагогическая ситуация рассматривается нами как ключевое условие формирования профильных компетенций будущего педагогадефектолога для работы с детьми с ЗПР; как социально-педагогическая среда, создающая межличностные, межгрупповые, квазипрофессиональные и др. отношения и иерархию обучающихся в образовательном процессе; актуализирующая потребности, мотивы, интересы личности, которая проявляет себя лишь в определенных условиях.

Проектируемые нами ситуации мы определили как социальнопедагогические, исходя из того, что в процессе формирования профильных 
компетенций будущего педагога-дефектолога для работы с детьми с ЗПР необходимо не только целенаправленно создавать образовательную среду, планировать ситуации, но и педагогически использовать весь спектр специальных условий, в которых осуществляется профессиональная подготовка педагога-дефектолога. Все педагогические ситуации реализуются в условиях учебной, учебно-научной, научно-исследовательской, общественной деятельности студента - будущего дефектолога.

На первом этапе профессиональной подготовки в вузе в процессе использования творческо-познавательных ситуаций закладывались основы профессиональных знаний, умений и навыков, способствующих формированию опыта будущей деятельности педагога-дефектолога для работы с детьми с ЗПР и обеспечивающих формирование дефектологической компетентности в коррекционно-педагогической деятельности. Данные педагогические ситуации призваны были последовательно решать три задачи:

- создавать положительно-эмоциональное, заинтересованное отношение в будущей профессиональной деятельности, формировать понимание студентами-будущими дефектологами личностной значимости познавательного процесса;

- организовать систематическую самостоятельную деятельность творчески-поискового характера с решением проблемных задач и познавательных ситуаций, создавать условия для самостоятельной практической работы обучающихся;

- содействовать формированию новых познавательных потребностей студентов-будущих дефектологов, создавать предпосылки для становления их профессиональных интересов на основе интенсивной самостоятельной познавательной деятельности, сочетающейся с посильным участием в преобразовании педагогической действительности.

На первом этапе студент усваивает или закрепляет уже имеющиеся знания и умения, способствующие формированию опыта специфической профессиональной деятельности дефектолога; социально-педагогические ситуации обеспечивают условия для сравнения наличного и нового опыта обучающихся; включение студентов в творческо-познавательную деятельность, в процессе которой любое познание, формирование любого умения должно быть сопряжено с развитием у студентов способности реализовать их на творческой основе. Преподаватель осуществляет открытое руководство данным процессом, содействуя переходу студента от репродуктивных функций к 
творческим. Стимулирование и поощрение студентов к освоению нового профессионального опыта выступает ключевой стратегией ведущего преподавателя.

Творческо-познавательная ситуация трактуются нами как педагогическое условие, в котором актуализируется интеллектуальная активность обучающегося или продолжается его познавательная деятельность «за пределами заданной ситуации» [2]. Творческо-познавательные ситуации обеспечивают формирование у студентов не только познавательных, но и профессиональных мотивов и интересов; творческий характер процесса обучения; приобретение студентами опыта инновационной деятельности в контексте будущей профессии; воспитывают системное мышление специалиста, включающего ценностное понимание природы и общества, сути дефектологической профессиональной деятельности, себя, своего места в мире и в профессии; формирование целостного представления о профессии педагогадефектолога детей с ЗПР; обучение коллективной мыслительной и практической работе, формирование умений и навыков коммуникации и межличностного взаимодействия, индивидуального и совместного принятия решений; воспитание ответственного отношения к делу, усвоение групповых и индивидуальных педагогических ценностей и установок коллектива; обучение методам моделирования и педагогического проектирования.

В условиях ключевой на этом этапе учебной дисциплины «Обучение в классах коррекционно-развивающего обучения» формируются представления о сфере труда педагога, реализующего адаптированные образовательные программы для детей с ЗПР. Как показывает наш опыт, приступая к освоению данного курса, студенты, чаще всего имеют очень обобщенные представления о работе педагога-дефектолога для детей с задержкой психического развития. Работа продолжается во время практики, экскурсий в учреждения, в летней научной школе дефектологов «Ресурс» [3]. Собственная активность студентов становится основой их профессионального самосовершенствования [4]. Представляется важным, чтобы в процессе обучения студенты видели метапредметные, предметные и личностные результаты, которые достигают обучающиеся в создаваемых специальным педагогом специальных коррекционно-развивающих условиях. Это, а также знакомство с различными видами деятельности педагога-дефектолога для детей с ЗПР в общей и коррекционной практике, с обучающимися, воспитанниками разного возраста и 
степенью нарушения познавательных или социальных способностей позволяет будущим дефектологам выбрать объект профессиональной деятельности.

Во время практики проводятся экскурсии в группы и классы для детей с ЗПР, в реабилитационные центры, негосударственные образовательные учреждения. Внимание студентов обращается на разнообразие видов деятельности, которые выполняет педагог детей с ЗПР, на структурирование его рабочего времени, на профессионально-личностные качества. Организации наблюдений студентов способствуют рефлексивные задания «Вопрос-ответ» («Что нового я сегодня узнал; что до сегодняшнего дня было не очень понятно, а теперь обрело смысл; какой он, ребенок с задержанным развитием как субъект моего познания; какое место занимает ребенок с ЗПР в моих субъективных «переживаниях»?), эссе «Кто он, учитель для детей с ЗПР?», «Нужны ли специальные профессионально-личностные качества педагогу детей с ЗПР» и др.

После посещения образовательных организаций, реализующих адаптированные образовательные программы для детей с ЗПР вместе со студентами обсуждаются их впечатления. Творческо-познавательные ситуации создают условия для структурирования знаний обучающихся о детях с нарушениями в развитии в целом, и выявления специфики детей с задержкой психического развития с позиций традиционных и современных подходов. Для этого используется методический прием «Круг», когда каждый участник в порядке очередности высказывает свое мнение на вопрос преподавателя или одногруппника. Например, «Чем отличаются дети с ЗПР от детей с нарушением интеллекта?», «Можете ли оценить трудности, которые испытывают дети с задержкой психического развития в процессе усвоения материала учебных предметов?» и др.

Представления о деятельности педагога детей с ЗПР помогают актуализировать задания, связанные с изучением нормативно-правовой документации; наблюдением на обучающимися на уроках и во внеурочной деятельности; участие в работе школьного психолого-педагогического консилиума.

При изучении дисциплины «Обучение в классах КРО» студенты знакомятся с историей коррекционно-развивающего обучения. Минисочинения «Дети с задержкой психического развития: взгляд вчера и сегодня», «Обучаемость и обученность: что важнее для развития школьника?»; проекты «Современный школьник с ЗПР: кто он?», «Обучаемость как принцип оценки 
умственного развития школьников с ЗПР» направлены на обобщение представлений студентов о специфических особенностях детей с задержкой психического развития. Приемы, используемые в работе со студентами не только актуализируют интеллектуальную активность обучающихся, но и развивают познавательную деятельность в предлагаемых измененных условиях.

Создание стойкого положительного отношения к профессии педагога детей с ЗПР - задача всех этапов вузовского обучения. Еще на первом этапе важно показать значимость профессиональной подготовки к работе с детьми этой категории. Это достигается во время активного обучения в студенческой научной школе или в условиях профильного научного студенческого сообщества. Организация ролевых и деловых игр, связанных с изучением нормативной документации; решение педагогических задач выявляют противоречия между декларированием прав обучающихся и неготовностью педагогических кадров к работе с детьми с ЗПР. Беседы с педагогамипрактиками убеждают молодых людей в необходимости приобретения дополнительных компетенций для того, чтобы быть конкурентоспособным на региональном рынке труда.

Положительное отношение к труду учителя детей с ЗПР формируется через использование фактологического эмоционально насыщенного материала, развивающего у студентов заинтересованность в освоении профессии. Используется технология критичного чтения текстов из истории коррекционно-развивающего обучения, из биографий известных дефектологов; организуются мастер-классы и творческие мастерские преподавателей и ведущих педагогов-практиков, во время которых они транслируют собственные педагогические позиции и обмениваются личностными смыслами с будущими коллегами. Постоянно проводится самооценивание мотивов к труду учителя детей с ЗПР. Предлагается написание эссе или мини-сочинений: «Профессиональное кредо учителя детей с ЗПР», «Трудно ли быть педагогом детей с ЗПР?», «Какой он, педагог детей с ЗПР?», «Что важнее для учителя: быть личностью или профессионалом?».

Специфика направленности личности педагога детей с ЗПР рассматривается не только на лекционных и практических занятиях в вузе, но и во время самостоятельной работы дома. На информационном ресурсе «ВКонтакте» в группе «Современный учитель детей с ЗПР» создается тема: «Кто он, современный учитель детей с ЗПР?» или «Профессия учителя как средство самовыражения, саморазвития, обретения смысла жизни», где 
будущие дефектологи высказывают свои мнения, опубликовывают ссылки на различные сайты с обсуждением похожей проблематики, книги, статьи, отзывы, что существенно обогащает представления студентов о специфике профессиональной педагогической деятельности.

На протяжении всего периода обучения важно формировать у студентов оценку собственной учебной деятельности как необходимого этапа овладения профессией, как важное условие положительных личностных изменений. Можно предложить студентам составить индивидуальный план изучения учебной дисциплины. Это обеспечивает развитие мотивации к изучению курса и осознанию значимости таких профессионально-личностных качеств педагога как потребность в знаниях, увлечённость процессом познания, самообразования и др. Кроме всего такой прием ориентирован на формирование у студентов ответственности за овладение профессией, за способы освоения ключевых компетенций [5].

По итогам изучения учебной дисциплины осуществляется самооценивание студентами сформированных знаний, умений и навыков. Студентам предлагается в контексте осваиваемых компетенций сформулировать перечень своих учебных достижений и проранжировать их. Такая работа направлена на выстраивание индивидуальной иерархии сформированных профессионально важных компетенций и определение путей из совершенствования.

Интерес к профессии развивается во время работы в качестве волонтеров на региональном конкурсе профессионального мастерства «Дефектолог года», во время встреч с членами общественной организации педагоговдефектологов. Встречи с практиками, находящимися на разных уровнях профессионализма, определяют для студентов ориентиры их собственного профессионального развития. Знание профессиональных норм и навыков профессионального поведения закладывают основы деонтологической подготовки обучающихся [6].

Решение основных задач производственной (педагогической) практики способствует формированию у студентов первичного опыта профессиональной деятельности в учреждениях для детей с ЗПР. Данный опыт выступает, по нашему мнению, основой для развития профессионального интереса студента к тому или иному виду будущей деятельности, впоследствии выражающийся в выборе своей научной темы и места прохождения производственной практики, что, в свою очередь, определяет место будущей работы и карьерный путь. Во 
время практики студенты изучают перспективное и недельное планирование учебно-воспитательной работы в классе; конспекты уроков по предметам начальной школы с использованием коррекционных технологий; конспекты воспитательных мероприятий педагогов, конспекты коррекционных занятий с младшими школьниками с задержкой психического развития; выполняют квалиметрическую оценку проведенных учителями уроков; описывают свое участие в подготовке родительского собрания и заседании психолого-медикопедагогического консилиума и др. По итогам посещения каждого учреждения студенты не только характеризуют его деятельность, но и описывают в дневнике свои ощущения и впечатления, выражают свое отношение к избранной профессиональнойессии, определяя, таким образом, свое место в ней. Безусловно, первая практика способствует эффективному формированию профессиональной направленности студентов, развитию у них чувства принадлежности к профессии и ответственности за овладение профессиональными знаниями и умениями [7].

Применение творческо-познавательных ситуаций в процессе организации научно-исследовательской работы студентов связано с выполнением ими учебно-исследовательской работы по учебным дисциплинам «Специальная педагогика», «Специальная психология», «Психолого-педагогическая диагностика и комплектование коррекционно-образовательных учреждений», «Общеметодические аспекты обучения в специальных образовательных учреждениях», «Обучение в классах КРО», «Психолого-педагогические технологии работы с детьми с ЗПР». В данной деятельности создаются условия для индивидуальной познавательной самостоятельной работы студентов, включающей поиск новых знаний, актуализацию имеющихся умений и навыков подготовки научных рефератов, формирование аналитических способностей и творческого мышления.

При написании учебно-научных работ студент знакомится с логикой научных исследований в области специальной педагогики и психологии и частных отраслей, учится анализировать психолого-педагогическую и дефектологическую литературу, пользоваться теоретическими и эмпирическими методами исследований. В процессе подготовки учебнонаучных работ студент усовершенствует умения и навыки использования приобретенных дефектологических знаний, научной и справочной литературы, осваивает приемы и методы работы с детьми с задержкой психического 
развития на практике, а также овладеет необходимой техникой количественной и качественной обработки полученных данных [8].

Неотъемлемым элементом системы профессиональной подготовки является общественная деятельность студентов. Традиционными для первокурсников являются конкурсы профессиональной направленности «Дефектологический марафон», «Идея», «Дефектолог года». Студенты младших курсо выступают помощниками старшекурсников в организации различных научных студенческих мероприятий, что способствует развитию их организаторских умений, формированию активной жизненной позиции. Будущие дефектологи активно принимают участие в областных научнопрактических семинарах по проблемам дефектологии, организуемых как кафедрой специальной педагогики и психологии ВГСПУ, так и организациямипартнерами по инновационной деятельности (дошкольными и школьными образовательными организациями, реабилитационными центрами для детей с нарушениями интеллектуальной сферы, общественными организациями и объединениями).

На втором этапе профильной подготовки педагогов-дефектологов к работе с детьми с ЗПР в вузе реализовывались аргументативные педагогические ситуации, в которых у студентов формируется и развивается способность на основе реального постижения объективного мира объяснять его. Главная цель, которую должны достичь в специально смоделированных условиях обучающиеся, убедить реципиента согласиться с идеей субъекта. Весь комплекс знаний и умений, разноаспектных профессиональных компетенций востребован в этих ситуациях студентами. Начиная от социально-исторических факторов, влияющих на выбор аргументов, и заканчивая личным профессиональным опытом, и их структурирование в процессе аргументации [9].

Педагогические ситуации этого этапа направлены на формирование активного отношения к окружающей действительности и к себе, формирование профессионального самосознания. Используемые педагогические технологии (реализация педагогических проектов, участие в организации различных мероприятий профессиональной направленности, участие в деятельности общественных объединений, курсы повышения квалификации, стажировки в избранной сфере деятельности в образовательных учреждениях, реализация учебно-научной деятельности и др.) способствовали включению студентов в реальные профессиональные отношения. 
В структуре магистерской программы ключевым для данного этапа подготовки является курс «Подготовка специалистов для работы с детьми с ЗПР в условиях современных ФГОС» [10].

Освоение компетенций в рамках курса «Подготовка специалистов для работы с детьми с ЗПР в условиях современных ФГОС» направлено на повышение психолого-педагогической компетентности педагогов, работающих с детьми с ЗПР, создание условий для освоения современных психологопедагогических технологий в сфере профессиональной деятельности. На занятиях этой дисциплины у обучающихся формируются современные взгляды на задержку психического развития, осмысливаются представления о психологических особенностях младших школьников с ЗПР как основе их трудностей в обучении. Магистранты изучают систему нормативно-правовых документов в сфере коррекционно-развивающего образования детей с ЗПР. У студентов на основе овладения теоретико-методическим инструментарием и технологиями обучения школьников с ЗПР формируются умения проектировать урочную и внеурочную деятельность младших школьников с задержкой психического развития; проводить мониторинг эффективности урочной и внеурочной деятельности. В целом это обеспечивает формирование творческого подхода к решению образовательных, коррекционно-развивающих, воспитательных, социальных задач обучения школьников с задержкой психического развития.

На практических и лабораторных занятиях применяются современные образовательные стратегии обучения (на основе опыта, обучение в практике, проектного обучения) и технологии обучения: тренинг умений, семинармастерская, ситуационное обучение (кейс-метод), метод проектной деятельности с последующей презентацией и защитой проекта, технология «Развитие критического мышления через чтение и письмо»; виртуальные информационные экскурсии (с целью поиска необходимой информации) и др.

В рамках освоения раздела «Дети с ЗПР - объект изучения, воспитания и обучения» проводится анализ текстов, решаются педагогические задачи, магистранты оформляют эссе на заданную тематику. Например, предлагаются темы: «Развитие цивилизации как причина задержанного развития», «Дети с задержкой психического развития: взгляд вчера и сегодня», «Обучаемость и обученность. Что важнее для развития школьника?». Размышляя в русле заявленной темы, магистранты обобщают и структурируют освоенный материал, упражняются в аргументации собственного взгляда на проблему.. 
По разделу «Нормативно-правовые основы коррекционно-развивающего образования детей с ЗПР » используются:

- анализ текстов (нормативных актов);

- ситуационное обучение «Консультация для педагогов и родителей», которая предполагает обсуждение разработанных студентами кейсов;

- индивидуальная проектная деятельность, по итогам которой магистранты представляют к защите презентацию электронных или видеоматериалов. Это может быть оформление таблицы по проблемам обучения детей с ЗПР одной из групп, описанной во ФГОС НОО обучающихся с ОВЗ в русле АООП НОО обучающихся с ЗПР; или кейс на одного ребенка, включающий данные анамнеза, диагноз, характеристику обучаемости, предполагаемый уровень социопсихологической адаптации и описание прогноза трудностей в обучении и воспитании.

По разделу «Образование детей с ЗПР в контексте современных ФГОС» запланировано использование:

- $\quad$ работы с текстом и виртуальных информационных экскурсий с целью поиска необходимой информации

- метода мозгового штурма для обобщения результатов самостоятельной работы;

- семинар-мастерская в рамках которой проводится тренинг умений магистрантов по составлению разделов «Адаптированной основной образовательной программы для обучающихся с ЗПР», разработке организационных моделей внеурочной деятельности, проведению мониторинга эффективности внеурочной деятельности и др.

По разделу «Профессиональная деятельность учителя в системе коррекционно-развивающего обучения» запланирована, в том числе, работа с текстами. Студентам предлагается, прочитав текст, обсудить его в минигруппах и высказать свое мнение с использованием доказательной базы из теории и практики специальной педагогики и психологии и собственного опыта.

На занятиях также проводится тренинг умений, который создает условия для формирования умений магистрантов учитывать психологические особенности детей данной категории при разработке индивидуального образовательного маршрута, умений создавать специальную коррекционноразвивающую среду для ребенка в различных образовательных условиях, умений работы в команде разнопрофильных специалистов и родителей. 
Проявление ценностных ориентаций и смыслов профессиональной деятельности педагога-дефектолога для детей с ЗПР у магистрантов программы «Обучение и воспитание детей с ЗПР» актуализируются в процессе проектирования и реализации индивидуальных и групповых проектов («Модель регионального коррекционно-развивающего образования», «История коррекционно-развивающего образования в лицах», «Профессиональный стандарт педагога: позиция учителей и родителей», и др.). На это нацелена и работа студентов над проблемными эссе («Какими должны быть условия обучения детей с ЗПР?», «Современный УМК для детей с ЗПР: каким я его вижу?», «Как оценивать учебные достижения школьников с задержкой психического развития?» и др.)

Профессиональная социализация обучающихся происходит также во внеучебной работе, реализуемой в академических мероприятиях: всероссийский конкурс статей «Современные проблемы науки и образования глазами школьников и студентов», международный научно-практический семинар «Специальное и интегрированное образование: организация, содержание, технологии». Во время этих проектов студенты пробуют свои силы в организации совместной деятельности с детьми, создают коррекционноразвивающую среду для развития их самостоятельности, творчества с учетом индивидуальных типологических особенностей.

Педагогические технологии этого этапа обеспечивают развитие умений аргументировано отстаивать свою точку зрения, способствуют формированию личной ответственности обучающегося за используемые коррекционноразвивающие технологии в реальном педагогическом процессе, за принятые организаторские решения. На этом этапе широко использовались самостоятельная организация магистрантами различных мероприятий профессиональной направленности. Например, областной семинар «Коррекционная направленность обучения детей с ЗПР»; работа проблемной секции в рамках всероссийской конференции «Коррекционное обучение - опыт регионов»; подготовка информационных буклетов для педагогов и родителей детей с ЗПР, обращающихся в консультативные пункты; участие в деятельности Волгоградской региональной общественной организации «Поддержка профессионального становления педагогов-дефектологов», курсы повышения квалификации, стажировки в избранной сфере деятельности в образовательных учреждениях, реализация научно-исследовательской деятельности, в том числе по запросам образовательных организаций, участие в 
реализации научных грантов др.). Как отмечает А.А. Андрюнина, переосмысление ценностей и переструктурирование мотивов профессиональной деятельности осуществляется тогда, когда студент от репродуктивных действий переходит к творческому выполнению заданий [11].

Критериями эффективности реализации аргументативных педагогических ситуаций выступают:

- способность к комбинированию профессиональных компетенций из разных областей профессиональной деятельности в соответствии с необходимостью доказывать и отстаивать свою точку зрения на профессиональные ситуации, способность к поиску новых знаний и практических решений, к выбору адекватных действий;

- готовность к совершенствованию собственной профессиональной деятельности; готовность к проектированию и моделированию и др.;

- положительное отношение к профессионально-личностному развитию;

- потребность в самореализации на основе системы ценностных ориентаций и смыслов профессиональной деятельности.

Tретий этап профессиональной подготовки в вузе педагога-дефектолога к работе с детьми с ЗПР - период познавательной самостоятельности и профессионально-творческой активности. Активность педагога-дефектолога для работы с детьми с ЗПР в современных условиях имеет особое значение. Изменения нормативно-правовой базы образования, апробация различных организационных форм обучения и воспитания детей с задержкой психического развития требуют от педагога самостоятельности в выборе программного обеспечения и технологий коррекционно-развивающего процесса. Профессионально-творческая активность побуждает к поиску значимой дефектологической информации и ее носителей, определяет успешность профессиональной социализации и профессиональную самореализацию выпускника.

На третьем этапе профессиональной подготовки приоритет отдается индивидуальной научно-исследовательской деятельности, в рамках которой студент-магистрант осуществляет реализацию разработанного собственного педагогического проекта, проходит стажировку по избранной специализации в конкретном образовательном учреждении, проводит комплексное самостоятельное научное исследование. Данные технологии требуют от студентов актуализации их профессиональных знаний и умений, роста их 
самостоятельности и инициативы, формирования потребности в выработке индивидуального стиля собственной жизнедеятельности. Овладение творческой педагогической деятельностью происходит в процессе моделирования и во время осуществления научно-исследовательской деятельности. Формирование способности к преобразованию воображаемых объектов и проверка эффективности таких изменений на практике является ключевой задачей этого этапа профессиональной подготовки педагогадефектолога для работы с детьми с ЗПР.

Педагогические ситуации этого этапа рассматриваются нами как преобразовательные. Преобразовательные педагогические ситуации - это педагогические задачи, решение которых требует нетрадиционных подходов, и которые направлены на раскрытие творческого потенциала личности студента, на развитие способности оценивать и активно преобразовывать профессиональную компетентность и предмет профессиональной деятельности. Формирование способности к изменению материального бытия на третьем этапе профессиональной подготовки педагога-дефектолога для работы с детьми с ЗПР решается через комплекс методов: убеждение, пример, понимание и др.

Педагогические ситуации третьего этапа характеризуются содержанием и формами различных видов практик. Педагогические технологии требуют от студентов активизации профессионально-творческого потенциала, роста самостоятельности и инициативы, актуализированной потребности в проявлении индивидуального стиля профессиональной деятельности. Именно практики создают условия для развития умений критического анализа, осмысления, проектирования и самопроектирования сферы своей деятельности, формируют способность определять свое место в «культурно-образовательном ландшафте» (Е.В. Бондаревская) и создавать личностно-ориентированное образовательное пространство.

Итоговым результатом производственной (педагогической) практики магистрантов выступает сформированная способность к моделированию и педагогическому сопровождению образования лиц с ЗПР и оптимизации социально-средовых условий их жизнедеятельности, а также овладение умениями по сопровождению процесса обучения будущих дефектологов.

Еще до практики магистрант разрабатывает критерии оценки организационных форм и методов обучения и воспитания в дошкольных и школьных образовательных учреждениях коррекционной направленности; 
критерии профессиональной компетентности и результативности деятельности педагогов образовательного учреждения, подбирает диагностический инструментарий для оценивания. Такая работа позволяет сформировать у магистрантов способность разрабатывать аттестационные измерительные материалы, задавать критерии и параметры оценивания полученных результатов, определять проблемные (критические) области. Материалы оформляются в виде, удобном для представления результатов подготовительной работы (презентация, портфолио, банк тестов и т.д.).

На установочной конференции магистранты выступают с сообщением о результатах подготовительной работы. В ходе обсуждения оформляется рабочий вариант критериальной базы, которая позволит практикантам оценить деятельность учреждения в целом и субъектов специального (коррекционного) образования.

Приступив к педагогической практике, магистранты знакомятся с общей характеристикой деятельности учреждения: полным названием, организационно-правовой формой, адресом, численностью педагогических работников и иного персонала; историей создания и развития учреждения; миссией, целями и задачами; основными видами деятельности; внутренней и внешней документацией (должностными инструкциями персонала; трудовыми договорами; договорами о сотрудничестве с партнерами и пр.); директивными и инструктивными материалами.

Затем проводится анализ образовательных программ и комплекта учебно-методической литературы, используемой в учреждении.

Магистрант изучает специфику деятельностью заместителя директора (по научной работе); изучает и анализирует структуру методической службы учреждения; изучает и анализирует различные аспекты деятельности и реализуемые в учреждении образовательные технологии.

Содержание практики включает также разделы, обеспечивающие формирование у магистрантов диагностико-прогностических умений:

Например, Раздел 1. «Изучение уровня обученности младших школьников с ЗПР» нацелен на определение путей совершенствования педагогического сопровождения социализации в специальном (коррекционном) учреждении.

Путем изучения характеристик детей, дневников наблюдений, выписок заключений ПМПК, контрольных срезов и т.д. магистранту необходимо провести диагностическое изучение детей. По итогам оформляется бланк 
«Сведения об обучающихся, воспитанниках». Это позволит оценить контингент учащихся данного образовательного учреждения и разработать условия оптимизации коррекционно-развивающего процесса.

Раздел 2. «Оценка профессиональной компетентности педагогов» программы практики предполагает освоение магистрантами умений по выявлению уровня профессиональной компетентности педагогов и их резервных возможностей в повышении квалификации.

Магистранты проводят анкетирование субъектов коррекционноразвивающего процесса по предлагаемой форме, адаптировав к реальным условиям имеющийся в литературе тестовый диагностический материал («Изучение готовности педагога к самоконтролированию своей деятельности», Определение перспектив профессиональной деятельности педагога», «Отношение педагога к инновационной деятельности», «Определение профессиональных интересов педагога», «Диагностика профессиональной подготовки педагога» и др.). По результатам работы магистранты оформляют Диагностическую карту возможностей и затруднений педагогов или Оценочную шкалу профессиональных умений и навыков, или Оценочную шкалу профессионального мастерства

Раздел 3. «Прогнозирование и совершенствование педагогического сопровождения учащихся с ЗПР» позволяет магистрантам освоить технологии прогнозирования и совершенствования процесса коррекционно-развивающей работы в учреждении.

Обобщив материал, полученный при освоении предыдущих разделов, выявив частные проблемы в коррекционно-развивающем педагогическом процессе учреждения, магистрант приступает к обоснованию темы проекта, его цели и задачи, обосновывает технологию работы, определяет этапы и приступает к реализации проектной деятельности в образовательном учреждении. Опытно-экспериментальная работа и диагностика эффективности реализованных условий проектной деятельности, позволят магистранту разработать методические рекомендации для педагогов образовательного учреждения.

C результатами проектной деятельности магистрант выступает на методическом совете учреждения.

Рефлексия по итогам производственной практики магистрантов проводится в форме написания эссе по темам преподавателя или сформулированным самостоятельно. Например, «Могу ли я возглавить 
методическую службу учреждения?», «Я руководитель учреждения. С чего начать?», «Как изменить отношение педагога к инновационной деятельности?» и т.д.

На этом этапе магистрант может оформить результаты педагогической практики в виде научной статьи по проблеме проекта. Результатом прохождения практики также может быть справка о презентации итогов проекта на методическом совете учреждения, справка о внедрении результатов проекта на базе учреждения; иные свидетельства реализации проекта (сертификат участия в семинарах магистрантов и аспирантов, конференциях и т.д.).

Вполне очевидно, что итогом производственной (педагогической) практики магистранта становится расширение сферы профессиональной компетентности, освоение новых профессиональных ролей. Магистрант пробует себя в роли транслятора знаний, помощника в освоении содержания учебной дисциплины и организации самостоятельной работы и даже модератора.

Научно-исследовательская работа магистрантов ведется в течение всего периода обучения в процессе учебной и производственной практик. Целью научно-исследовательской работы является формирование у магистров программы «Обучение и воспитание детей с ЗПР» научно-педагогического мышления и способностей использовать методологию и методы научных исследований личностно значимых проблем в области коррекционноразвивающего образования.

Формирование у обучающихся ценностных ориентаций и направленности на научно-исследовательскую деятельность происходит в процессе диалогового общения с преподавателем - руководителем исследовательской работы и коллегами из числа профессионалов-исследователей, через участие в студенческих конференциях, мастер-классах ученых (открытые лекции Н.М. Борытко, Н.Н. Малофеева, О.С. Орловой, Е.Г. Речицкой, В.В. Серикова и др.).

Освоение магистрами системы знаний и умений в области методологии и методов научно-педагогических исследований в специальной педагогике и психологии осуществляется через изучение и анализ специальной литературы. Полученный массив дефектологической информации позволяет сформулировать теоретические основы, проблематику и принципы психологопедагогического исследования проблем обучения и воспитания детей с ЗПР. 
Таким образом, третий этап реализации образовательной программы «Обучение и воспитание детей с ЗПР» по направлению подготовки 44.04.03 по направлению «Специальное (дефектологическое) образование предполагают углубленную специализированную подготовку студентов в области образования детей и подростков с задержкой психического развития, реализуемое в условиях различных государственных и негосударственных образовательных, социальных структур и структур здравоохранения в различных институциональных условиях. Программа направлена на подготовку выпускников к коррекционно-педагогическому; диагностикоконсультативному и профилактическому; научно-исследовательскому; преподавательскому; организационно-управленческому; культурнопросветительскому видам деятельности. Магистерская программа носит авторский характер, отражает и развивает идеи научных школ вуза и кафедры специальной педагогики и психологии ВГСПУ.

Критериями эффективности реализации преобразовательных педагогических ситуаций выступают:

- способность к преобразованию компетенций из разных областей профессиональной деятельности в соответствии с новыми задачами профессиональной деятельности и/или при изменении направления профессиональной деятельности и необходимостью новизны получаемых результатов деятельности и др.;

- сформированная способность исследовательского интереса, желания и стремления добиться успеха в научно-исследовательской деятельности; операциональная способность, заключающаяся в применении знаний и умений по ведению научно-исследовательской деятельности; способность к самоорганизации научно-исследовательской деятельности; способность к сотрудничеству и кооперации в процессе научно-исследовательской деятельности.

- преобразовательнаянаправленность личности

(способность совершенствовать и изменять профессиональную деятельность; умения способность самостоятельного проектирования и моделирования и др.);

- способность к решению современных проблем науки и специального (дефектологического) образования средствами самостоятельной научной деятельности.

Опыт поэтапного формирования профильной компетентности будущих педагогов для работы с детьми с ЗПР в условиях университетского образования 
позволяет утверждать, что основными принципами проектирования программы подготовки педагогов к работе с детьми с ЗПР в пространстве вуза являются: учет содержательного и организационного единства программ бакалавриата и магистратуры; обеспечение открытости, вариативности, гибкости и мобильности специального (дефектологического) образования; учет региональных условий; приоритет научно-исследовательской деятельности магистрантов; индивидуальная и личностно-ориентированная направленность образования; гуманизация и гуманитаризация содержания обучения в магистратуре.

Обозначенные в основной образовательной программе магистратуры «Обучение и воспитание детей с ЗПР» цели, задачи и ожидаемые результаты освоения программы детерминированы следующими показателями: общемировыми тенденциями развития высшей школы; требованиями ФГОС ВО по направлению «Специальное (дефектологическое) образование»; ситуацией на региональном рынке труда; спецификой конкретного вуза и профессорско-преподавательского состава выпускающей кафедры.

В магистратуре приоритет у педагогических технологий, отличающихся междисциплинарностью, диалогичностью, нелинейным характером, связью с практикой, исследовательской направленностью, ориентацией на достижение личностных результатов обучения, на самостоятельную работу в учебном процессе и неучебной деятельности и пр.

Важным компонентом предлагаемой модели подготовки педагогадефектолога для работы с детьми с ЗПР является повышение методической компетентности преподавателей основных дисциплин и курсов по выбору программы «Обучение и воспитание детей с ЗПР». Это выражается в преобразовании читаемых курсов через включение содержательных разделов, направленных на формирование ценностного отношения к данной категории детей и профессии педагога детей с ЗПР, через включение упражнений на овладение магистрантами технологий достижения детьми с ЗПР предметных, личностных и метапредметных результатов обучения.

Значимым в процессе подготовки педагога к работе с детьми с ЗПР мы рассматриваем осознанный выбор студентом направления своей профессиональной деятельности - педагогическое, научное, научнопедагогическое.

Расширение профессиональных компетенций, направленных на готовность и способность магистранта к работе с детьми с задержкой 
психического развития на предметных уроках - на наш взгляд, ключевое условие подготовки педагога-дефектолога для работы с детьми с ЗПР. И если уровень бакалавриата предполагает освоение студентами знаний на репродуктивном или продуктивном уровне (В.П. Беспалько, И.Я. Лернер, М.Н. Скаткин и др.), для магистрантов ожидаем творческий уровень освоения знаний.

\section{Список литературы}

1. Дворецкая М.А., Лапп Е.А., Шипилова Е.В. Общественная организация волгоградских педагогов-дефектологов как условие профессиональнойессионального становления // М.А. Дворецкая М.А., Е.А. Лапп, Е.В. Шипилова. // Общественные организации и образовательная политика на Юге России в XIX - начале XXI века: история, проблемы и перспективы развития. Материалы межрегиональной научно-практической конференции (27-28 октября 2011 г.). - Ставрополь: Альфа Принт, 2011. - 272 c. - C.195-200.

2. Богоявленская Д.Б. Интеллектуальная активность как проблема творчества: монография. - Ростов-на-Дону: Издательство Ростовского университета, 1983. - 176 с. - С. 166.

3. Шипилова Е.В. Роль активного обучения в профессиональнойессиональном становлении студентов-дефектологов/ Е.В. Шипилова // Специальное и интегрированное образование: организация, содержание, технологии. Материалы I Международного научно-практического семинара, г.Волгоград, 27-28 октября 2011 г. / редкол.: Е.А. Лапп (отв.ред.) и др. - Волгоград: Изд-во ВолГУ, 2011- 280 с. - С. 60-64.

4. Афанасьева Н.А. Самоорганизация - фактор успешности учебной деятельности / Н.А. Афанасьева // Фундаментальные исследования. - 2008. - № $2-$ C. $60-61$.

5. Семушкина, Л.Г. Разработка методики контроля готовности к профессиональнойессиональной деятельности студентов ссузов/ Л.Г. Семушкина // Среднее профессиональнойессиональное образование. 2003. - № 10 . - C.2 - 6 . 
6. Филатова И.А. Деонтология в специальной педагогике: теоретикометодологические основания исследования деонтологической подготовки педагогических кадров: монография / И.А. Филатова; Урал. гос. пед. ун-т. Екатеринбург, 2011. - 177 с.

7. Аслаева Р.Г. Дневник учебной практики в специальных (коррекционных) классах VII вида: учебное пособие для обучающихся по направлению подготовки «Специальное (дефектологическое) образование» профиль подготовки «Олигофренопедагогика»

Р.Г. Аслаева, Е.А. Лапп, Л.В. Суфьянова. - Волгоград: ВолГУ, 2013.

8. Учебно-научная и научно-исследовательская деятельность бакалавра: учебное пособие / Лапп Е.А. - Волгоград: Изд-во «ВолГУ», 2012. - 77 с.

9. Брюшинкин В.Н. Аргументация, коммуникация, рациональность //Вестник Балтийского федерального университета им. И. Канта. 2008. Вып. № 6.С. 5-12.; Колесова Д. В. Аргументация как тип текста /Язык, литература, культура: Актуальные проблемы изучения и преподавания: Сб. научных и научно-методических статей/Ред.коллегия: Л. П. Клобукова и др. М.: МАКСПресс, 2013. С.42-53.

10. Обучение и воспитание детей с ЗПР: проектирование и реализация процесса подготовки будущих дефектологов: учебное пособие / Е.А. Лапп, М.Н. Серенко, В.Г. Яриков, С.Г. Ярикова. - Волгоград: ВолГУ, 2018 - 424 с. 424

11. Андрюнина А.С. Формирование профессиональнойессиональных ценностей у будущих педагогов: проблемы и решения / Андрюнина А.С. Педагогическое образование в России. - 2013. - № 5. - С.205-209.

12. Митяева А.М. Развитие индивидуальных стилей учебной деятельности студентов: Монография. Орел, 2005. - 175 с. 
УДК 796.417.2

\title{
ДИФФЕРЕНЦИРОВАННЫЙ ПОДХОД К ОБУЧЕНИЮ \\ БАЛАНСОВЫХ ЭЛЕМЕНТОВ СПОРТИВНЫХ АКРОБАТОК, СПЕЦИАЛИЗИРУЮЩИХСЯ \\ В ЖЕНСКИХ ГРУППОВЫХ УПРАЖНЕНИЯХ
}

\author{
Ильичева Виктория Андреевна \\ Жигайлова Лариса Валентиновна \\ к.П.н., доцент \\ Береславская Наталья Вадимовна \\ к.п.Н., доцент \\ Тронев Вячеслав Вячеславович
}

Аннотация: Постоянное повышение уровня конкуренции на соревновательных мероприятиях по спортивной акробатике можно считать результатом непрерывного совершенствования тренировочного процесса акробатов. В настоящее время данный вид спорта завоевал множество значительных высот по показателям демонстрируемых результатов, технической сложности выполняемых упражнений и зрелищности, которую показывают акробаты во время выступлений. В этой связи следует отметить рост популярности спортивной акробатики и как следствие ежегодное увеличение численности занимающихся.

Данный факт ставит перед современным тренерским коллективом задачи реализации спортивной подготовки наиболее эффективным способом. Одной из основных задач следует выделить необходимость подготовки соревновательных элементов, на высоком уровне исполнения технической составляющей, с демонстрацией стабильности и надежности выполнения соревновательных упражнений [1, с. 564-565].

Выполнение сложных акробатических упражнений, связанных с сохранением равновесия, требует даже от квалифицированных спортсменов высоких физических показателей, легкости, оригинальности и стабильности их исполнения. Изучение проблемы совершенствования технической подготовки балансовых упражнений в спортивной акробатике показало, что в научнометодической литературе не в полной мере раскрыт вопрос по данной теме. Также наблюдается отсутствие эффективных методик повышения качества 
исполнения балансовых упражнений акробаток, специализирующихся в женских группах.

Ключевые слова: спортивная акробатика, женские групповые упражнения, совершенствование технической подготовленности.

\title{
DIFFERENTIATED APPROACH TO TRAINING BALANCE ELEMENTS OF ACROBATS WOMEN'S GROUP EXERCISES
}

\author{
Victoria Andreyevna Ilyicheva \\ Jigalova Larisa Valentinovna \\ Bereslavskaya Natalia Vadimovna \\ Tronev Vyacheslav Vyacheslavovich
}

\begin{abstract}
The constant increase in the level of competition at competitive events in sports acrobatics can be considered the result of continuous improvement of the training process of acrobats. Currently, this sport has won many significant heights in terms of the results demonstrated, the technical complexity of the exercises performed, and the entertainment that acrobats show during performances. In this regard, we should note the growing popularity of sports acrobatics and, as a result, the annual increase in the number of participants.

This fact sets the modern coaching team the task of implementing sports training in the most effective way. One of the main tasks is to highlight the need to prepare competitive elements, at a high level of performance of the technical component, with a demonstration of stability and reliability of performing competitive exercises.

Performing complex acrobatic exercises related to maintaining balance requires high physical performance, ease, originality and stability of their performance even from qualified athletes. The study of the problem of improving the technical training of balance exercises in sports acrobatics has shown that the scientific and methodological literature does not fully disclose the issue on this topic. There is also a lack of effective methods to improve the quality of balance exercises performed by acrobats who specialize in women's groups.
\end{abstract}

Key words: sports acrobatics, women's group exercises, improvement of technical readiness. 


\section{Классификация групповых упражнений}

В России женские группы начали развиваться в 1973 году. В спортивной акробатике этот вид в короткие сроки стал наиболее зрелищным и красивым. Большую роль в этом сыграло введение музыкального сопровождения, что предавало каждой композиции свою уникальность.

Также свой вклад в зрелищность внесли и большой запас движений, который использовали акробатические «тройки»: прыжки, элементы на гибкость, разные пирамиды, хореография и динамические элементы.

Согласно современной классификации в спортивной акробатике, у женских групп упражнения, направленные на выполнение статических и силовых (балансовых) элементов являются одним из трех основных упражнений в соревновательной программе.

В балансовых упражнениях спортсмены выполняют элементы на бедрах партнера, ступнях или плечах. Оценивается при этом легкость и оригинальность выполнения элемента, её трудность, а также продолжительность фиксации не менее 3 секунд каждого положения, согласованность и точность схода или соскока [2, с. 110-112].

Участники групп выполняют следующие роли:

Нижняя - акробатка, находящаяся в основании пирамиды, и выполняющий основную роль в бросках и ловле;

Средняя - акробатка, находящаяся в пирамиде на нижнем ярусе и удерживающий вышестоящего партнера; в бросках и ловле участвует вместе с нижней или самостоятельно;

Верхняя - акробатка, завершающая в тройках построения стойками, упорами, поддержками, равновесиями. В вольтижных упражнениях выполняет полеты, курбеты, перевороты, сальто то одного партнера к другому, от одного к двум, от двух к одному и другие варианты и сочетания с их помощью.

Благодаря заметным росто-весовым различиям между партнерами, групповые виды акробатики стали доступны для широкого круга занимающихся различного роста и телосложения.

Немаловажно и значение групповых видов акробатики в воспитании коллективизма, товарищества, взаимопомощи, взаимовыручки, ибо только при наличии этих качеств, группа может рассчитывать на выполнение спортивных разрядов и достижение высоких результатов на соревнованиях [2, с. 113-117].

Для более подробного описания проводимого исследования следует привести несколько определений, характеризующих балансовые элементы. 
Пирамида - групповое размещение акробаток в виде композиционно оформленной фигуры. Пирамиды разнообразны по количеству исполнителей, композиционному рисунку и сложности.

Рассмотрим пирамиды для женских и мужских групп, используемые в спортивной акробатике. Они классифицируются по количеству партнеров, составляющих основание пирамиды и по положению среднего на них (рис. 1).

Построение пирамиды - поочередные или одновременные входы партнеров и занятие ими определенного положении я, включая выполнение верхним стойки, упоры, поддержки или равновесия.

Фиксация балансовой пирамиды - удержание завершенного положения, согласно требованиям правил соревнований по виду спорта -3 сек.

Сход с пирамиды - поочередное или одновременное спрыгивание с пирамиды, предусмотренное описанием или правилами соревнований по виду спорта. 


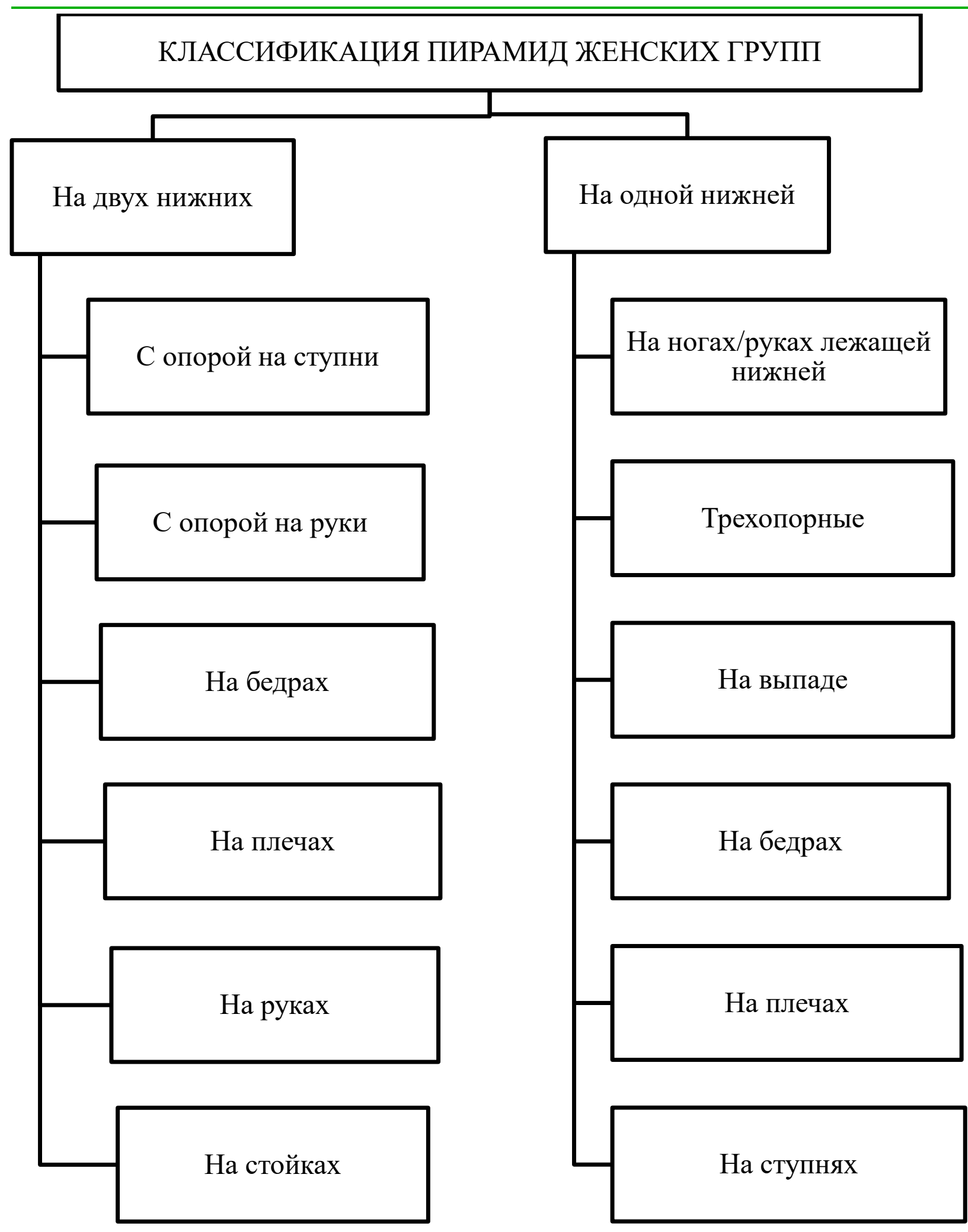

Рис. 1. - Классификация балансовых построений (пирамид) в женских группах 
Разрушение пирамиды - не предусмотренное описанием или правилами соревнований спрыгивание партнеров ранее соскока верхнего или изменением направления техники [3, с. 64-66].

Тенденции развития трудности упражнения в спортивной акробатике, помимо элементов одной конфигурации, широко используют и элементы с парной работой и переходные.

\section{Особенности обучения балансовым элементам \\ в женских групповых упражнениях}

Балансовые упражнения в спортивной акробатике включают в себя разнообразные комбинации стоек, поддержек, выпадов, упоров, мостов и шпагатов.

Важную роль при выполнении статических элементов играют хваты партнеров от правильности, выполнения которых зависит умение балансировать и легко выполнять парно-групповые упражнения. Виды хватов, используемые в спортивной акробатике, представлены в табл. 1 [3, с.65-69].

\section{Таблица 1}

\section{Разновидности хватов в спортивной акробатике}

\begin{tabular}{l}
\multicolumn{1}{c|}{ Описание хвата } \\
$\begin{array}{l}\text { Обычный хват (простой) - партнеры } \\
\text { соединяют одноименные руки, указательный } \\
\text { и средний пальцы, обхватывают запястье. } \\
\text { При выполнении стоек они разведены меньше } \\
\text { или соединены и упираются в нижнюю часть } \\
\text { предплечья }\end{array}$ \\
$\begin{array}{l}\text { Лицевой хват - хват, при котором правая рука } \\
\text { соединяется с левой рукой партнера }\end{array}$ \\
\hline
\end{tabular}




Глубокий хват - захват рук партнера на
уровне лучезапястного сустава. Может быть
обычным и лицевым
Плечевой хват - выполняется выше локтевого
сустава или под плечи
Хват за большие пальцы - хват за большие
пальцы может быть только одноименным

Обучения балансовым элементам делиться на 4 этапа.

1 этап. Разделить «пирамиду» на части и выполнить их отдельно в парах («нижняя» и «средняя», «средняя» и «верхняя»). Важно определить правильное и удобное сцепление между партнерами.

2 этап. Обучение технически правильному выполнению элемента. Устойчиво выполнять вход в элемент, сохранять гибкость и натянутость тела, удерживать статическое положение, согласно рекомендациям в правилах соревнований по спортивной акробатике. На данном этапе элемент сопровождается страховкой тренера.

3 этап. Довести элемент до автоматизма. Выполнение элемента не должно вызывать страх, допускаются в основном незначительные технические ошибки.

4 этап. Совершенствование балансового элемента. Это длительный этап в период, которого устраняются все мелкие технические ошибки и выполнение элемента приближено к идеальному [4, с. 11-21].

Рассмотрим поэтапно методику обучения для балансового элемента «Мост», приведенную в табл. 2. 
Таблица 2

\section{Методика обучения балансовому элементу «Мост»}

\begin{tabular}{|c|c|c|}
\hline Балансовый элемент & Дозировка & Методические указания \\
\hline \multicolumn{3}{|c|}{1 этап } \\
\hline Парное выполнение «нижней» и «средней» & 3 раза & $\begin{array}{l}\text { «нижней» обеспечить } \\
\text { удобную и устойчивую } \\
\text { опору для «средней». } \\
\text { «средней» принять } \\
\text { правильное положения, } \\
\text { регламентируемое в } \\
\text { правилах соревнований. }\end{array}$ \\
\hline Парное выполнение «средней» и «верхней» & 5 раз & $\begin{array}{l}\text { «верхней» сохранять } \\
\text { точное положение, не } \\
\text { опускать голову и ноги } \\
\text { ниже горизонтальной } \\
\text { линии. } \\
\text { «средней» обеспечить } \\
\text { удобную и устойчивую } \\
\text { опору для «верхней». }\end{array}$ \\
\hline \multicolumn{3}{|c|}{2 этап } \\
\hline Выполнить втроем со страховкой тренера & 10 раз & $\begin{array}{l}\text { Отработать быстрый и } \\
\text { аккуратный вход в } \\
\text { пирамиду, не нарушая } \\
\text { дальнейшую технику } \\
\text { выполнения элемента. }\end{array}$ \\
\hline \multicolumn{3}{|c|}{3 этап } \\
\hline Доведение элемента до автоматизма & $10-15$ раз & $\begin{array}{l}\text { Выполнять элемент } \\
\text { самостоятельно } \\
\text { Исправление ошибок } \\
\text { Анализ неудачных } \\
\text { подходов }\end{array}$ \\
\hline \multicolumn{3}{|c|}{4 этап } \\
\hline Совершенствование выполнения элемента & 10 раз & $\begin{array}{l}\text { Контроль и коррекция } \\
\text { выполняемого элемента } \\
\text { Сохранение устойчивого }\end{array}$ \\
\hline
\end{tabular}




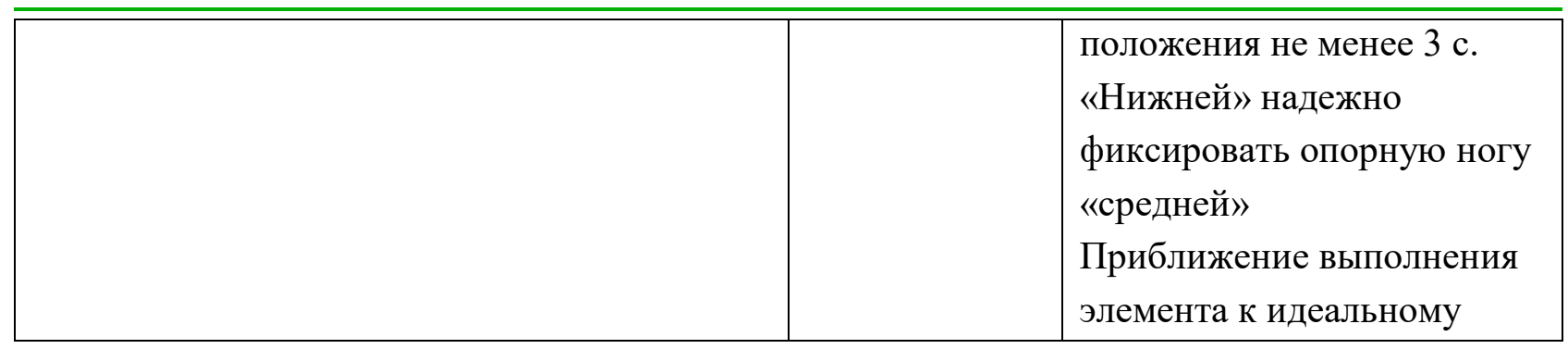

Данная методическая последовательность, представленная в таблице 2, способствует более оперативному обучению сложно-координационных элементов и сводит к минимуму грубые технические ошибки.

\section{Программа совершенствования балансовых элементов}

\section{в групповых упражнениях}

В настоящее время в научной литературе нет достаточного количества эффективных методик, которые можно было бы применить для совершенствования выполнения балансовых элементов в женских групповых упражнениях. Их важность велика, так как иногда решающую роль в соревновательной оценке играют не только 0,1 балл, но и 0,01 и 0,001 балла [5, c. 8-13].

В связи с вышесказанным, была предложена программа совершенствования выполнения балансовых элементов на примере акробатического построения «Мост» (табл. 3). «Мост» имеет множество вариаций сложности, в нашем случае «нижняя» и «средняя» выполняли 1 базовое построение с опорой на одну руку. «Верхняя» выполняла 2 элемента: упор углом вне и «крокодил».

Таблица 3

Программа совершенствования балансовых элементов

в женских групповых упражнениях

\begin{tabular}{|c|c|c|}
\hline Балансовый элемент & Дозировка & Методические указания \\
\hline \multicolumn{3}{|c|}{1 этап } \\
\hline $\begin{array}{l}\text { Упражнение для «нижней» } \\
\text { И.П. - стоя в положении полумост, в } \\
\text { свободную руку, взяв утяжелитель } \\
\text { (гантеля, «стоялка»и т.д.) } \\
\text { 1- удержание, } 2 \text { - И.П. }\end{array}$ & $3 \times 30 \mathrm{c}$ & $\begin{array}{l}\text { Контролировать положение } \\
\text { свободной руки } \\
\text { Не отводить руку от исходного } \\
\text { положения. } \\
\text { (то же самое выполнить на другую } \\
\text { руку) }\end{array}$ \\
\hline
\end{tabular}




\begin{tabular}{|c|c|c|}
\hline $\begin{array}{l}\text { Парное выполнение «средней» и } \\
\text { «верхней» }\end{array}$ & 5 раз & $\begin{array}{l}\text { Переход из положения «угол» в } \\
\text { «крокодил» и обратно в «угол» } \\
\text { Упражнение направленно на } \\
\text { развитие специальной } \\
\text { выносливости у акробаток. }\end{array}$ \\
\hline \multicolumn{3}{|c|}{2 этап } \\
\hline Совместное выполнение всей группой & 5 из 5 раз & $\begin{array}{l}\text { Не засчитывать подходы с } \\
\text { грубыми ошибками } \\
\text { Плавный переход «верхней» из } \\
\text { одного элемента в другой }\end{array}$ \\
\hline \multicolumn{3}{|c|}{3 этап } \\
\hline $\begin{array}{c}\text { Совершенствование выполнения } \\
\text { элемента }\end{array}$ & $\begin{array}{l}10 \text { раз } \\
\text { по } 5 \text { с }\end{array}$ & $\begin{array}{l}\text { Контролировать положения всех } \\
\text { звеньев тела } \\
\text { Не допускать тремора у всех трех } \\
\text { акробаток } \\
\text { Следить за качественными } \\
\text { входами и выходами с элемента }\end{array}$ \\
\hline
\end{tabular}

Данная программа будет разделена на 3 этапа, каждый из них будет реализовывать свойственные им задачи.

На первом этапе спортсменки делают подготовительные упражнения для дальнейшего сложного по координации элемента. «Нижняя» самостоятельно регулирует правильное и устойчивое положение и отдельно «средняя» и «верхняя» выполняют парную работу.

На втором этапе перед спортсменками стоит задача доведения элемента до автоматизма. Для ее реализации требуется выполнить элемент 3 раза подряд, не допуская грубых ошибок. Такой способ приучает акробатов подходить к каждому выполняемому элементу осознанно и бороться за него.

Третий этап включает метод опережающей сложности. В этом случае, несмотря на то, что балансовые элементы фиксируются не менее 3-х секунд, 
спортсмены фиксируют каждое базовое построение по 5 секунд. При таком контрасте в соревновательных условиях, акробатки будут выполнять элемент более уверенно [6, с. 4-8, 7, с. 25-27].

Таким образом, нам удалось конкретизировать содержание тренировочного занятия в процессе совершенствования балансовых элементов для акробаток, специализирующихся в женских групповых упражнения.

\section{Эффективность методики совершенствования балансовых упражнений акробаток, специализирующихся в женских группах}

После завершения эксперимента все спортсменки выступали в официальных соревнованиях по программе кандидатов в мастера спорта. В табл. 4 отражены результаты соревнований балансовых и комбинированных упражнений. Итоговая оценка вольтижных композиций не учитывалась, так как в ее содержание не входят балансовые элементы.

Таблица 4

Результаты соревновательных оценок акробаток, специализирующихся в групповых упражнениях $(\mathrm{n}=21)$

\begin{tabular}{|l|c|c|}
\hline \multirow{2}{*}{ Показатели } & \multicolumn{2}{|c|}{ Вид упражнения } \\
\cline { 2 - 3 } & Балансовые упражнения & Комбинированные упражнения \\
\hline До эксперимента (баллы) & $17,4 \pm 0,1$ & $17,8 \pm 0,2$ \\
\hline После эксперимента (баллы) & $18,1 \pm 0,3$ & $18,5 \pm 0,3$ \\
\hline Процентный прирост & $4,04 \%$ & $3,93 \%$ \\
\hline Критерий Стьюдента & 2,8 & 3,5 \\
\hline Достоверность различий & $\mathrm{p}<0,01$ & $\mathrm{p}<0,05$ \\
\hline
\end{tabular}

Анализируя данные табл. 3, наблюдается высокая степень взаимосвязи с соревновательной оценкой в балансовых упражнениях и средняя степень взаимосвязи в комбинированных упражнениях. По нашему мнению это объясняется значительным количеством допущенных ошибок среди 
вольтижных элементов, а также отсутствием сложных, имеющих высокую стоимость балансовых элементов [8, с. 20-22].

Таким образом, полученные данные позволяют утверждать, что разработанная программа совершенствования балансовых упражнений для акробаток, специализирующихся в женских группах является эффективной и может применяться в спортивной практике.

\section{Заключение}

По результатам проведенных исследований, в ходе решения поставленных в работе задач нами сформулированы следующие выводы:

1. Определены особенности обучения балансовым элементам в женских групповых упражнениях:

- разделить «пирамиду» на части и выполнить их отдельно в парах.

- обучить технически правильному выполнению элемента.

- довести элемент до автоматизма.

- совершенствование балансового элемента.

2. Разработана программа совершенствования балансовых элементов для акробаток, специализирующихся в женских группах, которая способствовала конкретизации содержания тренировочного занятия.

3. Экспериментально проверена программа совершенствования выполнения балансовых элементов. Большая часть результатов корреляции проявила среднюю степень взаимосвязи с соревновательным результатом на уровне $(\mathrm{p}<0,05)$.

\section{Список литературы}

1. Андреенко, Т.А. Методика комплексного использования технических средств на этапе начальной специализированной подготовки акробатов / Т.А. Андреенко, Н.Л. Горячева // Физическое воспитание и спортивная тренировка, 2018. - № 3 (25). - С. 7-15.

2. Бачинская, Н.В. Особенности построения структуры многолетней подготовки в спортивной акробатике на современном этапе / Н.В. Бачинская // Физическое воспитание студентов. - Харьков, 2015. - № 1. - С. 3-10.

3. Березина, А.А. Содержание и структура соревновательных композиций высококвалифицированных акробатов / А.А. Березина, 
Н.Л. Горячева, В.В. Анцыперов, А.А. Мартынов // Современные проблемы науки и образования, 2015. - № 2. - С. 25-29.

4. Горячева, Н.Л. Анализ двигательной деятельности партнеров в парной акробатике / Н.Л. Горячева, В.В. Анцыперов // Фундаментальные исследования, 2012. - №3 (часть3). - С. 563-566.

5. Гусев, Н.П. Эффективные средства совершенствования технического мастерства в групповой акробатике / Н.П. Гусев // Автореф. дис. канд. пед. наук. - М.: 2001. -23 с.

6. Морозевич-Шилюк, Т.А. База соревновательных упражнений акробатов / Т.А. Морозевич-Шилюк // Ученые записки Белорусского государственного университета физической культуры, 2014. - № 17. - С. 110117.

7. Садовский Е.А. Компоненты структуры технической подготовки акробатов / Е.А. Садовская, В.А. Болобан // Теория и практика физической культуры, 2003. - №9. - С. 19-23.

8. Чернова, А.О. Особенности техники и методика обучения балансовым упражнениям нижних партнеров в парной акробатике / А.О. Чернова, А.В. Быкова // Актуальные вопросы физического и адаптивного физического воспитания в системе образования. Материалы I Всероссийской с международным участием научно-практической конференции, 2019. - С. 64-69. 


\section{МЕТОДЫ И \\ ВОЗМОЖНОСТИ \\ ДИСТАНЦИОННОГО \\ ОБРАЗОВАНИЯ}




\title{
УДК 378.016
}

\section{О НЕКОТОРЫХ АСПЕКТАХ ПРИМЕНЕНИЯ ДИСТАНЦИОННЫХ ТЕХНОЛОГИЙ В ПРАКТИКЕ ОБУЧЕНИЯ АНГЛИЙСКОМУ ЯЗЫКУ СТУДЕНТОВ НЕЛИНГВИСТИЧЕСКИХ НАПРАВЛЕНИЙ ПОДГОТОВКИ}

\author{
Ольга Геннадьевна Евграфова \\ к.П.н., доцент \\ Диляра Айратовна Салимзанова \\ к.ф.н., доцент \\ Фарида Ханифовна Сахапова \\ к.П.н, доцент
}

Аннотация: Авторы статьи делятся опытом внедрения цифровых и дистанционных технологий в практику обучения иностранному языку студентов нелингвистических направлений подготовки, актуальность применения которых доказало время и кардинальные изменения в обществе. Доказывается, что применение живых аутентичных материалов с ряда англоязычных сайтов не только актуализирует содержание обучения, но и является мощным стимулом для дальнейшего совершенствования иноязычной подготовки студента, разработки собственной образовательной траектории в обучении. Поднимаются вопросы внедрения в процесс дистанционного обучения проектной методики и использования социальных сетей. На основании проведенного анкетирования и интервью обучаемых, авторы делают вывод о широких возможностях такого обучения.

Ключевые слова: иностранный язык, дистанционное обучение, информационные технологии, социальные сети, открытые онлайн ресурсы, контент, индивидуальный проект, тестирование, анкетирование.

\section{ON SOME ASPECTS OF THE APPLICATION OF REMOTE TECHNOLOGISTS IN THE PRACTICE OF TEACHING ENGLISH LANGUAGE TO NON-LINGUISTIC TRAINING STUDENTS}

Abstract: The authors of the article share the practical experience of introducing digital technologies in the practice of teaching a foreign language to nonlinguistic university students. The relevance of digital technology application into 
teaching practice has been proven by time and dramatic changes in society. It is stated that the use of real authentic materials from a number of Russian-language sites not only actualizes teaching, but also is a powerful incentive for improving the student's foreign language training, developing his own educational trajectory in teaching. The issues of introducing project methods and using social networks into the process of distance learning are raised. Based on the questionnaire survey and interviews with the trainees, the authors conclude that there are ample opportunities for such training.

Key words: foreign language, distance learning, information technology, social networks, open online resources, content, project, questioning.

\section{Введение}

В настоящее время в связи с радикальными изменениями в мировом социуме, обусловленными распространением смертельно опасного вирусного заболевания Covid-19, участившимися природными катаклизмами и вооруженными столкновениями и другими обстоятельствами, как никогда становится актуальной проблема внедрения дистанционного обучения, разработка методологии, распространении положительного педагогического опыта.

Государственные системы все глубже осознают необходимость разработки разнообразных онлайн курсов, цифровых электронных ресурсов применение которых смогло бы обеспечить надежную основу для дистанционного обучения, а также позволяла бы обучаемым учиться по своей образовательной траектории, сделав процесс учебы более гибким, подстроенным по каждого студента.

Дисциплина «Иностранный язык» входит в блок общегуманитарных дисциплин и изучается абсолютным большинством студентов нелингвистических вузов. Языковая подготовка способствует «социализации и профилизации личности специалиста в вузе, формированию поликультурной личности.

Федеральный государственный стандарт по направлению подготовки 04.03.01 «Химия» формулирует общекультурную компетенцию (ОК-5) «выпускник бакалавриата должен обладать способностью к коммуникации в устной и письменной формах на русском и иностранном языках для решения задач межличностного и межкультурного взаимодействия» [5]. 
Следует учесть, что данная дисциплина является средством повышения информированности обучаемого в области профессиональной деятельности, создает условия для формирования профессиональных компетенций. Значительный вклад в разработку теории профессионально-ориентированного преподавания дисциплины «Иностранный язык» внесли П.И. Образцов и др.. Они внесли обоснование принципа профессиональной направленности учебного материала при обучении иностранному языку в неязыковом вузе. Авторы указывали, что изучение иностранного языка должно не должно быть самоцелью, а средство достижения цели повышения уровня эрудиции, образованности в рамках своего направления подготовки. Учет специфики профилирующих специальностей, с их точки зрения, должен проводиться по следующим направлениям: работа над специальными текстами, изучение специальных тем для развития устной речи, изучение словаря-минимума по соответствующей специальности, создание преподавателями пособий для активизации грамматического и лексического материала обучающихся [4].

Таким образом, нами было проведено исследование, какими возможностями обладает современная цифровая среда для более эффективного внедрения дистанционного обучения в практику обучения иностранному языку студентов-химиков, которые по роду своей будущей профессии могут быть вовлечены в научно-исследовательскую, производственно-технологическую, организационно-управленческую, педагогическую деятельность.

\section{1. Использование}

образовательного

контента

TED.ED

\section{дистанционном обучении}

Как отмечают исследователи, и информационные, и коммуникационные технологии - это класс инновационных технологий для быстрого накопления интеллектуального и экономического потенциала стратегических ресурсов, обеспечивающих устойчивое развитие общества [Bilyalova A. ICT in Teaching a Foreign Language in High School. Procedia-Social and Behavioral Sciences 237 (2017) 175-181]. Поскольку в меняющейся образовательной среде все более проявляются новые способы представления научных знаний, накопленного социального опыта, и предметных областей, преподавателями Казанского федерального университета активно внедряется в процесс обучения иностранному языку такие ресурсы как TED.ED и TED.COM.

В условиях карантина (первая волна Ковид-19 в России) и перехода на дистанционный формат обучения нами были отобраны 8 выступлений спикеров знаменитой конференции TED (technology, education, design) по темам, 
коррелирующих с программой по иностранному языку для студентов-химиков. Удобство ресурса в том, что тематика, сложность, длительность, научная сфера может задаваться настройками сайта и, соответственно, подбираться преподавателем исходя из уровня языковой компетенции группы, интересов обучаемых, в том числе, связанными с избранной ими профессиональной областью, наличием сценария выступления. Все выступления идут на английском языке и сопровождаются субтитрами, переведенными на 40 языков. Выступающие делятся собственным опытом, рассуждают о важных проблемах современности, делают выводы, ведут беседу с аудиторией, каждое выступление сопровождается презентацией [7].

Оригинальность и актуальность подачи англоязычного материала подкаста TED.ED, содержащий большое количество видео материала, мультипликационных роликов на различные темы, подтвердили результаты анкетирования студентов в конце весеннего семестра 2019-2020 г.

$82 \%$ опрошенных студентов направления подготовки «Химия» согласились с мнением, что короткие видеоролики на темы «When is a pandemic over?'[11], “The danger of mixing drugs?” [9] и др. мотивировали процесс обучения, заставляли искать незнакомые лексические единицы в словаре, расширяли не только профессиональный, но и академический вокабуляр, а также представления о новых заболеваниях, биохимических процессах в организме человека, о причинно-следственных связях, давали ценные рекомендации. Сложность дидактической задачи вызвала необходимость разработки преподавателем системы упражнений всех трех этапов процесса аудирования - до прослушивания (before listening), во время прослушивания (while listening), после прослушивания (after listening).

Приведем пример, занятия, направленного на развитие навыков аудирования по теме «Illnesses and treatment”. В чате созданной в социальной сети В Контакте закрытой группе «English for special purposes” преподаватель размещает кейс, содержащий в себе проблемную ситуацию: Вы присутствуете на международном форуме, посвященном проблеме распространения новых болезней на планете. В начале общего собрания участников вам показывают видеоролик «When is the pandemic over?” [11] После просмотра видеоролика состоится круглый стол представителей научного сообщества, предусматривающий обсуждение путей выхода из создавшейся ситуации. Задача - представить свое видение проблемы, опираясь на данные статистики, информацию из прессы о путях заражения, способах защиты населения, 
степени разработки препаратов для борьбы с вирусом. Для подготовки своего выступления выполните следующие действия: before listening - a)Read these word combinations aloud and try to guess their meaning or you may use your dictionary - highly infectious, to proliferate fast, to contain, to spread worldwide, pandemic, rates of transmission, to race through it, delay and vaccinate, coordinate, to halt the spread, herd immunity, to give research facilities time, to slow the spread, widespread testing, to identify carries, to coordinate properly. b) answer the questions - Have you ever catch a virus? If yes, when did you have it? What symptoms did you have? When did you hear about a covid-19 for the first time? Where does the virus come from?

while listening - Complete the sentences. 1. Highly infectious, sometimes respiratory virus infected humans. 2 . has declared a pandemic. 3 . Without time to study the virus doctors know little 4. Herd immunity in, where the virus can no longer new hosts. 5. Governments and around the world the spread of the virus to give time to produce a vaccine.

After listening - Decide if it's true (T) or false (F): 1. Covid-19 is a highly infectious, sometimes deadly respiratory virus. 2. At first public health measures knew how to contain it. 3. Pandemic is a deasses spreading worldwide. 4. Governments have 2 main options in this situation. 5. Everyone must treat the world as the giant interconnected system it is. 6. Vaccination, assisted by as much global coordination as possible is generally considered to be the winner.

Последний этап после прослушивания является подготовительным к этапу говорения, который нацелен на умение формировать свое собственное высказывание (выступление во время круглого стола) в соответствии с речевой задачей.

Следует отметить, что в условиях дистанционного обучения данный pecypc TED.ED предлагает также ряд оценочно-тренировочных заданий на проверку понимания просмотренного и прослушанного сюжета. Обучаемые могут открыть разделы Think, где им предлагается выполнить тест он-лайн, содержащий 8 вопросов-заданий по типу один ответ из нескольких предложенных вариантов (1-5 вопросы), а 6-8 задания предполагают создание (написание) собственного ответа на поставленный вопрос. Например, № 7 звучит следующим образом Do you agree with the "Race through it" tactic where the government does nothing to halt the spread of the disease? Why or why not? или 8. When will we know the pandemic is over? When will you feel safe and return to "normal" conditions? Обучаемые имеют возможность зафиксировать свои 
ответы-высказывания прямо в окне сайта, сохранить их, а затем зачитать устно (во время онлайн занятия), либо отправить в чат группы сообщением.

В конечном итоге, задача по формированию речевой, языковой и социокультурной компетенции через организацию пресс-конференции по проблеме, изложенной в кейсе постепенно решается. Этой же цели служат разделы Dig deeper, где слушателем предлагается для знакомства дополнительный материал для чтения по проблеме, а также вкладка Discuss, благодаря которой обучаемые имеют возможность прочитать англоязычные комментарии и письменно обменяться мнениями по следующему вопросу: Out of the three governmental and community tactics, Race through it, Delay and vaccinate, Coordinate and crush, which do you think your country did? Do you feel it was successful? Why or why not?

По результатам анкетирования, целью которого было проанализировать отношение обучаемых к введению контента TED.ED в практику обучения, 71\% первокурсников согласились с мнением, что материалы сайта были интересны, мотивировали к поиску дополнительной информации. 67\% обучаемых согласились, что предлагаемые ресурсом TED.ED тесты заставляли обратится к сценарию видеоролика, организовать прослушивание в своем темпе, делая паузы с целью записать новое, незнакомое выражение, слово, синтагму. Около 90\% студентов признались, что включение титров на английском языке помогало осваивать как лексические единицы (фонетику, графический образ слова, употребление в контексте), так и грамматические структуры. $28 \%$ обучаемых признались, что материалы сайта показались сложными для восприятия, потому им приходилось пользоваться электронными словарями. Однако, большинство студентов (86\%) выразили желание применения данного контента на аудиторных занятиях. Оценивая недостатки данного контента, некоторые студенты (24\%) выразили неудовлетворение количеством тестовых заданий (в нашем случае 8) и согласились, что их должно быть значительно больше. Таким образом, преподавателю следует предложить свои формы контроля на определение уровня понимания, освоенности вводимых лексических единиц, грамматических структур. Отметим также, что визуализация материала служила толчком к развитию языковой догадки, а последующие языковые и коммуникативные задания из разделов “Think" и "Discuss" позволяют осуществлять самооценку и заставляют обращаться к видеофрагменту неоднократно.

\section{2. Социальные сети как инструмент дистанционного образования}


В связи с быстрыми изменениями в общественно-экономическом развитии многих стран в системе высшего образования, которая призвана готовить профессионалов своего дела, формируется заказ на расширенный состав компетенций и повышение уровня информационной культуры выпускников. Одной из важнейших образовательных целей становится формирование активной деятельностной позиции обучающихся по отношению к доступным им информационным ресурсам. Следует иметь в виду, что в уже 10 лет назад в статье С. Хилтона, Дж. Грэхэм, П. Ричи и Д. Уайтли, посвященной применению он-лайн технологий в обучении в аудитории и дистанционно доказывалось, что для изменения организации традиционного процесса помимо разработки плана занятий необходимо привлекать дополнительные ресурсы и знания, которые помогли бы определить время коммуникации, правил построения коммуникации в сети, создания дополнительных типов взаимодействия между обучаемыми онлайн и офлайн, определение зон ответственности между инструктором и преподавателем. Экспериментальная группа учащихся, находившихся в удалении, выразила мнение, что получили пользу от курса, особенно с точки зрения взаимодействия учащийся с содержанием [8, с. 81].

В самом начале карантина весной 2020 г. педагоги высшей школы столкнулись с проблемой, каким образом осуществлять взаимодействие со студентами, через какие интернет-ресурсы отправлять материалы для дистанционного обучения, как организовать взаимодействие наиболее эффективно. Как выяснилось, социальные сети сегодня являются одним из самых популярных сервисов, удерживающих внимание большей части интернет-аудитории. Поэтому их следует рассматривать в качестве инструмента для учебной работы с молодой аудиторией. Понятность идеологии и интерфейса социальной сети позволяет значительно сэкономить время, минуя этап адаптации учащихся к новому коммуникативному пространству. Применение в виртуальных учебных группах технологий форумов позволяет участникам самостоятельно или совместно создавать сетевой учебный материал: глоссарии, статьи, обсуждения, мультимедийные библиотеки и др.

Созданная в первые же дни карантина группа ВКонтаке «English for special purposes" стала сообществом студентов, обучающихся у одного и того же преподавателя по иностранному языку. На публичной странице можно было опубликовать материалы на английском языке из сферы научных научных предпочтений студентов, а также ссылки на видеоуроки в Youtube c 
презентацией грамматического материала. В ВКонтакте существует всего три типа группы. В «Открытую» группу могут вступить все желающие пользователи, в «Закрытую» - только по приглашению или после утвержденной заявки, а в «Частную» можно попасть только по приглашению руководителей. Поначалу наша сообщество было открытым, однако, обнаружился факт поступления спам продукции, картинки непристойного содержания, потому сообщество сделали закрытым. На вкладке «Участники» педагог-администратор мог посмотреть список всех участников сообщества. На вкладке «Ссылки» можно было добавить дружественные по тематике сообщества ресурсы, полезные по тематике материалы, например презентация "The periodic table of elements" [12]. Первые пять ссылок отражаются на главной странице группы. В сообщения сообщества преподаватель мог отправить информационную ссылку о созыве пресс-конференции в Zoom, ссылку на тесты, созданные в Приложении Google-forms и т.д. Заметим, что на своей странице, либо в группе ВК можно проводить опросы. Для этого нужно перейти к форме и нажать на ссылку «Еще». В выпадающем меню выбрать пункт «Опрос». В сообщество загружались файлы с текстами и заданиями по дополнительному профессионально-ориентированному чтению по тематике, коррелирующейся с программным материалом - Catalysis for coal conversion, Chemistry, The trials of new carbon, Nuclear power without radioactivity, Producing hydrogen from sea water, а также таблицы, аудифайлы к материалам учебника Кутеповой «The world of Chemistry". Студенты имели возможность в группе задавать интересующие их вопросы, обмениваться мнениями друг с другом и с преподавателем, присылали личными сообщениями аудиозаписи собственного голоса, выполненные задания (составление опорных схем для устного высказывания, план к прочитанной статье, упражнения и т.д.), выполненные в рамках индивидуального проекта презентации Power Point.

По результатам опроса обучаемых, проведенным в конце академического семестра выяснилось, что 62 \% использовали ВК до введения дистанционного обучения только преимущественно для обмена информацией, носящей развлекательный характер (обмен музыкой, личный чат, группы, связанные с хобби) и даже не предполагали, что социальная сеть может носить профессионально-образовательную функцию. Абсолютное большинство (92\%) высказались, что создание собственного проекта расширило познания не только в области отечественной истории, но и в области будущей профессиональной деятельности. 


\section{1. Роль страноведческие проектов в организации дистанционного} обучения

Одной из важнейших образовательных целей становится формирование активной деятельностной позиции обучающихся по отношению к доступным им информационным ресурсам. Такая позиция предполагает восприятие образовательных, общекультурных, профессиональных источников информации не только как предмета потребления для решения частных учебных задач, но и как средства развития, обеспечения успешности, конкурентоспособности в современном мире. В этом контексте особое значение приобретают навыки самостоятельного поиска и извлечения необходимых знаний, освоение перспективных способов применения их в различных ситуациях, навыков творческой и исследовательской деятельности в опоре на ресурсы обширной информационной среды $[3$, с. 44]. В этой связи актуализировалось использование проектной методики.

Страноведческие проекты, по мнению ряда исследователей, направленные в том числе на изучение исторических событий родного края, играют огромную роль в формировании поликультурной компетентности студентов, способствуя формированию представлений о целостности мира $[1, \mathrm{c}$. 107]. 2020 г. в России - год 75-летия победы над фашизмом. Мы, как педагоги, не могли остаться в стороне, поэтому родилась идея создания индивидуальных проектов по связанной с эти событием тематике. Среди предложенных студентам тем - «Russian chemical industry by the beginning of the 1940s (Состояние химической отрасли России к началу 1940-х гг.)», «The role of chemistry in the conduct of hostilities and the solution of tasks to ensure rear services (Роль химии в ведении военных действий и решении задач по обеспечению тыла)», «The contribution of the chemical scientists of Leningrad to the Great Victory (Вклад ученых-химиков г. Ленинграда в Великую победу)», «Development of explosives and fire retardant impregnations of wooden structures during the war (Разработки взрывчатых веществ и огнезащитных пропиток деревянных сооружений в годы войны)», -«The beginning of Great Patriotic War and the occupation of important regions of the country (Начало Великой Отечественной войны и оккупация важных районов страны)», «Research in the field of combustible lubricants and fuel during the Great Patriotic War (Исследования в области горюче смазочных материалов и топлива в годы Вов)», «Development of sanitary and therapeutic agents in the war years 1941-1945 (Разработки санитарных и лечебных средств в военные годы 1941-1945)», 
«Chemical science for production (fuel for military equipment (Химическая наука для производства (топливо для военной техники)», «Chemists and their contribution to defeating the enemy (Ученые-химики и их вклад в победу над врагом)», «Scientific developments in the field of medicines and sanitary preparations during the GPW. (Научные разработки в области лекарственных и санитарных препаратов в годы Вов)», «Institute of Organic Chemistry and the Development of Organic Chemists during the GPW. (Институт органической химии и разработки химиков-органиков в годы ВОв)», «The creation of polymer compositions and other compounds during the GPW (Создание полимерных составов и других соединений в годы ВОв)» и др. Безусловно, работа над индивидуальным проектом требует больших затрат времени и усилий, работа должна постоянно координироваться преподавателем, привлекаются онлайн ресурсы, создается собственный авторский текст с включением данных статистики, фактологического материала, делаются выводы. После определения содержания выступления по проекту необходимо было разбить его на смысловые части, выделить в каждой части главную, помещаемую на слайд информацию, сопровождаемую рисунками, документальными снимками, схемами. Педагог советовал, какие лексические единицы могут вызвать у аудитории затруднения и их следует поместить на слайде в постраничных и ссылках, переведя термин на русский язык.

Отдельная подгруппа студентов работала над совместным проектом "Tatarstan in the Great Patriotic War", в котором, соответственно, каждый занимался поиском материала по вверенной ему проблематике. Нами были разработаны и разосланы студентам критерии оценки презентации материала, касающиеся объема, содержания слайдов, указания на используемые источники, продолжительности устной презентации и т.д. Среди тем «Cultural construction in Tatarstan during the Great Patriotic War»; «Restructuring of industry and transport of the republic during the years of the Great Patriotic War»; «Evacuation hospitals in Tatarstan»; «Agriculture in Tatarstan in 1941-1945», «Airschools in Tatarstan" и др. В данном виде деятельности нашел свое отражение принцип междисциплинарного подхода к обучению, реализация которого позволяет студенту успешно овладевать общекультурными компетенциями и глубоко осмысливать профессиональные задачи, стоящие перед ним. Этап подготовки устного представления проекта требовал онлайн взаимодействия каждого студента с преподавателем в режиме видео-звонка или 
видеоконференции. Использовались платформы Zoom, a позднее Microsoft Teams.

Введенные в марте 2020 г. карантинные меры продемонстрировали необходимость создания не только собственных авторских онлайн ресурсов по преподаваемым дисциплинам, но и возможность творческого междисциплинарного подхода преподавателей к процессу обучения. Думается, что расширение возможностей дистанционного образования позволит систему образования сделать более гибкой, подстраивающейся под каждого обучаемого, дающей возможность студенту обучаться по собственной образовательной траектории.

\section{Список литературы}

1. Ишмурадова А.М., Евграфова О.Г. Страноведческие проекты как средство формирования поликультурной компетентности студентов на занятиях по иностранному языку // Современные исследования социальных проблем. - Красноярск: Научно-инновационный центр.- 2016. - №11-2 (67) C.106-110.

2. Медная Т.А. Междисциплинарность современного образования // Электронный вестник Ростовского социально-экономического института -2015 . - № 3 - 4 (июль - декабрь)

URL: https://cyberleninka.ru/article/n/mezhdistsiplinarnost-sovremennogoobrazovaniya

3. Носкова Т.Н., Павлова Т.Б. Взаимодействие с цифровыми ресурсами: продуктивность образовательной деятельности // Человек и образование - 2019 - №3 (60). - c.44-50.

4. Образцов П.И., Ахулкова А.И., Черниченко О.Ф. Проектирование и конструирование профессионально-ориентированной технологии обучения // Орел. - 2005. - 61 с.

5. Федеральный государственный образовательный стандарт высшего образования для направления подготовки 04.03.01Химия]. URL: http://fgosvo.ru/news/8/1107

6. Bilyalova A. ICT in Teaching a Foreign Language in High School // Procedia-Social and Behavioral Sciences. -2017 - №237 - P. 175-181

7. Evgrafova O., Ziganshina N. Implementation Of Ted (Technology, Entertainent, Design) Talks Content In Foreign Language Teaching // CSIS 2019 
11th International Scientific and Theoretical Conference "Communicative Strategies of Information Society" URL: https://www.researchgate.net/publication/ 339884701_Implementation_Of_Ted_Technology_Entertainent_Design_Talks_Cont ent_In_Foreign_Language_Teaching].

8. Graham C.R. , Hilton J., Rich P., Wiley D. Using Online Technologies to Extend a Classroom to Learners at a Distance // Distance Education - 2010.-№ 31(1). - P. 77-92.

9. “The danger of mixing drugs?” URL: https://www.ted.com/talks/ celine_valery_the_dangers_of_mixing_drugs]

10. "What is a coronavirus?" URL: https://www.ted.com/talks/ elizabeth_cox_what_is_a_coronavirus\#t-13731

11."When is a pandemic over?" URL: https://www.ted.com/talks/ alex_rosenthal_when_is_a_pandemic_over?utm_campaign=tedspread\&utm_medium =referral\&utm_source=tedcomshare],

12."The periodic table of elements" «https://presentacii.ru/presentation/Theperiodic-table-of-elements, ссылку на тест к учебнику «The world of chemistry" URL: $\quad$ https://www.teachnlearnchem.com/Video/World\%20of\%20Chemistry\% 20Notes/PDF/Episode\%207\%20-\%20The\%20Periodic\%20Table.pdf. 


\title{
УДК 37.02
}

\section{ОРГАНИЗАЦИОННО-ПЕДАГОГИЧЕСКИЕ УСЛОВИЯ РАЗВИТИЯ ДИСТАНЦИОННОГО ОБРАЗОВАНИЯ}

\author{
Рахмонов Азизхон Боситхонович \\ Доктор философии по педагогическим наукам $(\mathrm{PhD})$ \\ Узбекский государственный университет мировых языков
}

\begin{abstract}
Аннотация: в данной научно-исследовательской статье рассматривается организационно-педагогические условия развития дистанционного образования. Анализируются основные компоненты педагогического процесса, реализуемого посредством дистанционных образовательных технологий. Раскрывается сущность обусловленности дистанционного образования в высших образовательных учреждениях, также автора рассматривает роль функциональной модели в организации дистанционного образования.

Ключевые слова: педагогическое сопровождение, дистанционное обучение, социологическое сопровождение, социологическое сопровождение процесса, самообразовательная деятельность, деятельность, педагогический процесс, психическая ригидность, учебный элемент, вуз
\end{abstract}

Abstract: this research article examines the organizational and pedagogical conditions for the development of distance education. The main components of the pedagogical process implemented through distance education technologies are analyzed. The author reveals the essence of the conditionality of distance education in higher educational institutions, and also considers the role of the functional model in the organization of distance education.

Key words: pedagogical support, distance learning, sociological support, sociological support of the process, self-educational activity, activity, pedagogical process, mental rigidity, educational element, University

Анализ основных компонентов педагогического процесса, реализуемого посредством дистанционных образовательных технологий, позволяет выявить определенные «пробелы» в комплексе педагогических условий, необходимых для поддержки становления студента как субъекта учебно-профессиональной деятельности. Принципиальное значение имеют следующие из них [1]: 
- отсутствуют либо недостаточны условия для организации эффективного субъект-субъектного общения участников педагогического процесса;

- слабо представлены мыслетехнические, рефлексивные и другие компоненты, формирующие культуру интеллектуального труда и культуру организации учебно-профессиональной деятельности студента;

- оставлена без внимания «индивидуальная образовательная история» студента: не ведется работа по диагностике, которая рассматривается нами как разновидность педагогической поддержки.

Важнейшим условием развития ДО является создание необходимой психолого-педагогической базы, способствующей эффективности учебного процесса Что предполагает [2, с.126]:

- тщательное и детальное планирование деятельности студента, ее организация, четкая постановка задач и целей обучения;

- разработка учебно-методических материалов, опирающихся на психологические особенности восприятия, памяти, мышления, внимания, учет личностных особенностей студентов;

- наличие обратной связи между студентами и преподавателем, между студентом и учебным материалом;

- умение студентов самостоятельно работать с информацией.

Исследование учебной деятельности студентов традиционном очном обучении в настоящее время развивается в русле основных тенденций современных научных теорий познания. Усвоение уже накопленных теоретических знаний вплетается в процесс самостоятельного формулирования результатов индивидуального коллективного исследования, проектирования и конструирования, производимых в соответствии с требованиями различных форм познания, что и приводит студентов к уточнению научных понятий, к совершенствованию художественных образов, углублению нравственных ценностей и т.п. Учебная деятельность становится основой развития профессионально важных качеств, способствующих их будущей профессиональной деятельности.

Несмотря на существование отличий между традиционным и дистанционным обучением в психической организации студента как субъекта учения проявляются существенные черты сходства.

Современные информационные технологии образования ориентированы на вовлечение обучаемого в процесс активного освоения знаний. В психолого- 
педагогической литературе, посвященной проблемам использования компьютерных технологий, глубоко рассмотрены вопросы, связанные с их влиянием на психику человека и его развитие с принципами построения диалога между человеком и компьютером, с проблемами психологии компьютерного обучения [4, с.4].

Чрезмерная вовлеченность в работу с компьютером может обострять невротические черты личности, что при выраженной ее неуравновешенности может приводить человека к болезненному состоянию. Кроме позитивных или негативных эффектов, характеризующихся линейными связями между причиной и следствием, выделяют эффекты, в которых позитивные и негативные характеристики присутствовали одновременно, находясь в различных сочетаниях. Следовательно, при организации работы с компьютером и при разработке компьютерных технологий необходимо учитывать возможность возникновения позитивных и негативных последствий.

Как показали психолого-педагогические исследования и другие [5, с.74], большое значение в процессе обучения имеет внимание в плане формирования различного рода навыков: учебных, спортивных, трудовых, изобразительных и т.Д.

От состояния внимания зависит точность, скорость и полнота восприятия на всех его этапах, причем, ослабление внимания у индивида приводит к значительным нарушениям перцептивных процессов и искажениям формирующегося образа восприятия.

В мнемических процессах внимание оказывает влияние на скорость, точность, прочность запоминания и длительность сохранения заученного материала.

От состояния внимания зависит также эффективность мыслительной деятельности человека.

Внимание определяется как направленность и сосредоточенность психической деятельности человека. Под направленностью понимается избирательный характер этой деятельности и сохранение этой выбранной деятельности, под сосредоточением - углубление в данную деятельность и отвлечение от всего остального, не имеющего отношения» к деятельности.

Оно функционирует в сложном соотношении с многими проявлениями личности и находится в зависимости от ряда личностных факторов, например, наличия или отсутствия в структуре личности психической ригидности. 
Психическая ригидность не может быть рассмотрена как отдельная черта, существующая вне контекста личности. Рассматривая психическую ригидность как сложное, многомерное свойство личности, сочетающее в себе содержательную и формально-динамическую стороны, можно говорить, что внимание и психическая ригидность взаимосвязаны, и в рамках структурноуровневой концепции психики представляют собой линейные и нелинейные зависимости между разными уровнями регуляции.

Поэтому без создания специфической образовательной среды, построенной на учете вышеуказанных психолого-педагогических особенностей становится малоэффективно.

Развитие ДО происходит на базе разнообразных средств образовательных ресурсов - компьютерных обучающих программ, систем досок объявлений, виртуальных библиотек, телевизионных лекций. Это обстоятельство требует построения адекватной системы управления.

Управление в вузе понимается как постоянная деятельность по организации и координации деятельности участников образовательного процесса. Совместная деятельность субъектов в вузе как социальная система разворачивается в пространстве социальной организации, образуемом воздействием экономических, социальных, психологических, информационных и иных компонентов. Социальное управление процессом ДО - один из основных видов управления, главное предназначение которого заключается в обеспечении реализации потребностей развития образовательной системы и ее подсистем в виде реальных технологий обучения. Функция социального управления ДО в формировании критериев и показателей процесса обучения, выделении возникающих в нем социальных проблем, разработке и применении методов их решения, в достижении планируемых состояний и параметров социальных отношений и процессов. Оптимизация управления предполагает выбор наилучшего из всех возможных варианта управления.

Схема социальной управленческой структуры процесса ДО может быть представлена в виде трех социально-технологических компонентов. Первый субъектный компонент социально-управленческой структуры процесса ДО это вуз, предоставляющий комплекс услуг ДО. Второй объектный компонент обучающийся, потребитель этой формы образования. Наконец, третий компонент - собственно процесс обучения - представляет собой взаимодействие субъекта и объекта по поводу получения знаний. 
Достижение оптимального управления процессом ДО; в том числе социального, требует применения социологического сопровождения образовательного процесса дистанционной формы.

Необходимость системы социологического сопровождения высшего образовательного учреждения ДО обусловлена [6, с. 186]:

Во-первых, масштабами вуза.

Во-вторых, возрастанием роли вузов с ДО в системе подготовки специалистов высшей квалификации, и в «разработке этими вузами базы научно-технического обеспечения дистанционного образования и концепций развития образовательных систем.

В-третьих, внедрением ситуационной концепции в управлении, наиболее полно отвечающей целям и задачам вуза и предполагающей необходимость в социальном прогнозе и плане, которые могут дать важную информацию длясистемы управления вузом с ДО.

В связи с изменчивостью рыночной ситуации в образовании в целом, необходимостью наблюдения- за положением образовательной среды вуза и оценкой состояний ее подсистем работы по сбору, обработке, анализу социологической информации должны производиться постоянно (по определенным направлениям) и (или) с какой-то цикличностью (по другим направлениям).

В-четвертых, необходимостью учета возможности социальных рисков в деятельности вуза. Социальные риски возникают в связи с проблемами, которые выражаются в том, что вуз не достигает поставленных целей по причинам, связанным с недостаточным учетом человеческого фактора.

Особенность социологического сопровождения ДО вуза выражающаяся в определенной несогласованности между проводимыми локальными социологическими исследованиями и принятием социально ориентированных управленческих решений. Это вытекает из того, что сама система дистанционного обучения находится еще в становлении.

Непосредственной целью социологического сопровождения процесса дистанционного обучения является обеспечение органов управления высших учебных заведений и субъектов обучения необходимой социологической информацией для принятия управленческих решений, а также социологического обоснования способов решения проблем в сфере как самого процесса обучения, так и в сфере управления процессом ДО. Результатом 
социологического сопровождения является повышение эффективности процесса дистанционного обучения.

В прямой постановке понятие «социологическое сопровождение процесса ДО» в специальной литературе практически не рассматривается. В содержательном плане социологическое сопровождение процесса предполагает двухуровневую трактовку.

На первом уровне социологическое сопровождение рассматривается как часть или звено более широкого понятия - социологического обеспечения. С этой точки зрения социологическое сопровождение понимается как деятельность специально созданной структурной организации, связанная с отслеживанием и регулированием социального процесса.

На втором уровне социологическое сопровождение рассматривается как специфическая социальная технология, включающая в себя определенные технологические этапы.

Социологическое сопровождение процесса ДО - это система непрерывного использования социологического обеспечения в процессе обучения и обоснования социально-управленческих мероприятий в вуз

На первом уровне социологическое сопровождение процесса обучения рассматривают как деятельность специально создаваемого подразделения вуза (социологической службы), действующего в общей схеме управления системой обучения, с одной стороны, и получающего информацию о функционировании этой системы через соответствующую сеть (социологический актив филиалов и представительств) - c другой. Это подразделение также насыщает социологической информацией органы управления вузом.

Организация службы социологического сопровождения процесса дистанционного обучения предполагает несколько направлений работы: аналитико-диагностическое, просветительское, консультативное, методическое и прогностическое.

Для второго уровня социологическое сопровождение - это определенная социальная технология, которая включает широкий спектр мероприятий по методической подготовке, организации, проведению социологических исследований и анализу их результатов и выработке рекомендаций для управления высшим образовательным учреждением. Использование результатов исследований помогает в определении наиболее эффективных стратегий и тактик действия органов управления, в конструировании оптимальной образовательной среды. 
Модель социологического сопровождения процесса ДО представляют в виде совокупности последовательных этапов или блоков социальной технологии и деятельности специального подразделения вуза, неразрывно связанных между собой, взаимозависимых и согласованных по месту, времени, целям и задачам. Она предполагает реализацию выводов и рекомендаций системы социологического сопровождения на всех этапах управления вузом.

Сопровождение включает социологическую диагностику состояния социальных процессов в вузе и оценку динамики социального развития вуза, прогнозирование, проектирование, внедрение социальных мероприятий, планирование и контроль [6, с.197].

Под социологической диагностикой понимается - исследование реального состояния процесса дистанционного обучения, его структурных элементов. На этом этапе исследуется педагогическая, социальноэкономическая и социокультурная среда вуза, собирается необходимая информация о внешних и внутренних факторах деятельности вуза.

Социологическое прогнозирование - исследование перспектив и содержание проблем в деятельности вуза, их причины, способность вуза к решению данных проблем, осуществление прогноза деятельности по устранению несоответствия существующего состояния обучения предъявляемым требованиям преимущественно с количественными оценками и указанием определенных сроков их изменения.

Социологическое проектирование предполагает разработку научно обоснованного проекта процесса обучения, отвечающего требованиям нормативных документов, выработку и обоснование значений его основных параметров, определение наиболее приоритетных целей деятельности вуза. Модель выпускника вуза дается в контексте того, как, когда и в ходе какого процесса формируются ожидаемые качества выпускника.

Планирование - разработка системы, мероприятий, направленных на приведение в соответствие предъявляемым требованиям основных параметров процесса обучения. На данном этапе стратегические цели и задачи высшего» учебного заведения увязываются с его ресурсами - человеческими и материальными.

Внедрение - реализация прогноза проведения в жизнь системы мероприятий в рамках планируемого образовательного воздействия, выявление возможных конфликтов, узких мест, несогласованности в программе действий. 
Социологический контроль - система процессов и механизмов, обеспечивающих соответствие основных показателей, характеризующих действенность системы обучения, их заданным значениям.

Социологическое сопровождение предполагает осуществление процесса мониторинга образовательной системы высшей школы с целью выработки рекомендаций по управлению и приведению его в. оптимальную форму

Условиями развития образовательной самостоятельности являются $[7$, c.39]:

- управляемый характер самостоятельной работы студентов;

- системностью ее организации;

- продуктивный характер заданий;

- их достаточная индивидуализация;

- система контроля и самоконтроля.

Главными факторами, развивающими образовательность, является:

- отсутствие единого усреднённого темпа учения, что позволяет ускорить или замедлить его;

- выбор оптимального режима обучения, форм и места в использовании разнообразной среды учебы;

- применения множества форм индивидуальной самостоятельной работы - от персональных видеолекций, самостоятельного изучения учебных тем, а также овладения профессиональными навыками и умениями с помощью самообучающих и тренинговых компьютерных программ до различных видов активной работы. Эффективность развития образовательной самостоятельности обеспечивается использованием компонентов: телекоммуникационными и компьютерными средствами, организационнами формами, педагогическим процессом, квалификацией тьюторского состава как целостным образовательным процессом.

Важной задачей развития ДО является организация разноуровневой самостоятельной деятельности обучающихся. Ее содержанием выступает педагогическое сопровождение их предметной деятельности. В этом контексте компоненты педагогического сопровождения (диагностика, мотивация, контроль и оценка) «закладываются» в информационно-коммуникативном комплексе, разрабатываемом педагогом[8, с.12].

Педагогическое сопровождение должно создать условия для их развития. Можно установить, что сопровождение - самостоятельная новая функция педагога, а также же принять за основу определение этого понятия как метод, 
обеспечивающий создание условий для принятия субъектом развития оптимальных решений в различных ситуациях жизненного выбора. В основе этого метода лежит единство четырех функций: диагностики существа возникшей проблемы; информации о существе проблемы и путях ее разрешения; консультации на этапе принятия решения и выработки плана решения проблемы; первичной помощи на этапе реализации плана решения.

Сопровождение представляет собой взаимодействие сопровождающего и сопровождаемого, направленное на разрешение жизненных проблем последнего. Выданном определении термин «метод» объединяет все, что должен сделать педагог в сопровождении, так как метод - это и есть система действий. Здесь это система действий, обеспечивает взаимодействие. Кроме того, ценность представляют выделенные компоненты сопровождения: диагностика, информация, консультации, первичная помощь.

В исследованиях педагогическое сопровождение как деятельность педагога (тьютора) выступает необходимой поддержкой самообразовательной деятельности студентов. Реализуется оно в системном проектировании учебной и вспомогательной информации, возможных способов его усвоения, заданий для контроля и самоконтроля, средств и форм взаимодействия, предполагающих свободный выбор студента. Вместе с тем, самообразование как процесс глубоко личностный, поэтому его педагогическое сопровождение носит индивидуальный характер, особенно в условиях дистанционного обучения, и требует установления готовности студентов к такому образованию. Следовательно, системное проектирование информационно-коммуникативного компонента должно включать информационный блок, позволяющий установить степень готовности и одновременно сформулировать необходимый опыт самообразовательной деятельности.

Понятие педагогическое сопровождение в ДО рассматривается как метод взаимодействия педагога и студента в условиях асинхронности/синхронности и опосредованности их деятельности. Понятие сопровождение, его структурные компоненты, сущность ДО и самообразования, дают возможность построить модель педагогического сопровождения самообразования студентов в дистанционном обучении, как развертывание и практическое воплощение метода.

В данной модели педагогическое сопровождение предполагает процессуальное единство реализации мотивационного, проектировочного, конструктивного и организационного компонентов деятельности педагога. При 
этом сопровождение выполняет функцию побуждения к деятельности, ее поддержки в осуществлении самообразовательной деятельности студентов. Оно реализуется в следующих действиях педагога: актуализация содержания образования для каждой предметной области; диагностика готовности к самообразованию; разработка информационно-коммуникативного комплекса; разработка идентификационно-контрольного комплекса; оказание помощи и консультации. Оно детерминируется принципами дистанционного обучения и структурой самообразования [9, с.44].

Педагогическое сопровождение - это вариативно-содержательный алгоритм, реализующий взаимодействие педагога и обучающихся. Этот алгоритм определяется моделью дистанционного обучения, ведущими идеями и условиями обучения. Любая из моделей дистанционного обучения определяется технологией ее осуществления. Все определения характеризуют технологию как вид деятельности через такие термины как управление, конструирование, планирование, структурирование. Однако ни в одном определении не выделено, что любая технология становится ею тогда, когда деятельность может быть сознательно и планомерно расчленена и реализована в определенном порядке.

Рассматривают три уровня педагогических технологий: локальный, модульный и системный. Алгоритм разработки педагогических технологий включает пять последовательных шагов: аналитический, концептуальный, целевой, содержательный и процессуальный.

Анализ содержания понятия «педагогическая технология» позволил установить важные положения для моделирования педагогического сопровождения, в числе которых следующее: технология выступает механизмом управления образовательным процессом. Этому служит формализация и расчленение педагогического процесса с помощью управленческих процедур; признаками педагогической технологии является выделенный алгоритм, как процесс выделения этапов и их процедур, а также диагностичность цели каждого этапа.

Кроме того, структура самообразования требует такой системы действий педагога, которая направлена на создание условий для поддержания и развития мотивационного, операционального и волевого компонента. С точки зрения реализации в педагогическом сопровождении центральным компонентом является операциональный, включающий умения добывать, хранить и перерабатывать информацию. Качество представления этого компонента в 
педагогическом сопровождении влияет на развитие мотивационного и волевого компонентов. Уточнение необходимых условий для поддержания самообразования осуществлено на основе анализа технологий дистанционного обучения. В этих технологиях выделяются три основных блока: учебнометодический, средств обучения, блок взаимодействия и доставки учебных материалов.

Создание условий для самообразовательной деятельности в условиях дистанционного обучения означает разработку и реализацию учебнометодического комплекса, выбора средств и форм взаимодействия и обратной связи, разработку содержания и оценки вариативных видов контроля.

На основе теории управления и данных выводов, рассматривается функциональная модель педагогического сопровождения самообразования, которая включает 5 этапов[10, с.99]:

1) аналитико-целевой;

2) информационно-целевой;

3) коммуникативно-организационный;

4) консультативный;

5) контрольно-идентификационный.

Данные этапы представляют структуру педагогического сопровождения.

Посредством данной структуры педагогического сопровождения реализуется содержание обучения, осуществляется целенаправленная совокупность педагогических процедур, регулирующих, поддерживающих самообразовательный оперативный состав деятельности обучаемых, еe структуру и развитие. Содержание каждого этапа включает совокупность действий педагога, обеспечивающих реализацию функций дистанционного обучения и структурных компонентов самообразования, что является содержанием педагогического сопровождения. Педагогическое сопровождение разделяется на две стадии: подготовительную (1-2 этап) и организационную (34-5 этапы). Результатом подготовительной стадии является учебнометодический комплекс как информационная основа самообразовательной деятельности. Он включает: характеристику модульного блока и рекомендации по его усвоению; рекомендации по усвоению модулей; набор учебных элементов, соответствующих цели и содержанию' модулей; перечень основной и вспомогательной литературы; задания для итогового контроля; расписание консультаций непосредственных и опосредованных. Организационная стадия 
предполагает реализацию учебно-методического комплекса как средства взаимодействия.

Подготовительная стадия педагогического сопровождения была направлена на разработку учебно-методического комплекса и осуществлялась в соответствии с алгоритмом: анализ содержания образования и выбор идеи его структурирования; определение и анализ функциональных модульных блоков и целей их реализации; определение и анализ модулей и целей педагогического сопровождения; определение учебных элементов; формирование целей и тестов для учебного элемента; разработка проекта учебных элементов.

На весь период обучения сформулирована общая долгосрочная цель педагогического сопровождения, отражающая желаемый результат процесса овладения системой знаний и умений, формирования первоначального профессионального опыта, ценностного самоопределения будущего специалиста. В ходе этого процесса от одного модульного блока к другому реализуются конкретные цели, соответствующие общей долгосрочной цели и проявляются признаки их достижения. Эти цели относятся ко второму уровню и определяются как общие цели данного периода обучения. Их формулировка отражает в обобщенном виде содержания модульного блока.

Анализ содержания модульных блоков позволяет выделить содержательные единицы (модули), определить их структуру и содержание и сформулировать цели для каждого модуля в соответствии с целью модульного блока. Эти цели относятся к третьему уровню, как цель в общих терминах.

Все это характеризует второй шаг подготовительной стадии, в. которой действия, педагога направлены на выделение модулей, обеспечивающих готовность к профессиональной деятельности. Под модулем понимается» логически завершенный и далее неделимый блок учебной информации.

Заключает подготовительную стадию определение и разработка учебных элементов. Основным признаком для их выделения служит одно понятие или одно умение, либо их однородные совокупности.

Учебный элемент - самостоятельная учебная брошюра, включающая 4 определенный объем, учебной информации (теоретической или практической), предназначенной для обучения студента, ориентированного как на самостоятельную работу, так и на деятельность, осуществляемую под руководством педагога. Учебные элементы могут быть трех видов: инструкционно-технологические, теоретические, смешанные. 
Учебный элемент служит средством сопровождения самообразовательной деятельности, так как он включает описание целей, условий, содержания обучения, в виде пошаговой образовательной деятельности, а также рисунки, схемы, указания, по самоконтролю / и контрольный-тест.

Учебные элементы должны удовлетворять следующим требованиям [11, c.23]:

- обеспечивают основные компоненты самообучения (целевой, стимулирующе-мотивационный, содержательный, операциональнодеятельностный, контрольно-регулировочный, оценочно-результативный);

- учебная информация научно обоснована и содержит рациональные способы ее усвоения, логически завершена и представляет собой процесс усвоения последовательности: актуализация, осмысление, рефлексия и соответствует цели модуля;

- цель содержит три основных компонента: деятельность, усвоение, стандарт и идентифицируется, в действиях обучаемого с помощью глаголов повелительного' наклонения. Например: запишите, обобщите, перегруппируйте, поставьте вопрос и т. д.;

- включает список основной и вспомогательной литературы. Язык учебного элемента научный, конкретный и выразительный.

Таким образом, основой педагогического сопровождения самообразовательной деятельности в условиях дистанционного обучения является подготовительный этап. Содержание этого этапа определяет проектировочная и конструктивная функции педагога. Их реализация связана с анализом образовательного стандарта, на основе которого проектируется таксономия целей: общие долгосрочные, общие данного периода обучения, цели-модульных блоков, идентификационные целив учебных элементах. В соответствии с данной таксономией конструируется содержание самообучения как канва самообразования.

В рамках социологии процесс дистанционного обучения рассматривается как социальное взаимодействие обучающих и обучающихся с целью передачи и усвоения знаний с помощью высококвалифицированных преподавателей, современной техники, технических средств обучения и качественных учебнометодических материалов. Анализ взаимодействия в процессе ДО предполагает рассмотрение системы, социальных ролей, которые принимают на себя участники обучения, их статусов и поведенческих моделей, а также самой 
системы обучения и ее влияния на поведение и мотивацию обучаемых [12, c.59].

В учебном процессе вуза с ДО существенно повышается статус студента и возрастает его роль. Это обусловлено тем, что обучаемый активно строит свой учебный процесс. Важной функцией преподавателя становится поддержка его в деятельности и обеспечение активного взаимодействия обучаемого как с преподавателем, так> и с другими обучаемыми.

В этих условиях взаимодействие «один - многим», для которого характерно предоставление преподавателем учебного материала обучаемым, не играющим активной роли в коммуникации, на базе современных информационных технологий получает новое развитие.

Организационно решение задачи повышения эффективности социологического сопровождения может быть-реализовано с созданием социологической службы вуза Служба социологического сопровождения процесса ДО - это совокупность социологических подразделений вуза, осуществляющих сбор, анализ, распространение и активное внедрение в практику образовательной работы социологической информации по проблемам дистанционного обучения.

Служба социологического сопровождения процесса ДО предполагает несколько направлений работы: аналитикодиагностическое, просветительское, консультативное, методическое и прогностическое.

Для полноценного осуществления практической работы социологической службы вуза нужно создать специальные методические инструменты, соответствующие специфике решаемых задач.

В интерактивном взаимодействии социологическое сопровождение может проводиться в нескольких вариантах в зависимости от поставленной участниками образовательного пространства проблемы: как индивидуальное консультирование по переписке иди в диалоговом режиме; консультирование в режиме группового обсуждения, проводимое по заявленной проблеме в любой из форм ДО, и т.д.

Работа социологической службы в рамках ДО предполагает несколько вариантов организации в зависимости от конкретных задач, стоящих перед ней. Можно выделить две основные формы деятельности: по переписке, в чате, в непосредственном взаимодействии.

Социологическое сопровождение обеспечивает получение материалов по запросу студента или преподавателя, анализ содержания, социологические 
исследования, выработку рекомендаций. Телекоммуникационные возможности вуза позволяют использование новых технологий при сборе социологических данных: самозаполнение (анкетирование) респондентов х на компьютере, вопросник на компьютере, голосовая связь, электронная почта.,

Учет результатов социологического сопровождения закладывает информационные основания под разработку и составление планов менеджерской деятельности, способствует оптимизации управления вузом. Он позволяет конкретизировать содержание планируемых мероприятий, учесть направленность запросов и потребностей, осуществить рациональный выбор тех средств и форм работы, которые позволят выполнить намеченный план.

Социологические данные целесообразнее всего использовать при разработке перспективных комплексных планов, включаюпщх основные направления работы, ее средства, формы, и методы. В данном случае речь идет об использовании специальной группы социологических показателей, охватывающих качественно-количественные характеристики, которые описывают состояние объекта и результаты работы.

По мнению И.А. Крутий наиболее приемлемой является многоуровневая социологическая служба, с функциональным единым центром, методическим центром по разработке социальных технологий и сетью социологических подразделений в филиалах и представительствах [13, с.160].

Работа по развитию социологического сопровождения ведется в трех направлениях: исследовательском, аналитическом и административном. Административное направление обеспечивает проведение социологических исследований, решает все административные вопросы. Исследовательское планирует социологические исследования, разрабатывает необходимый методический инструментарий, обосновывает логику анализа эмпирической информации, изучает ее, готовит отчетность.

В ДО понятие «дистанция» предполагает не пространственную, удаленность, а дистанцию в плане отсутствия живого контакта, столь значительного с точки зрения педагогики. Что касается пространственной удаленности, то применение глобальных информационно-коммуникационных технологий приводит к исчезновению понятия «расстояние».

Поэтому важнейшим принципом приобщения к общечеловеческим ценностям является гармоничное сочетание традиционных и дистанционных форм обучения. 
В соответствии с этим принципом с целью эффективной реализации педагогической модели приобщения к общечеловеческим ценностям важно учитывать следующие педагогические условия [12, с.60]:

- наличие у студентов фиксированной, личностной установки на формирование отношений' человека к Миру, основанной на учениях этнопедагогики, теории и практики межкультурного образования (опора на лингвокультуроведческий анализ);

- индивидуализация дистанционного образования на основе учета психолого-возрастных особенностей студентов при помощи социометрической характеристики учебной группы и многофакторного опросника личности;

- активизация самостоятельной познавательной деятельности студентов, входе которой формируются умения приобретать и перерабатывать информацию.

Целенаправленное самообразование создает ситуацию востребованности сил саморазвития личности. В этом контексте педагогическое сопровождение рассматривается как создание условий для полноценного проявления, и раскрытия психо-физиологических возможностей обучаемого, которые проявляются в личностных функциях. В качестве таковых выделяются: избирательная; опосредующая, критическая, функция волевой саморегуляции, рефлексивная; смыслотворческая, ответственности за принимаемые решения и функция творческого преобразования и самореализации.

Тем самым в своем исследовании мы поставили задачу стимулирования интеллектуальной речемыслительной активности обучаемых и усиления учебной мотивации для реализации самостоятельной познавательной деятельности.

Таким образом, мы предположили, что первым необходимым педагогическим условием саморазвития личности учащихся и студентов в дистанционном обучении иностранному языку является активизация иноязычной речемыслительной деятельности. Развитие этого психолингвистического фактора, являющегося важным педагогическим условием саморазвития, компенсирует отсутствие непосредственного контакта в условиях ДО. Взяв за основу РМД положения вербальнокоммуникативной функции (ВКФ), реализующейся на основе других высших системных функций человека - мышления и памяти, и проанализировав различные подходы к их изучению, мы определили, что РМД активизируется на основе решения^ коммуникативных задач, включающих в себя постановку проблемных 
ситуаций, решение речевых задач, проектную методику, деловые игры. При этом ВКФ определяется как сложный механизм приема, переработки и выдачи вербальной информации посредством языка как средства и речи, как способа формирования и формулирования мысли во всех видах речевой деятельности в процессе общения.

\section{Список литературы}

1. Прокошев В.Г. Информационное и технологическое сопровождение региональной составляющей сервера «Образовательные ресурсы России» 164 // X Всероссийская научно-методическая конференция Телематика 2003. http://tm.inno.nl/tm2003/sect-b.php.

2. Сергиенко И.В. Организационно-педагогические модели дистанционного обучения в высшей школе. Монография: - Москва: Издво «МПА-Пресс», 2003. - 184 с.

3. Ваграменко Я.А. Общественная инициатива в решении задач информатизации образования // Информатизация образования-2003: Науч. тр. и материалы конф. АИО, Волгоград, 12-15 мая 2003 г. -М.; Волгоград: Перемена. - 2003 . - C. 3-8.

4. Дубровская Ю.А. Педагогические технологии в дистанционном обучении // Царскосельские чтения: Материалы международ, науч.-практ. конф. - 21 -22 апр., 2004. СПб., Т.Ш. - С. 32-34.

5. Серкова Н.В. Восприятие электронной информации в дистанционном обучении //Вестник Ассоциации «Открытый Университет Западной Сибири». Вып. 1. - 1999. - с. 71-74.

6. Крутий И.А. Роль социологического сопровождения в организации инновационного дистанционного обучения / Труды СГИ. - 2000. - Выл. 25.-С.182-196.

7. Леонов В.Г. Концептуальная модель дистанционного образования // Триместр - 1996 г., № 1 с. 36-41.

8. Пидкасистый П.И., Тыщенко 0.Б. Компьютерные технологии в системе дистанционного обучения // Педагогика. - 2000. - № 5. - С. 7-13. 
9. Дубровская Ю.А., Галышева А.С. Педагогическое сопровождение самообразования в условиях непрерывного образования // Образование через всю Ж!инь: Становление и развитие непрерывного образования в рамках единого образовательного пространства Евразийского экономического сообщесша: Материалы докладов участников конф. 244 с.

10. Зинченко В.П. Образование. Мышление. Культура //Новое педагогическое мышление. - М.: Педагогика, 1989. - с. 90-102.

11. Киселев Н.М. Теория, и практика освоения технологий управления в колледже по адаптации студентов // Сборник теория и практика управления учебными заведениями. - Оренбург, 1998. - с. 22-25.

12. Кугунуров В.В. Формирование личности в условиях дистанционного обучения межкультурной коммуникации // Проблемы формирования личности в современном ВУЗе: Сб. материалов республиканской межвузовской научнометодической конференции. - Якутск: Изд-во ЯГУ, 2001.-С.58-60.

13. Маркова А.К., Матис Т.А., Орлов А.Б.. Формирование мотивации учения: Кн. для учителя. - М.: Просвещение, 1990. - 192 с.

14. Кугунуров В.В. Формирование личности в условиях дистанционного обучения межкультурной коммуникации // Проблемы формирования личности в современном ВУЗе: Сб. материалов республиканской межвузовской научнометодической конференции. - Якутск: Изд-во ЯГУ, 2001.-С.58-60. 


\title{
Коллектив авторов
}

Барчо О.Ф., Береславская Н.В., Евграфова О.Г., Жигайлова Л.В., Ильичева В.А., Кузьминова Т.В., Лагунова Л.В., Лапп Е.А., Малоземов О.Ю., Огнева О.Г., Рамазнова Э.А., Рахмонов А.Б., Салимзанова Д.А., Сантуева Э.З.,Сахапова Ф.Х., Тронев В.В., Феталиева Л.П.

НАУЧНОЕ ИЗДАНИЕ

\section{СОСТОЯНИЕ, ПРОБЛЕМЫ, ПЕРСПЕКТИВЫ РАЗВИТИЯ СОВРЕМЕННОЙ НАУКИ И ОБРАЗОВАНИЯ}

\author{
Монография \\ Под общей редакцией \\ Козиловой Лидии Васильевны, \\ кандидата педагогических наук. \\ Подписано в печать 27.11.2020. \\ Формат 60x84 1/16. Усл. печ. л. 10,17. \\ Тираж 500 экз. \\ МЦНП «Новая наука» 185002 , г. Петрозаводск \\ ул. С. Ковалевской д.16Б помещ.35 \\ office@sciencen.org \\ www.sciencen.org
}

